\title{
Isotopic Power Materials Development Quarterly Progress Report for Period Ending March 31, 1976
}

A. C. Schaffhauser

\section{MASTER}

\section{OAK RIDGE NATIONAL LABORATORY}




\section{DISCLAIMER}

This report was prepared as an account of work sponsored by an agency of the United States Government. Neither the United States Government nor any agency Thereof, nor any of their employees, makes any warranty, express or implied, or assumes any legal liability or responsibility for the accuracy, completeness, or usefulness of any information, apparatus, product, or process disclosed, or represents that its use would not infringe privately owned rights. Reference herein to any specific commercial product, process, or service by trade name, trademark, manufacturer, or otherwise does not necessarily constitute or imply its endorsement, recommendation, or favoring by the United States Government or any agency thereof. The views and opinions of authors expressed herein do not necessarily state or reflect those of the United States Government or any agency thereof. 


\section{DISCLAIMER}

Portions of this document may be illegible in electronic image products. Images are produced from the best available original document. 
Printed in the United States of America. Available from

National Technical Information Service

U.S. Department of Commerce

5285 Port Royal Road, Springfield, Virginia 22161

Price: Printed Copy $\$ 5.00$; Microfiche $\$ 2.25$

This report was prepared as an account of work sponsored by the United States Government. Neither the United States nor the Energy Research and Development Administration/United States Nuclear Regulatory Commission, nor any of their employees, nor any of their contractors, subcontractors, or their employees, makes any warranty, express or implied, or assumes any legal liability or responsibility for the accuracy, completeness or usefulness of any information, apparatus, product or process disclosed, or represents that its use would not infringe privately owned rights. 
Contract No. W-7405-eng-26

METALS AND CERAMICS DIVISION

ISOTOPIC POWER MATERIALS DEVELOPMENT QUARTERLY PROGRESS

REPORT FOR PERIOD ENDING MARCH 31, 1976

A. C. Schaffhauser

JUNE 1976

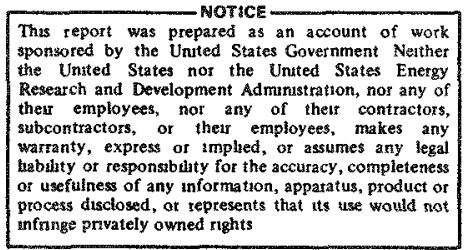

OAK RIDGE NATIONAL LABORATORY

Oak Ridge, Tennessee 37830

operated by

UNION CARBIDE CORPORATION

for the

ENERGY RESEARCH AND DEVELOPMENT ADMINISTRATION 


\section{FOREWORD}

This report is the second in a series of quarterly reports for Technology and Space Applications materials programs conducted by the Metals and Ceramics Division of Oak Ridge National Laboratory for the Nuclear Research and Applications Division of ERDA. These quarterly reports replace the monthly and annual reports previously issued on this work. The quarterly reports will provide a more detailed technical discussion of work in progress than was possible in the monthly reports. Significant technical highlights are reported to ERDA and their contractors on a monthly basis in the Technical Highlights of Isotopic Power Materials Development at Oak Ridge National Laboratory results, issued as CF memo reports, with limited distribution.

This quarterly report contains four chapters: (1) "High-Temperature Alloys for Space Isotopic Heat Sources," Activity No. KJ 300102 3, 189a No. 00001; (2) "Physical and Mechanical Metallurgy of Heat-Source Containment Materia1s," Activity No. KJ 300102 3, 189a No. 00002;

(3) "Isotope Brayton System Materials Support," Activicy No. KJ 300102 2, 189a No. 00006; and (4) "Space Nuclear Flight Systems Hardware," Activity No. KJ 3001032 , 189a No. 00003.

Recent previous reports covering work on these programs are listed below:

Isotopic Power Materials DeveZopment Quarterly Report

ORNL/TM-5285 Period Ending December 31, 1975

Isotopic Power Materials Annual Report

ORNL-TM-5116 Period Ending June 30, 1975

Isotopic Power Materials Development Monthly Reports

ORNL-TM-4859

January 1975

ORNL-TM-4890

February 1975

ORNL-TM-4918

March 1975

ORNL-TM-4953

Apri1 1975

ORNL-TM-4983

May 1975

ORNL-TM-5066

July 1975

ORNL-TM-5103

August 1975

ORNL-TM-5150

September 1975 
Copies of these reports are available from the U.S. Energy Research and Development Administration, Technical Information Center, P.0. Box 62, Oak Ridge, Tennessee 37830. 
CONTENTS

SUMMARY . . . . . . . . . . . . . . . . . . Vii

1. HIGH-TEMPERATURE ALLOYS FOR SPACE ISOTOPIC HEAT SOURCES . . . . . 1

1.1 Introduction . . . . . . . . . . . . . . . 1

1.2 Iridium Alloys . . . . . . . . . . . . . 1

1.2.1 Development of Improved Ir-0.3\% W Alloys . . . . . 1

1.2.2 Long-Term Grain Growth Studies of Iridium Alloys . . . . . . . . . . . 7

1.2.3 Development of Advanced Iridium Alloys with Dopants . . . . . . . . . 12

1.3 Pt-Rh-W Alloys . . . . . . . . . . . . 13

1.3.1 Pt-3008 Sca1e-Up and Fabrication Development . . . . 13

1.3.2 Welding of Pt-3008 Alloy . . . . . . . . 20

1.4 Ruthenium and Rhodium Alloys . . . . . . . . . . . . 22

1.4.1 Ruthenium Fabrication and Characterization ..... 22

1.5 References . . . . . . . . . . . . . . . 23

2. PHYSICAL AND MECHANICAL METALLURGY OF HEAT-SOURCE

CONTAINMENT MATERTALS . . . . . . . . . . . . 25

2.1 Introduction . . . . . . . . . . . . 25

2.2 Characterization of Impact Properties . . . . . . . . . 25

2.2.1 Impact Properties of Iridium Alloys . . . . . . 25

2.2.1.1 DOP-4 Dopant Effect . . . . . . . . 25

2.2.1.2 Thorium Concentration Effect . . . . . . 26

2.2.1.3 Impact Temperature Effect . . . . . . . 29

2.2.2 Effects of Long-Term Heat Treatment on Impact Properties of $\mathrm{Ir}-0.3 \%$ W Alloys . . . . . . . . 29

2.3 Environmental and Impurity Effects .......... . . . 34

2.3.1 Pt-3008 Air Oxidation ........... 34

2.3.2 Pt-3008/ $\mathrm{ZrO}_{2}$ Compatibility ......... 35

2.3.3 Pt-3008 Physical Properties .......... 38

2.4 Microanalysis Studies . . . . . . . . . . . 43

2.4.1 The Role of Thorium in $\operatorname{Ir}-0.3 \%$ W Alloys . . . . . . 43

2.4.2 Phosphorus Contamination and Embrittlement of

2.4.3 Grain Boundary Analysis of Pt-3008 Alloys . . . . . 50 
2.5 Special Projects . . . . . . . . . . . . . . . 50

2.5.1 Effects of Thermal Aging on the Mechanica1

Properties of Superalloys for Isotope

Containment . . . . . . . . . . . . . . . 50

2.5.1.1 Tensile Test Results on Inconel 625 . . . 51

2.5.1.2 Tensile Toughness of Superalloys . . . . . 51

2.5.1.3 Fractography of Fracture Surfaces and Identification of Phases . . . . . 54

2.5.1.4 Rationalization of Ductility and Toughness Results .......... 56

2.6 References . . . . . . . . . . . . . . . . 59

3. ISOTOPE BRAYTON SYSTEM MATERIALS SUPPORT . . . . . . . . . . . 61

3.1 Introduction . . . . . . . . . . . . . . . . . 61

$3.2 \mathrm{C}-103 /$ Gaseous Interactions . . . . . . . . . . . . . 61

3.3 Alternate Alloys . . . . . . . . . . . . . . . 65

3.4 Welding and Brazing Evaluation . . . . . . . . . . 65

3.5 References . . . . . . . . . . . . . . . . 66

4. SPACE NUCLEAR FLIGHT SYSTEMS HARDWARE . . . . . . . . . . . . 67

4.1 Introduction . . . . . . . . . . . . . . . . 67

4.2 Production of Ir-0.3\% W Forming Disks and Foil . . . . . . 67

4.2.1 Forming Disks ............... . 67

4.2.2 Foil ................... . 73

4.3 Impact Properties of Production Material . . . . . . . . 75 


\section{SUMMARY}

\section{HIGH-TEMPERATURE ALLOYS FOR SPACE ISOTOPIC HEAT SOURCES}

Continued studies of the beneficial effects of thorium additions to Ir $-0.3 \% \mathrm{~W}$ alloys show that, in terms of the mechanical properties at low strain rate, the $200 \mathrm{ppm}$ Th alloy (DOP-14) has optimum ductility and fracture behavior at $650^{\circ} \mathrm{C}$ (the fracture transition temperature). Results of grain growth studies at 1500 and $1800^{\circ} \mathrm{C}$ indicate that alloys containing 200-1000 ppm Th maintain a relatively fine grain microstructure after severe thermal exposure. Studies on the isolation of the important DOP-4 dopants show that aluminum, in addition to thorium, has a beneficial effect on the ductility, fracture transition, and grain growth behavior of iridium alloys. Long-term grain growth behavior of doped and undoped iridium alloys at $1300-1500^{\circ} \mathrm{C}$ for times to $2000 \mathrm{hr}$ show that, for the longer times and higher temperatures, grain growth of these alloys approaches the ideal grain growth law with an exponent of $-1 / 2$ for the number of grain boundaries across the cladding thickness as a function of time. Two advanced iridium alloys containing $2 \% \mathrm{Ru}$ with the DOP-4 dopants and $200 \mathrm{ppm}$ Th additions have been fabricated for evaluation.

Fabrication and inspection of sheet from the first consumable vacuumarc-melted scale-up ingot of the Pt-3008 alloy was completed, and $2.3 \mathrm{~kg}$ $(5.1 \mathrm{lb})$ of cold rolled sheet was supplied to LASL for impact capsules and compatibility studies and $1.4 \mathrm{~kg}(3.1 \mathrm{lb})$ was distributed to ORNL experimenters for mechanical property and welding studies. Chemical analysis indicates slightly higher levels of rhodium in sheets rolled from the nose and tail of the extrusion as compared to the central section. Trace impurities are within acceptable limits. Microstructural and recrystallization studies were completed. Consumable vacuum-arc melting of a second scale-up ingot weighing $8.35 \mathrm{~kg}(18.4 \mathrm{lb})$ was completed. Prealloyed melting stock for a $5.6-\mathrm{kg}(12.4-1 \mathrm{~b})$ commercial induction-melted ingot was also prepared. The room-temperature ductility of electron-beam and gas tungsten-arc welds in sheet from a small ingot of Pt -3008 annealed $1 \mathrm{hr}$ at $1200^{\circ} \mathrm{C}$ is $2 \% \mathrm{vs} 10^{\circ}$ in the base metal. A postweld heat treatment of $1 \mathrm{hr}$ at $1200^{\circ} \mathrm{C}$ increased the ductility of the electron-beam-welded specimens to $5 \%$, but showed no significant effect on the ductility of the gas tungsten-arc-welded specimen. 
Attempts to roll arc-melted and powder metallurgy ruthenium billets at $1300-1500^{\circ} \mathrm{C}$ were not successful due to formation of pinhole defects, possibly caused by the molybdenum cladding used for protection during rolling. Phase diagram studies confirm that the solubility of rhodium in ruthenium and ruthenium in rhodium is at least $20 \%$ as reported.

\section{PHYSICAL AND MECHANICAL METALLURGY OF HEAT-SOURCE CONTAINMENT MATERIALS}

Tensile impact tests of developmental doped iridium alloys at $1350^{\circ} \mathrm{C}$ and $85 \mathrm{~m} / \mathrm{sec}$ (280 fps) indicate that aluminum, in addition to thorium, is effective in improving the impact properties of $\mathrm{Ir}-0.3 \% \mathrm{~W}$ alloys. The alloys containing $40 \mathrm{ppm}$ Al plus $30 \mathrm{ppm}$ Th had about $27 \%$ elongation after annealing $19 \mathrm{hr}$ at $1500^{\circ} \mathrm{C}$ vs $15 \%$ for an alloy having no aluminum and $10 \%$ for an undoped material. Higher thorium additions also increased the ductility to $24 \%$ for the $100 \mathrm{ppm}$ Th alloy and 29\% for alloys containing 200-1000 ppm Th for the same test conditions. After a severe heat treatment at $1800^{\circ} \mathrm{C}$, the $200-1000$ ppm Th alloys are clearly superior having $25 \%$ ductility vs $14 \%$ for an a1loy containing $100 \mathrm{ppm} \mathrm{Th}, 11 \%$ for the DOP-4 alloy, and 2-5\% for the undoped material. The $200 \mathrm{ppm}$ Th alloy (DOP-14) also has better impact ductility at lower impact temperatures $\left(1050^{\circ} \mathrm{C}\right)$ : $29 \%$ vs $15 \%$ for DOP -4 and $5 \%$ for undoped material. The superior impact properties of the high-thorium alloys are due to second-phase particles which retard grain growth during hightemperature heat treatment. Long-term aging of tensile impact specimens of DOP-4 alloys and undoped iridium at $1330^{\circ} \mathrm{C}$ was continued. Impact tests at $1350^{\circ} \mathrm{C}$ and $85 \mathrm{~m} / \mathrm{sec}(280 \mathrm{fps})$ on specimens aged $1000 \mathrm{hr}$ confirm the continuing excellent impact ductility of the DOP-4 alloy as compared to undoped material (27\% vs $8 \%$ ). Extrapolation of the DOP-4 data indicates that this alloy may retain sufficient ductility ( $14 \%$ ) for operating times of 10,000 to $100,000 \mathrm{hr}$.

Oxidation tests on Pt-3008 tensile specimens scheduled for 10,000 hr have completed about $4000 \mathrm{hr}$ to date. After $3000 \mathrm{hr}$ of exposure at $600^{\circ} \mathrm{C}$, no weight change or effects on the tensile properties at $600^{\circ} \mathrm{C}$ were observed; however, at $800^{\circ} \mathrm{C}$, there was a weight gain due to the formation of an oxide film, and the tensile ductility at $800^{\circ} \mathrm{C}$ was reduced from 27 to $1.6 \%$. At $1000^{\circ} \mathrm{C}$ exposure, there was a weight loss and the ductility at $1000^{\circ} \mathrm{C}$ was $4.2 \%$. Pt -3008 compatibility specimens exposed to $\mathrm{ZrO}_{2}$ in vacuum 
and helium for $1000 \mathrm{hr}$ at $1050^{\circ} \mathrm{C}$ were tensile tested at 25 to $1316^{\circ} \mathrm{C}$. Specimens exposed to $\mathrm{ZrO}_{2}$ in vacuum had higher strength than control specimens at all test temperatures, possibly due to some reaction with $\mathrm{ZrO}_{2}$; however, there was no indication of embrittlement. Specimens exposed to $\mathrm{ZrO}_{2}$ in helium were significantly weaker than control specimens due to accelerated grain growth in the helium emvironment.

Additional Auger studies of grain boundary surfaces in $\mathrm{Ir}-0.3 \% \mathrm{~W}$ alloys with thorium additions to confirm that the segregation of thorium to concentrations of 3-5 at. $\%$ is independent of bulk thorium concentrations between 30-1000 ppm. Ion microprobe mass analysis of a cross section of the $1000 \mathrm{ppm}$ Th alloy showed that the second-phase particles are iridiumand thorium-rich. Auger analysis of an additional iridium sample from a FSA impact sphere showed 5 at. $\% \mathrm{P}$ on the grain boundary surface which was removed by inert ion sputtering less than 10 atom layers. Grain boundary analysis of several heats of Pt-3008 using Auger spectroscopy showed 0.5-1.5 at. $\% \mathrm{P}$ and up to 2 at. $\% \mathrm{Si}$; however, there was no correlation between the impurity segregation and the ductility minimum at $1093^{\circ} \mathrm{C}$.

Tensile tests at $24,316,760$, and $980^{\circ} \mathrm{C}$ on Inconel 625 specimens aged $11,000 \mathrm{hr}$ at $816^{\circ} \mathrm{C}$ were completed, complementing earlier tests conducted on Haynes 25, Haynes 188, and Hastelloy $N$ specimens. The results were interpreted with the aid of metallographic and electron probe analyses of internal microstructures, $x$-ray diffraction identification of phases, and electron-beam scans of fracture surfaces. Long-term aging at $816^{\circ} \mathrm{C}$ did not alter the yield and tensile strengths significantly; however, large changes in the ductility were observed. Whereas aging substantially depreciated ductilities for tests conducted at room temperature, tests at $760^{\circ} \mathrm{C}$ (region of the ductility minimum for solution-annealed condition) unexpectedly gave a substantial improvement in ductility. This improvement in ductility was reflected in very high fracture toughness values at $760^{\circ} \mathrm{C}(2-3$ times higher than at other temperatures) for the cobalt-base alloys. Aged Inconel 625 also gave high ductility and toughness at $760^{\circ} \mathrm{C}$ but, in addition, displayed high toughness at room temperature, being 2-3 times higher than for other alloys at this temperature. As a rule, high ductility is equated with intergranular fracture. The inversion of ductilities at $760^{\circ} \mathrm{C}$, brought about by overaging at $816^{\circ} \mathrm{C}$, is explained in terms of the secondary phases involved, how and when they precipitated, and their effects in depleting the matrix of tungsten. 


\section{ISOTOPE BRAYTON SYSTEM MATERIALS SUPPORT}

Work was initiated at the beginning of this quarter to determine the effects of potential gaseous impurities in the operating environment of the Brayton Isotope Power System (BIPS) on the mechanical properties of the C-103 alloy selected for the heat exchanger, hot ducting, and turbine plenum. Modification of an environmental creep apparatus to permit testing of $\mathrm{C}-103$ sheet specimens was completed. In the interim, the existing equipment was used to test tubular specimens of $\mathrm{T}-111$, which are chemically similar to $\mathrm{C}-103$. Tests at $1000^{\circ} \mathrm{C}$ and $15.2 \mathrm{MPa}(2.2 \mathrm{ksi})$ in an environment of $1.3 \times 10^{-3} \mathrm{~Pa}\left(1 \times 10^{-5}\right.$ torr $)$ air or carbon monoxide showed much higher strains than predicted from published vacuum creep data. Exposure of unstressed specimens to $1.3 \times 10^{-3} \mathrm{~Pa}\left(1 \times 10^{-5}\right.$ torr $)$ of oxygen at $1000^{\circ} \mathrm{C}$ resulted in a weight gain of $10,000 \mathrm{ppm}$ impurities in $100 \mathrm{hr}$ and produced a dilation of over $1 \%$.

The status of high-temperature bimetallic joint development was reviewed, and preparation specimens for long-term aging were initiated. Specimens are also being prepared to determine the mechanical properties of a recuperator braze alloy.

\section{SPACE NUCLEAR FLIGHT SYSTEMS HARDWARE}

Fabrication of iridium forming disks was suspended early in the quarter due to the detection of microscopic surface delaminations in metallographic certification samples. The defects were typically 0.1-mm (0.004-in.) long and less than $0.01 \mathrm{~mm}(0.0004 \mathrm{in.})$ below the ground surface. Investigations indicate that the most likely sources of the defects are the grinding, specimen cutting, and/or metallographic preparation operations. The defects have not been completely eliminated; however, additional testing showed no detrimental effects on the formability or impact ductility. Therefore, the nonconformance was accepted and fabrication was resumed. Only 18 of a scheduled 60 disks were shipped during this quarter; however, material in process is sufficient to meet Mound Laboratory's requirements with no slippage in the heat source assembly schedule.

Development of rolling procedures to cold rol1 $0.12-\mathrm{mm}-(0.005-\mathrm{in} .-)$ thick iridium foil in greater widths was completed using the doped iridium alloy. Approximately $1400 \mathrm{~cm}^{2}$ (210 in. ${ }^{2}$ ) was shipped to Mound Laboratory. 
Tensile impact tests at $1350^{\circ} \mathrm{C}$ and $85 \mathrm{~m} / \mathrm{sec}$ (280 fps) of a number of current production lots of forming disks show that the ductility after a $19 \mathrm{hr}$ at $1500^{\circ} \mathrm{C}$ heat treatment is reduced from about $21 \%$ in the first production lot to $16.5 \pm 2 \%$ in the fourth and sixth production lots. No detrimental effects of the microscopic surface delaminations were observed. The reduction in ductility is most likely due to the loss of aluminum dopants as the amount of recycled melting stock increases in the later production lots. However, the ductility of subsequent production lots should remain above $15^{\circ}$ (the ductility of a doped alloy with no aluminum). 


\section{HIGH-TEMPERATURE ALLOYS FOR SPACE ISOTOPIC HEAT SOURCES*}

\subsection{Introduction}

The objective of this program is to develop and qualify improved alloys for encapsulation of ${ }^{238} \mathrm{PuO}_{2}$ isotope fuels used for heat sources for high-temperature energy conversion systems for space and terrestrial power applications. We are developing a series of high-melting-point, noble-base alloys having the required mechanical properties, oxidation resistance, and stability in a heat-source environment under both operational and potential severe accident conditions. Our activities are divided between improved iridium alloys, Pt-Rh-W alloys, and lighter-weight ruthenium and rhodium alloys. Tasks on these materials include alloy and fabrication development, characterization, and supply of materials and hardware for qualification testing.

\subsection{Iridium Alloys}

1.2.1 Development of Improved Ir $-0.3 \% \mathrm{~W}$ Alloys $-\mathrm{C}$. T. Liu and H. Inouye

In order to study the effects of thorium content in the mechanical and metallurgical properties, Ir-0.3\% $\mathrm{W}$ alloys have been doped with different levels of thorium. Two new thorium-doped alloys containing 500 and 100 ppm Th, designated as DOP-21 and -22, were prepared and fabricated into sheets using the current production schedule. ${ }^{1}$ The tensile properties of DOP -21 and -22 and WTh-2 were determined at $650^{\circ} \mathrm{C}$ [at a crosshead speed of 2.54 $\mathrm{mm} / \mathrm{min}(0.1 \mathrm{in.} / \mathrm{min})]$ after a heat treatment of $1 \mathrm{hr}$ at $1500^{\circ} \mathrm{C}$. The tensile results are presented in Table 1.1 and are compared with WTh-1, DOP-14, and undoped WG. The thorium content in these alloys is also listed in Table 1.1. The yield strength of the alloys increases continuously with thorium content. The tensile strength also increases with thorium content to $500 \mathrm{ppm}$, but decreases at a level of $1000 \mathrm{ppm}$ (WTh-2). The DOP-21 alloy (doped with $500 \mathrm{ppm} \mathrm{Th}$ ) had a $240 \%$ higher yield strength and a $40 \%$ higher

\footnotetext{
*Progress on work performed under Activity No. KJ 3001023 , 189a No. 00001 .
} 
Table 1.1. Tensile Properties ${ }^{\mathrm{a}}$ of Doped and Undoped $\mathrm{Ir}-0.3 \% \mathrm{~W}$ Sheet Specimens ${ }^{\mathrm{b}}$ Tested at $650^{\circ} \mathrm{C}$

\begin{tabular}{|c|c|c|c|c|c|}
\hline \multirow{2}{*}{ Specimen } & \multirow{2}{*}{$\begin{array}{c}\text { Nomina1 Dopant } \\
\text { Concentration } \\
(\mathrm{ppm})\end{array}$} & \multicolumn{2}{|c|}{ Strength, $\mathrm{MPa}$ (psi) } & \multirow{2}{*}{$\begin{array}{c}\text { Elongation } \\
(\%)\end{array}$} & \multirow{2}{*}{ Fracture Mode ${ }^{c}$} \\
\hline & & Yield & Tensile & & \\
\hline WG-202 & None & $51.1(7,400)$ & $488.5(70,800)$ & 30.1 & Main1y GBS \\
\hline WTh-1 & $50 \mathrm{Th}$ & $72.5(10,500)$ & $536.8(77,700)$ & 39.2 & GBS (Ma) and TF (Mi) \\
\hline DOP -22 & $100 \mathrm{Th}$ & $77.9(11,300)$ & $551.2(80,000)$ & 38.5 & Mainly TF \\
\hline DOP -14 & $200 \mathrm{Th}$ & $96.6(14,000)$ & $609.1(88,400)$ & 41.5 & Mainly TF \\
\hline $\mathrm{DOP}-21$ & $500 \mathrm{Th}$ & $121.3(17,600)$ & $672.5(97,600)$ & 36.7 & $\mathrm{TF}(\mathrm{Ma})$ and $\mathrm{GBS}(\mathrm{Mi})$ \\
\hline WTh-2 & $1000 \mathrm{Th}$ & $126.1(18,300)$ & $594.6(86,300)$ & 27.0 & $\mathrm{TF}(\mathrm{Mi})$ and GBS (Ma) \\
\hline DOP -15 & $30 \mathrm{Th}, 80 \mathrm{Fe}$ & $77.9(11,300)$ & $507.1(73,600)$ & 40.1 & Mainly TF \\
\hline DOP -13 & $30 \mathrm{Th}, 40 \mathrm{~A} 1$ & $86.8(12,600)$ & $557.4(80,900)$ & 40.2 & Mainly TF \\
\hline DOP-16 & $30 \mathrm{Th}, 40 \mathrm{~A} 1,80 \mathrm{Fe}$ & $99.9(14,500)$ & $569.8(82,700)$ & 38.7 & Mainly TF \\
\hline$D O P-4(0.3 \% W)-10$ & $\begin{array}{l}30 \mathrm{Th}, 40 \mathrm{Al}, 80 \mathrm{Fe}, \\
16 \mathrm{Ni}, 75 \mathrm{Rh}\end{array}$ & $104.9(15,200)$ & $568.6(82,400)$ & 37.1 & Mainly TF \\
\hline
\end{tabular}

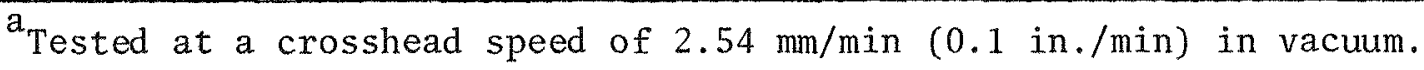

$\mathrm{b}_{\mathrm{All}}$ specimens annealed $\mathrm{l} \mathrm{hr}$ at $1500^{\circ} \mathrm{C}$ before testing.

${ }^{C_{\mathrm{GBS}}}=$ grain-boundary separation; $\mathrm{TF}=$ transgranular fracture; $\mathrm{Ma}=$ major fraction; and $\mathrm{Mi}=$ minor fraction. 
tensile strength than for the undoped alloy. The ductility also increases with thorium content and reaches a peak value of $41.5 \%$ at a level of $200 \mathrm{ppm}$ Th (DOP-14). The ductility drops considerably with more than $500 \mathrm{ppm}$ Th in the alloy.

The fracture surfaces of tensile specimens were examined by optical microscopy, and the results are also presented in Table 1.1. Alloying with thorium apparently strengthens the grain boundary and suppresses the grain boundary fracture. The alloys doped with 100 and $200 \mathrm{ppm}$ Th showed mainly transgranular fracture at $650^{\circ} \mathrm{C}$, while the undoped alloy showed mainly grain-boundary separation. However, the alloys doped with 500 and $1000 \mathrm{ppm}$ Th exhibited mixed fracture modes at $650^{\circ} \mathrm{C}$, and the propensity for grainboundary separation increases with thorium content. Thus, in terms of fracture behavior, the optimum amount of thorium in the $\operatorname{Ir}-0.3 \% \mathrm{~W}$ alloy should be around $200 \mathrm{ppm}$.

The microstructure of the thorium-doped alloys was examined metallographically after short-term heat treatments at 1500 and $1800^{\circ} \mathrm{C}$. The microstructures are shown in Figs. 1.1-1.3. The heat-treated specimens show a recrystallized structure with second-phase particles, probably $\operatorname{ThIr}_{5},(\operatorname{Ref} .2)$ within the grains and on grain boundaries. The amount of second-phase particles increases with thorium content, and some particles actually line up into stringers in the $1000 \mathrm{ppm}$ Th a11oy [Figs. 1.1(d), 1.2(d), and 1.3(d)]. We believe this causes the low ductility of WTh-2 at $650^{\circ} \mathrm{C}$ (see Table 1.1). The grain growth resistance increases with thorium content, particularly after a complex heat treatment at $1800^{\circ} \mathrm{C}$ (Fig. 1.3). The refinement of grain structure is apparently due to the presence of second-phase particles which pin the grain boundary and retard its growth.

Characterization of impact behavior of $\operatorname{Ir}-0.3 \% \mathrm{~W}$ alloys indicates ${ }^{3}$ that both the grain size and fracture behavior at $650^{\circ} \mathrm{C}$ affect the impact properties of this alloy. Concern of both factors suggests that, in terms of impact properties alone, the optimum amount of thorium in $\operatorname{Ir}-0.3 \% \mathrm{~W}$ alloys should be somewhere between $200-500 \mathrm{ppm}$. The tensile impact properties of the thorium-doped alloys are reported in the "Physical and Mechanical Metallurgy of Heat-Source Containment Materials" chapter (chapter 2 of this report). 

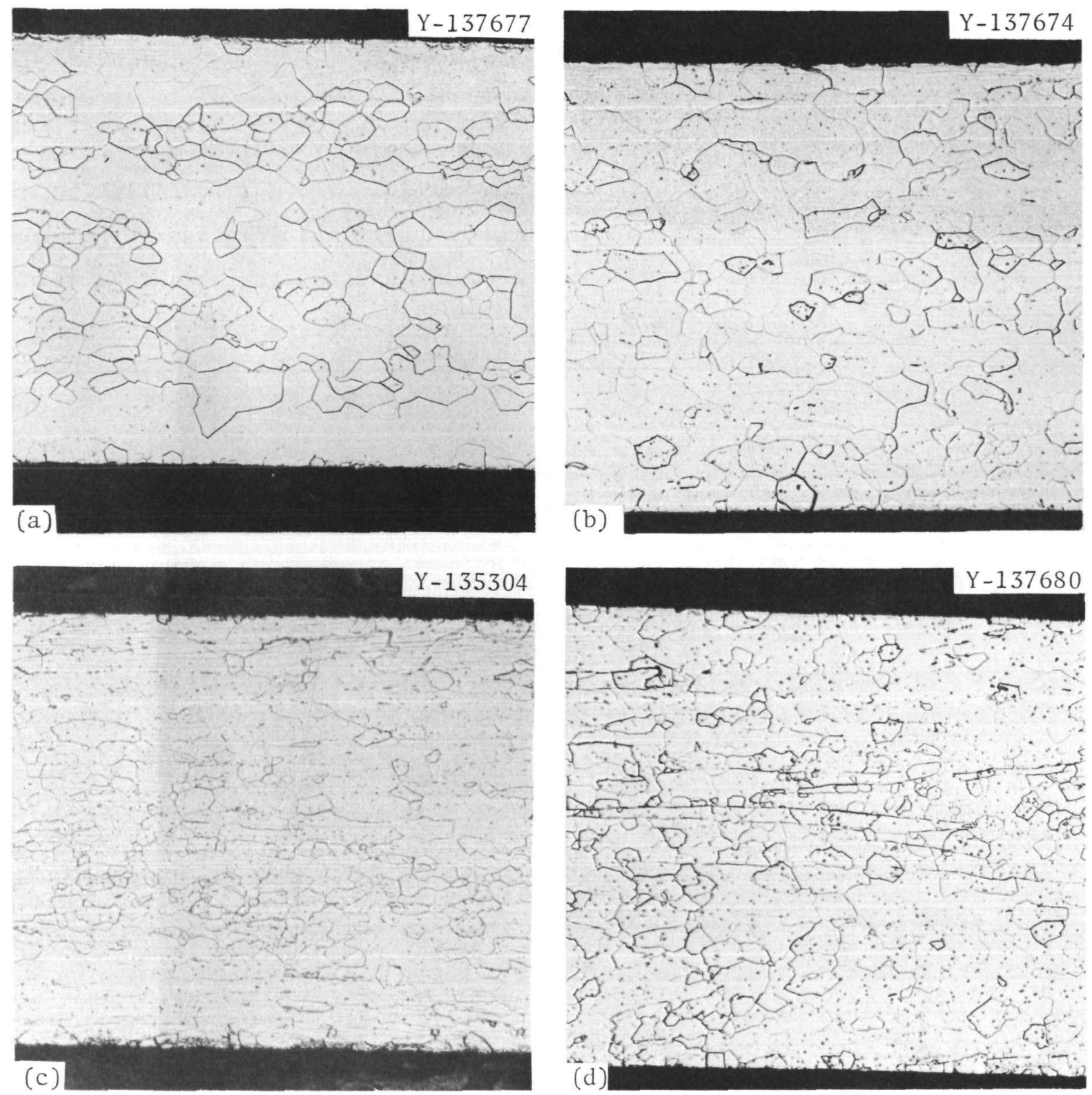

Fig. 1.1. Microstructures of $\operatorname{Ir}-0.3 \% \mathrm{~W}$ Alloys Doped with Various Levels of Thorium: (a) WTh-1, $50 \mathrm{ppm}$ Th; (b) DOP-22, $100 \mathrm{ppm}$ Th; (c) DOP-14, $200 \mathrm{ppm} \mathrm{Th;} \mathrm{(d)} \mathrm{WTh-2,} 1000 \mathrm{ppm}$ Th. (Heat treatment for all alloys: $1 \mathrm{hr}$ at $1500^{\circ} \mathrm{C}$.) $100 \times$. 

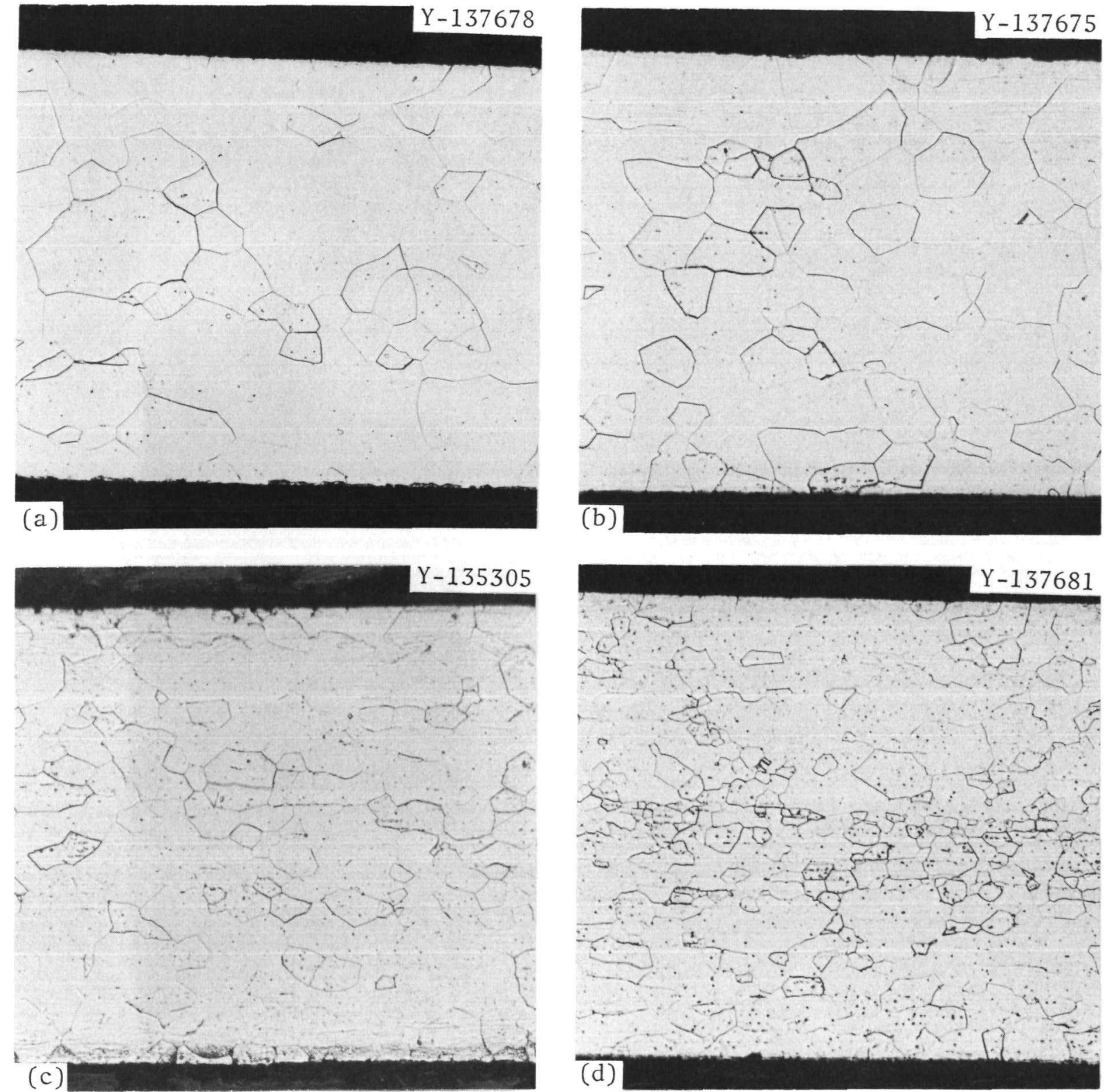

Fig. 1.2. Microstructures of Ir-0.3\% W Alloys Doped with Various Levels of Thorium: (a) WTh-1, $50 \mathrm{ppm}$ Th; (b) DOP-22, $100 \mathrm{ppm}$ Th; (c) DOP-14, $200 \mathrm{ppm} \mathrm{Th;} \mathrm{(d)} \mathrm{WTh-2,} 1000 \mathrm{ppm}$ Th. (Heat treatment for a11 alloys: $19 \mathrm{hr}$ at $1500^{\circ} \mathrm{C}$.) $100 \times$. 

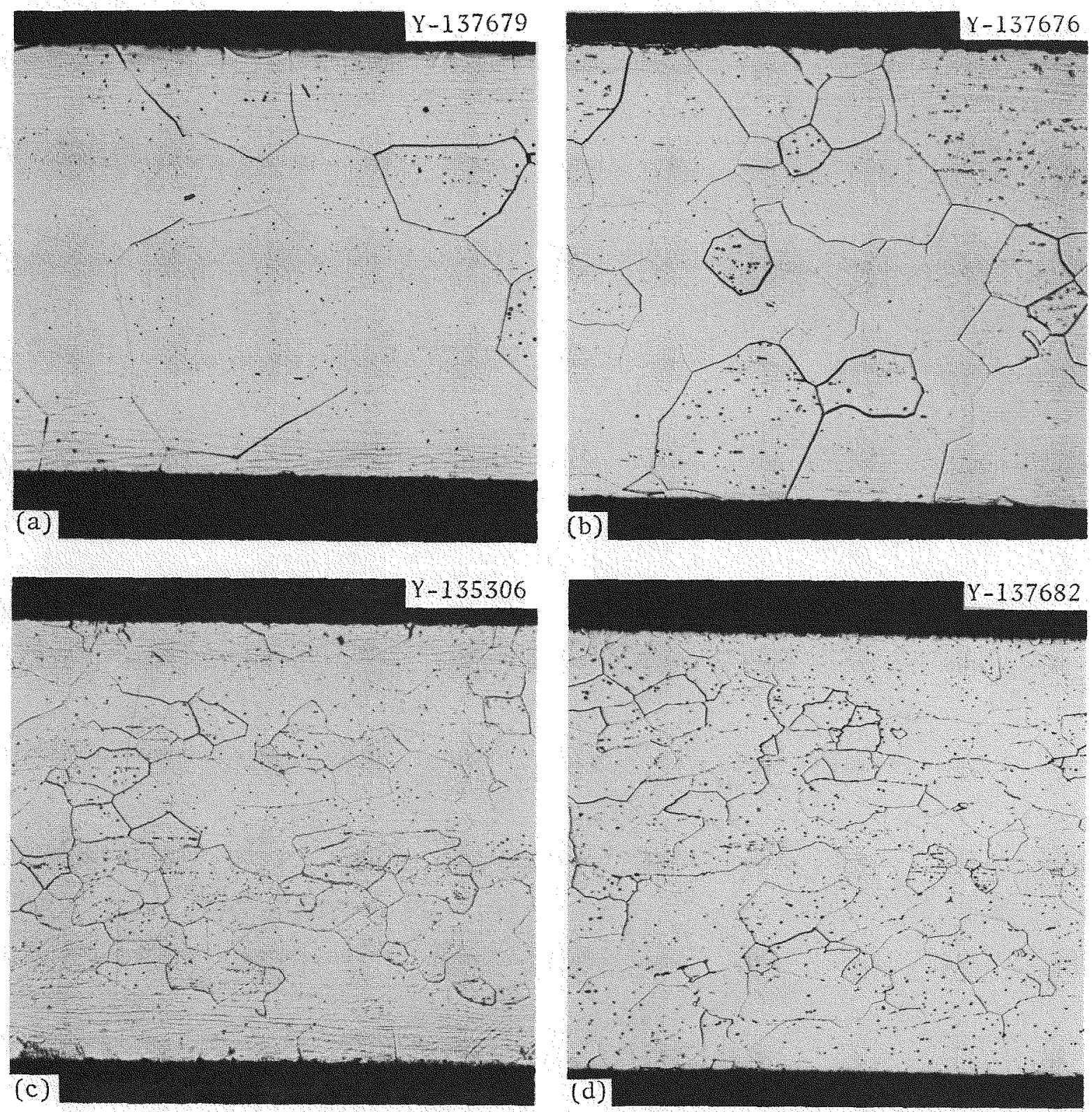

Fig. 1.3. Microstructures of Ir-0.3\% W Alloys Doped with Various Levels of Thorium: (a) WTh-1, $50 \mathrm{ppm}$ Th; (b) DOP-22, $100 \mathrm{ppm}$ Th, (c) DOP-14, 200 ppm Th; (d) WTh-2, $1000 \mathrm{ppm}$ Th. (Heat treatment for all alloys: $1 \mathrm{hr}$ at $1500^{\circ} \mathrm{C}+1 \mathrm{hr}$ at $1800^{\circ} \mathrm{C}+1 \mathrm{hr}$ at $1500^{\circ} \mathrm{C}$.) $100 \times$. 
To identify the important dopants in DOP-4, three new alloys (DOP-13, -15 , and -16), with different combinations of aluminum and iron additions with thorium (dopant concentrations listed in Table 1.1), were prepared and fabricated into $0.76-\mathrm{mm}-(0.30-\mathrm{in} .-)$ thick sheets. ${ }^{3}$ The tensile properties of these doped alloys were determined at $650^{\circ} \mathrm{C}$ after a heat treatment of $1 \mathrm{hr}$ at $1500^{\circ} \mathrm{C}$. The results are presented in Table 1.1 and are compared with DOP-4 $(0.3 \% \mathrm{~W})-10$ and undoped WG. Doping with $40 \mathrm{ppm} \mathrm{A1}$ and/or $80 \mathrm{ppm} \mathrm{Fe}$, in addition to $30 \mathrm{ppm} \mathrm{Th}$, increases the yield and tensile strengths of the Ir-0.3\% $\mathrm{W}$ alloys. Aluminum appears slightly more effective in strengthening. The alloys doped with DOP-4 series of dopants had tensile elongation in the range $37-40 \%$. A11 the alloys doped with DOP-4 series of dopants showed transgranular fracture at $650^{\circ} \mathrm{C}$. The tensile impact properties of these alloys are reported in chapter 2 of this report.

Figure 1.4 compares the microstructures of DOP-13 (30 ppm Th, $40 \mathrm{ppm}$ A1) and DOP-15 (30 ppm Th, $80 \mathrm{ppm} \mathrm{Fe)} \mathrm{to} \mathrm{rationalize} \mathrm{the} \mathrm{effect} \mathrm{of} \mathrm{aluminum}$ and iron on grain structures. After a 1 -hr anneal at $1500^{\circ} \mathrm{C}$, the DOP-13 specimen showed distinctly elongated grain structure while DOP-15 exhibited, more or less, an equiaxed grain structure. In terms of number of grains across the specimen thickness, DOP-13 had 23.9 as compared to 15.6 for DOP-15. The DOP-13 alloy had a finer grain structure evan after the 19-hr anneal at $1500^{\circ} \mathrm{C}$ [Fig. 1.4(c) and (d)]. Thus, doping with 40 ppm A1 has distinct effects in the grain structure of the $\operatorname{Tr}-0.3 \% \mathrm{~W}$ a11oy.

\subsubsection{Long-Term Grain Growth Studies of Iridium Alloys - D. E. Harasyn}

The results of the grain growth study on $\mathrm{Ir}-0.3 \% \mathrm{~W}$ alloys are shown in Figs. 1.5, 1.6, and 1.7. The study included three alloys (undoped WER and WG batches and the DOP-4 a1loy) heated at 1310,1415 , and $1530^{\circ} \mathrm{C}$ for times to $2000 \mathrm{hr}$. These data show little difference in grain size between WG and WER for almost any given time and temperature. A spot check of WC and WE alloys (earlier PICS production material) shows little difference from WG and WER alloys. The grain size of DOP-4 is always smaller than WG and WER at al1 times and temperatures shown. The curves approach a slope of $-1 / 2$ at the larger grain sizes (i.e., longer time or higher temperature). Such behavior is expected for alloys that obey the ideal grain 

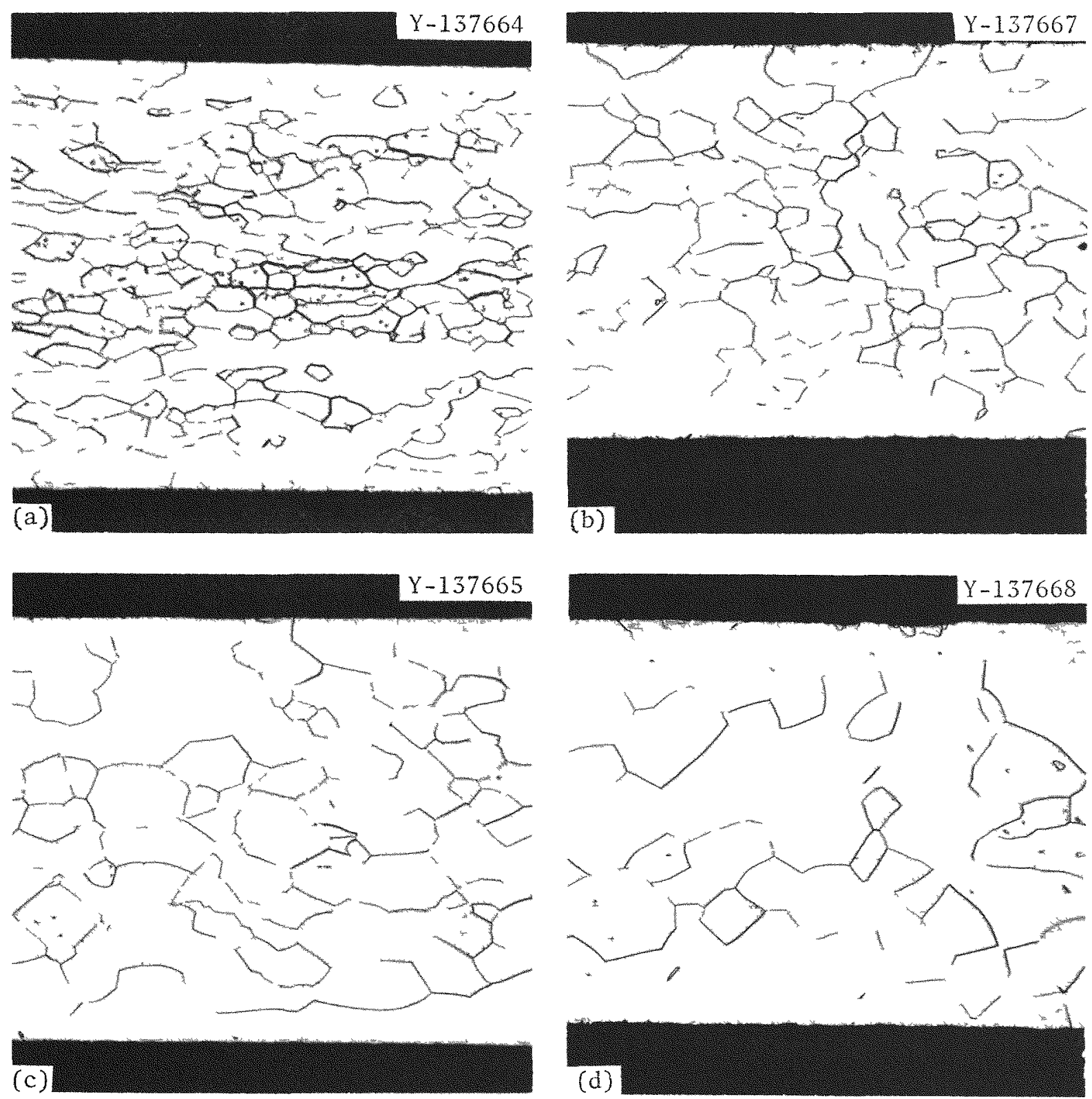

Fig. 1.4. Microstructures of Doped Ir-0.3\% W Alloys: (a) DOP-13 (30 ppm Th, $40 \mathrm{ppm} \mathrm{Al}$ ), Heat Treatment of $1 \mathrm{hr}$ at $1500^{\circ} \mathrm{C}$; (b) DOP -15 (30 ppm Th, $80 \mathrm{ppm} \mathrm{Fe}$ ), Heat Treatment of $1 \mathrm{hr}$ at $1500^{\circ} \mathrm{C}$; (c) DOP -13 , Heat Treatment of $19 \mathrm{hr}$ at $1500^{\circ} \mathrm{C}$; and (d) DOP-15, Heat Treatment of 19 hr at $1500^{\circ} \mathrm{C}$. $100 \times$. 


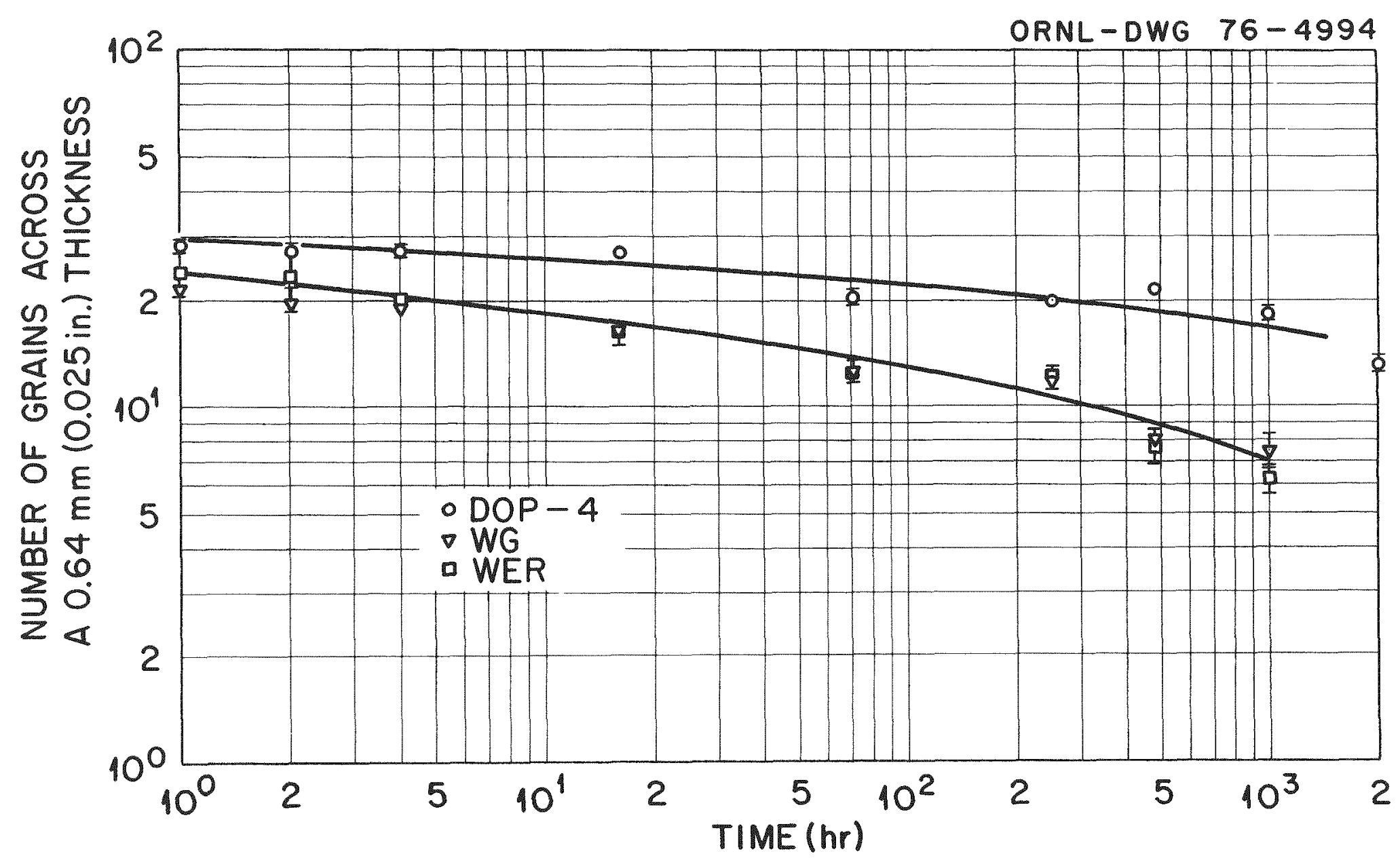

Fig. 1.5. Number of Grains Across a $0.64-\mathrm{mm}-(0.025-$ in.-) Thick Ir-0.3\% W Alloy Sheet vs Annealing Time at $1310^{\circ} \mathrm{C}$. 


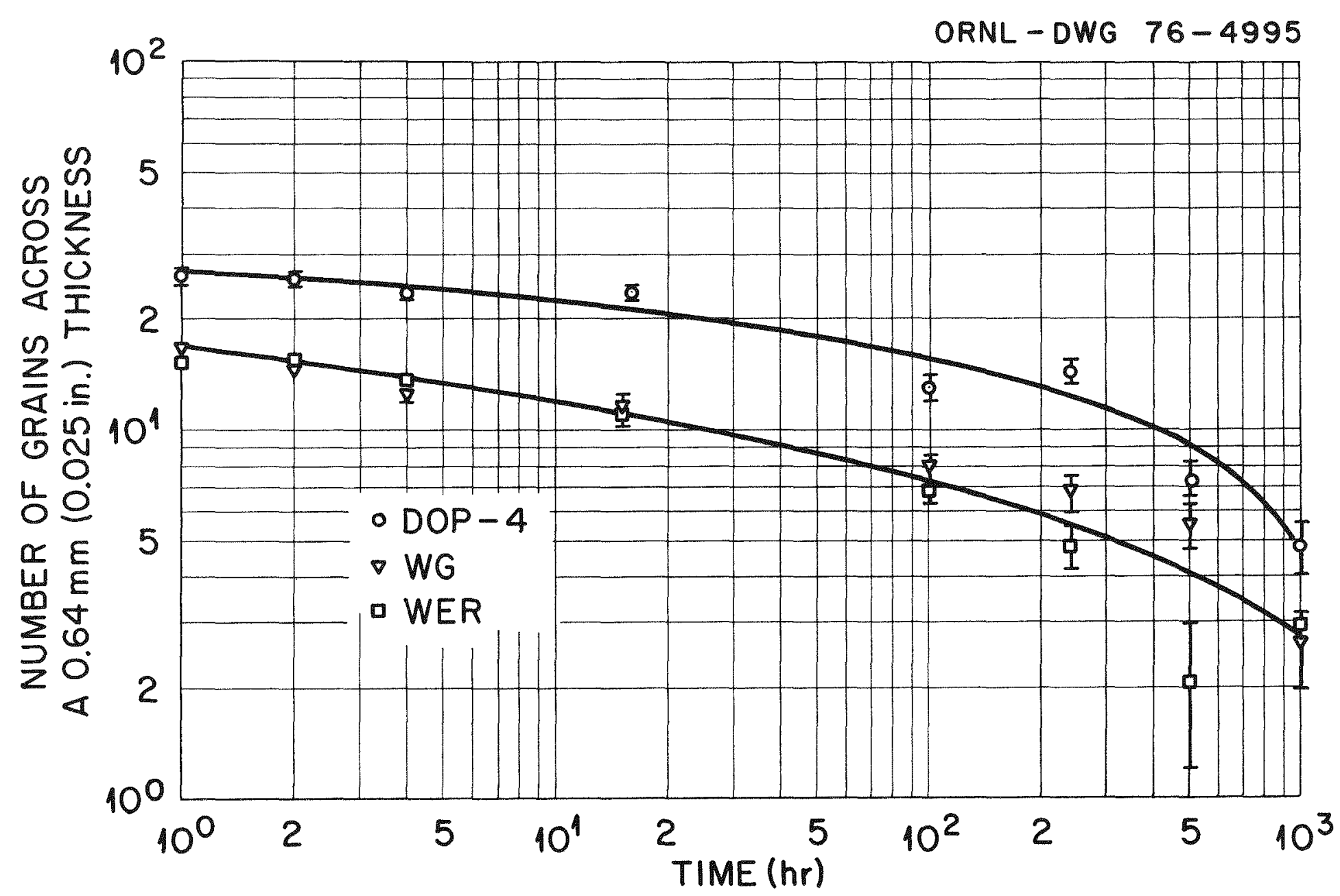

Fig. 1.6. Number of Grains Across a $0.64-\mathrm{mm}-(0.025-$ in.-) Thick Ir-0.3\% W Alloy Sheet vs Annealing Time at $1415^{\circ} \mathrm{C}$. 


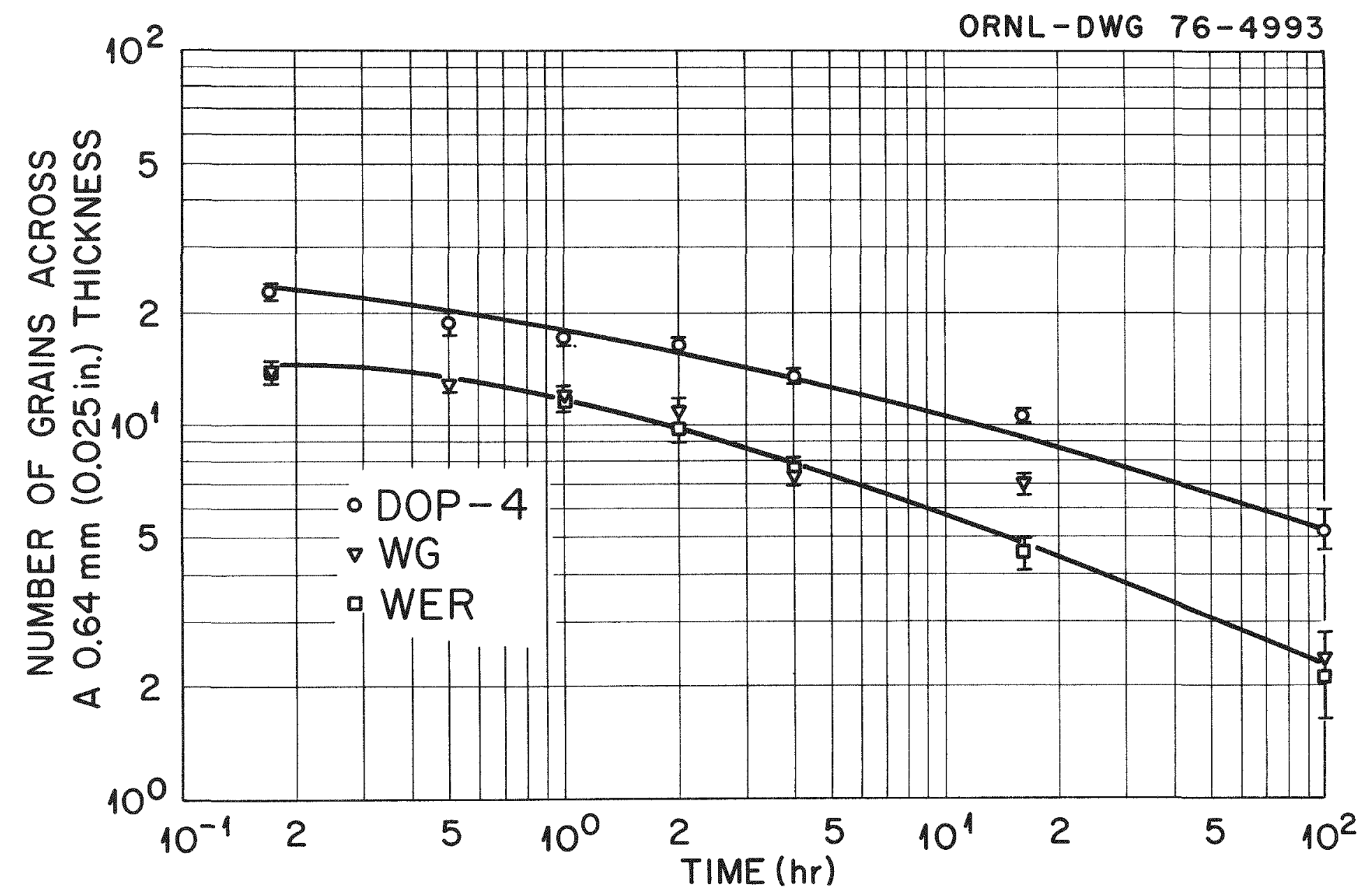

Fig. 1.7. Number of Grains Across a 0.64-mm- (0.025-in.-) Thick Ir-0.3\% W A1loy Sheet vs Annealing Time at $1530^{\circ} \mathrm{C}$. 
growth law. We will try to fit the data to the grain growth law and, if possible, determine an activation energy.

The error bars shown in Figs. 1.5, 1.6, and 1.7 represent the standard deviation of the average number of grains across a $0.64-\mathrm{mm}(0.025-\mathrm{in}$.) thickness. They are not a measure of the reproducability of the data but simply an indication of how closely the average value could be determined for an individual sample.

We are continuing our long-term grain growth studies on the doped iridium alloys at $1330^{\circ} \mathrm{C}$. The data for samples aged to $2000 \mathrm{hr}$ are summarized in Table 1.2. The Ir-0.3\% $\mathrm{W}$ alloys containing 200 and $1000 \mathrm{ppm} \mathrm{Th}$ are much more resistant to long-term grain growth, with 5 to 7 times more grain boundaries across the sheet thickness after $980 \mathrm{hr}$ at $1330^{\circ} \mathrm{C}$ as compared to the undoped alloys, and 2 to 3 times that for the DOP -4 alloy after $2000 \mathrm{hr}$ at $1330^{\circ} \mathrm{C}$

Table 1.2. Grain Size Data for Ir-0.3\% W Alloys Heat Treated at $1330^{\circ} \mathrm{C}$

\begin{tabular}{|c|c|c|c|c|c|c|c|}
\hline \multirow[t]{2}{*}{$\begin{array}{c}\text { Alloy } \\
\text { Designation }\end{array}$} & \multirow{2}{*}{$\begin{array}{l}\text { Amount Thorium } \\
\text { Added to Melt } \\
\text { (ppm) }\end{array}$} & \multicolumn{6}{|c|}{$\begin{array}{c}\text { Number of Grain Boundaries } \\
\text { Across a } 0.64-\text { mm } \\
(0.025-i n .) \text { Thickness }\end{array}$} \\
\hline & & $480 \mathrm{hr}$ & $\mathrm{SD}^{\mathrm{a}}$ & $980 \mathrm{hr}$ & $S D^{a}$ & $2000 \mathrm{hr}$ & $S D^{a}$ \\
\hline WER & 0 & 7.8 & 0.4 & 6.3 & 0.4 & - & - \\
\hline$W G$ & 0 & 8.0 & 0.5 & 7.5 & 0.6 & - & - \\
\hline DOP-4 & 30 & 21.5 & 0.7 & 18.3 & 0.6 & 13.5 & 0.6 \\
\hline DOP-14 & 200 & 34.3 & 0.5 & 31.5 & 0.8 & 30.3 & 1.0 \\
\hline WTh-2 & 1000 & 49.7 & 0.7 & 44.4 & 1.1 & 42.2 & 1.0 \\
\hline
\end{tabular}

${ }^{\mathrm{a}}$ Standard deviation of the average, based upon 12 measurements.

\subsubsection{Development of Advanced Iridium Alloys with Dopants - C. T. Liu}

Previous work in advanced iridium alloys indicates that $\mathrm{Ir}-2 \% \mathrm{Ru}$, $\operatorname{Ir}-1.92 \% \mathrm{~W}$, and $\operatorname{Ir}-0.3-0.6 \% \mathrm{Hf}$, have the most promising properties in terms of oxidation resistance, tensile properties, recrystallization, and grain growth behavior. However, our tensile tests reveal that alloying iridium with these elements does not improve grain boundary strength or suppress grain-boundary separation. In an attempt to further improve their mechanical properties, we have added dopants ${ }^{1}$ to these alloys. 
Two doped, advanced alloys were prepared by arc melting and drop casting into $19.05 \times 19.05 \times 38.10-50.80 \mathrm{~mm}(3 / 4 \times 3 / 4 \times 11 / 2-2$ in. $)$ ingots. One of the alloys is Ir-2\% Ru-0.3\% W doped with $200 \mathrm{ppm}$ Th (DOP-17); the other is $\operatorname{Ir}-2 \% \mathrm{Ru}-0.5 \% \mathrm{~W}$ doped with DOP-4 dopants (DOP-18). The starting material for these ingots was electron-beam melted and the dopants were added as arc-melted master alloys. Because of some difficulty in casting the DOP-18 alloy, it took 4 attempts at drop casting to get a sound ingot. However, there was no difficulty in drop casting the DOP-17 a11oy. The ingots were then clad in molybdenum and fabricated into $0.76-\mathrm{mm}-(0.030-$ in.-) thick sheets between 1200 and $1100^{\circ} \mathrm{C}$. The evaluation of their properties is in progress.

\subsection{Pt-Rh-W Alloys}

\subsubsection{Pt-3008 Scale-Up and Fabrication Development - M. M. Martin}

Fabrication of Pt-3008 (Pt-30\% Rh-8\% W) sheets for LASL and ORNL qualification studies continues. Progress during March includes the following completed operations: (1) shipment to LASL experimenters of $2.28 \mathrm{~kg}(5.02$ 1b) of cold-rolled sheets for both impact capsule [1.39 $\mathrm{kg}(3.06 \mathrm{1b})]$ and compatibility $[0.89 \mathrm{~kg}(1.96 \mathrm{lb})]$ test matrices; (2) delivery to ORNL experimenters of $1.38 \mathrm{~kg}(3.04 \mathrm{lb})$ of cold-rolled sheets for both mechanical property $[0.92 \mathrm{~kg}(2.03 \mathrm{lb})]$ and welding $[0.46 \mathrm{~kg}$ (1.01 1b)] characterizations; (3) fabrication of a second consumable vacuum-arc-melted scale-up ingot, which has been machined into a right circular cylinder of 73.7-mm(2.90-in.-) diam $\times 111.8-\mathrm{mm}-(4.40-\mathrm{in} .-)$ height of $8.35-\mathrm{kg}-(18.4-1 \mathrm{~b}-)$ weight; and (4) issuance of a request for a commercial company to cast one argon-induction-melted slab [19-mm- (0.75-in.-) thick $\times 101.6-m m-(4.0-i n .-)$ wide $\times 152.4-\mathrm{mm}-(6.0$-in.-) long] of about $5.61 \mathrm{~kg}(12.37 \mathrm{lb})$ from ORNL's prealloyed material. From the above ingot and slab, we plan to provide additional sheets of Pt-3008 for both LASL and ORNL studies.

Our fabrication of the $\mathrm{Pt}-3008$ sheets that were provided to LASL and ORNL experimenters during March entails many distinct operations and parameters. Their history includes preparation of our first consumable vacuumarc-melted scale-up ingot $[5.9 \mathrm{~kg}(13.0 \mathrm{lb})]$; extrusion of the ingot at 
$1300^{\circ} \mathrm{C}\left(2372^{\circ} \mathrm{F}\right)$ with a reduction of area of about $80 \%$ [usable material: $5.0 \mathrm{~kg}(11.01 \mathrm{~b})]$; cross rolling of saw-cut sections of the extruded bar at $1200^{\circ} \mathrm{C}\left(2192^{\circ} \mathrm{F}\right)$ to a reduction in thickness of about $60 \%$ followed by recrystallizing at the rolling temperature; long rolling of the crossrolled and annealed sections at $1000^{\circ} \mathrm{C}\left(1832^{\circ} \mathrm{F}\right)$ to a reduction in thickness of about either $83.5 \%$ or $76.7 \%$ to obtain 0.89 - or $1.27-\mathrm{mm}$ - (35- or 50 -mil) thick hot-rolled plates, respectively; shearing in half the hot-rolled plates to facilitate edge trimming, stress relieving of the trimmed plates for $1 \mathrm{hr}$ at $900^{\circ} \mathrm{C}\left(1652^{\circ} \mathrm{F}\right)$ and less than $1.3 \times 10^{-2} \mathrm{~Pa}\left(<1 \times 10^{-4}\right.$ torr $)$; and rolling at room temperature to a reduction in thickness of about either 50 or $40 \%$ to obtain, respectively, cold-rolled sheets of 0.51 - or $0.64-\mathrm{mm}$ (20- or 25-mil) thickness. Losses of material from sawing and/or trimming of the ingot, extruded bar, hot-rolled plate, and cold-rolled sheets and from allocations for chemical analyses, rolling studies, and heat treatment studies account for $33 \%$ of the starting ingot weight.

U1trasonic inspection of the cold-rolled sheets from our first scaleup ingot revealed two types of defects that slightly reduced the yield of "acceptable" material from 67 to $62 \%$. After the stress-relieving treatment and before cold rolling, the particular sheet that came from the near vicinity of both the bottom of the ingot and the nose of the extrusion exhibited a blister of surface dimensions of $20 \mathrm{-mm}-(3 / 4-\mathrm{in}$. -) width $x$ 50-mm-(2-in.-) length. After cold rolling to a reduction in thickness of about $40 \%$, the blistering region lacked visual distinguishable features on both top and bottom surfaces of the sheet, but was readily defined with ultrasonic through transmission techniques. This defect could conceivably arise from internal surface-connected porosity ("cold shuts") in the ingot that entraps air during extrusion. Subsequent ingots will be machined to expose defects in the near vicinity of their outer surfaces, which can then be repaired by electron-beam-welding techniques before extrusion.

The second type of defect was associated with the shearing operation of the hot-rolled plates to facilitate edge trimming. After cold rolling, ultrasonic inspection showed indications of delaminations of various lengthwise extents in the vicinity of the end of each sheet that was sheared in half at a thickness of about $1.27 \mathrm{~mm}$ ( $50 \mathrm{mils})$. Hot-rolled plates that were divided similarly into two pieces at a thickness of about $0.89 \mathrm{~mm}$ (35 mils) were free of this type of defect. 
Based on ORNL's tentative compositional 1imits of $28.0-30.0$ wt $\% \mathrm{Rh}$ and 7.8-8.2 wt $\% \mathrm{~W}$ for $\mathrm{Pt}-3008$, the rolled sheets from the extremes of the extruded bar contain $2-4 \%$ excess $\mathrm{Rh}$ and a slight deficiency (0.1 wt $\%$ ) of tungsten, while a deficit of $0.7 \mathrm{wt} \%$ in both $\mathrm{Rh}$ and $\mathrm{W}$ alloying elements exists in the central areas of the extrusion. Table 1.3 presents the results of chemical analyses from specimens of cold-rolled sheets and permits comparison of these values to those obtained previously in corresponding regions of the nose, center, and tail of the extruded bar. Impurities that were detected at concentrations of less than $10 \mathrm{ppm}$ and not included in Table 1.3 are $\mathrm{B}, \mathrm{Ca}, \mathrm{Co}, \mathrm{Au}$, In, $\mathrm{Mn}, \mathrm{Os}, \mathrm{P}, \mathrm{Ru}, \mathrm{Ta}, \mathrm{Th}, \mathrm{U}$, and $\mathrm{V}$. In

Table 1.3. Results of Chemical Analysis of Specimens from Extruded Bar and Cold-Rolled Sheets of Pt-3008 A11oy

\begin{tabular}{|c|c|c|c|c|c|c|}
\hline \multirow{3}{*}{ Element } & \multicolumn{6}{|c|}{ Detected Concentration } \\
\hline & \multicolumn{3}{|c|}{ Extruded Bar } & \multicolumn{3}{|c|}{ Cold-Rolled Sheets } \\
\hline & Nose & Center & Tail & Nose & Center & Tail \\
\hline \multicolumn{7}{|c|}{ Alloying Elements, wt $\%$} \\
\hline $\begin{array}{l}\text { Rhodium } \\
\text { Tungsten } \\
\text { Platinum }\end{array}$ & $\begin{array}{r}30.40 \\
7.84 \\
61.90\end{array}$ & $\begin{array}{r}30.70 \\
7.79 \\
61.50\end{array}$ & $\begin{array}{r}30.30 \\
7.77 \\
62.00\end{array}$ & $\begin{array}{r}33.76 \\
7.66 \\
58.58\end{array}$ & $\begin{array}{r}27.29 \\
7.13 \\
65.58\end{array}$ & $\begin{array}{r}32.45 \\
7.77 \\
59.78\end{array}$ \\
\hline \multicolumn{7}{|c|}{ Trace Elements, ${ }^{c}$ ppm } \\
\hline Aluminum & 1 & 1 & 1 & 5 & 3 & 30 \\
\hline Carbon & 21 & 17 & 35 & 68 & 56 & 53 \\
\hline Chromium & 3 & 10 & 30 & 25 & 50 & 70 \\
\hline Copper & 50 & 50 & 50 & 100 & 40 & 500 \\
\hline Iridium & 25 & 20 & 15 & 10 & 15 & 12 \\
\hline Iron & 50 & 50 & 100 & 70 & 70 & 100 \\
\hline Molybdenum & 20 & 10 & 100 & 50 & 30 & 50 \\
\hline Nickel & & & & 30 & 20 & 40 \\
\hline Oxygen & 9 & 8 & 10 & 18 & 24 & 29 \\
\hline Palladium & & & & 10 & 10 & 15 \\
\hline Silicon & 10 & 10 & 3 & 20 & 30 & 100 \\
\hline Silver & & & & 10 & 10 & 15 \\
\hline Sulfur & 5 & 1 & 5 & 15 & 7 & 100 \\
\hline Titanium & & & & 3 & 40 & 2 \\
\hline Zirconium & 10 & 15 & 5 & $\leq 25$ & $\leq 15$ & $\leq 10$ \\
\hline
\end{tabular}


general, the levels of trace elements in the rolled sheets from the three sampling locations are higher than the values for the extruded bar by up to one order of magnitude. These analyses indicate that the rolled sheets are of sufficient uniformity and purity and will serve adequately for forming and compatibility studies and for evaluation of properties.

Figure 1.8 shows general changes in microstructure and microhardness that occur during the fabrication of Pt-3008 sheets from a consumable electrode arc-melted ingot. As shown in Fig. 1.8, the cast alloy exhibits fairly equiaxed grains of average hardness of $200 \mathrm{DPH}$. This structure breaks up during extrusion to produce alternating layers of partially recrystallized and wrought appearing grains of average hardness of 285 DPH. During subsequent hot-rolling and annealing operations, the materials undergo complete recrystallization and grain growth. At this stage of fabrication, its appearance is again equiaxed grains of considerably smaller size than those of the cast ingot but of similar hardness (210 vs $200 \mathrm{DPH})$. Our warm-rolling and stress-relieving steps yield the desired fibrous structure and produce a hardness of $340 \mathrm{DPH}$. The final fabricating step, a $50 \%$ reduction in thickness at room temperature followed by a stress-relieving treatment, further raises the hardness of the sheet to $425 \mathrm{DPH}$.

The hardness of cold-rolled sheets of Pt-3008 increases with increasing amounts of reduction in thickness at room temperature. And, the rate of increase is greater for recrystallized than for fibrous-appearing material. Figure 1.9 shows the effect of various reductions on the hardness of specimens having different pre- or post-cold-rolling heat treatments. Before cold rolling, the material was fabricated as outlined in Fig. 1.8 and then heated $1 \mathrm{hr}$ at either 900,1000 , or $1200^{\circ} \mathrm{C}\left(1652,1832\right.$, or $\left.2192^{\circ} \mathrm{F}\right)$ and less than $1.3 \times 10^{-2} \mathrm{~Pa}\left(<1 \times 10^{-4}\right.$ torr $)$. If heated after cold rolling, similar time and pressure parameters were used for the final $870^{\circ} \mathrm{C}\left(1598^{\circ} \mathrm{F}\right)$ heat treatment. As shown in Fig. 1.9, the estimate of standard deviation of an individual hardness measurement is $\pm 9 \mathrm{DPH}$, and each plotted point represents the arithmetic mean of five replicated determinations from one specimen.

The microstructures of some of the hardness specimens for Fig. 1.9 that are in the warm-rolled and heat-treated, and cold-rolled and stress-relieved conditions are shown in Fig. 1.10. The warm-rolled materials that were heat treated at either 900 or $1000^{\circ} \mathrm{C}\left(1652\right.$ or $1832^{\circ} \mathrm{F}$ ) 

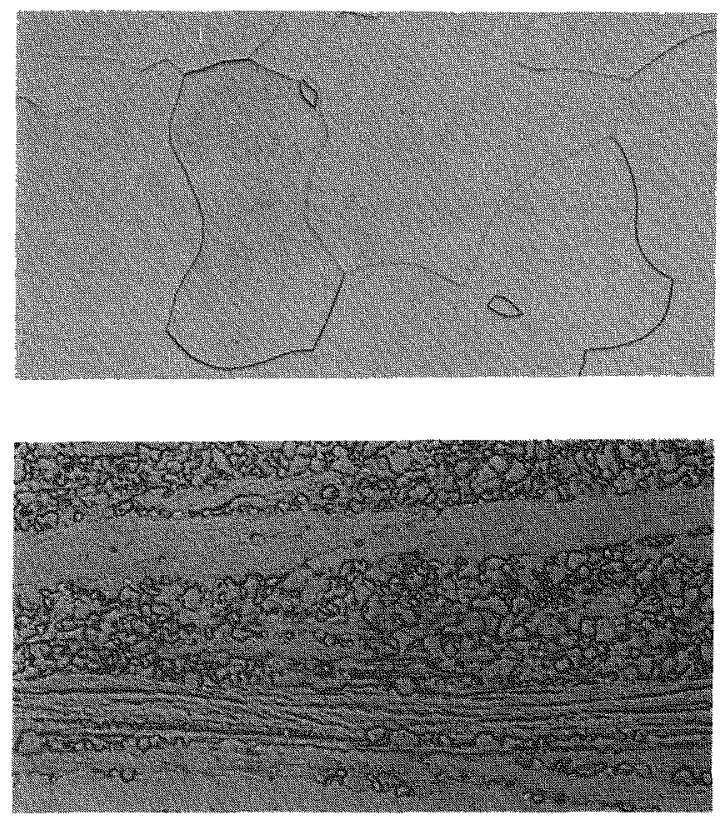

Consumable electrode arc-melted $200 \mathrm{DPH}$

\author{
Extruded \\ $\left(1300^{\circ} \mathrm{C}, 80 \%\right.$ reduction) \\ $285 \mathrm{DPH}$
}

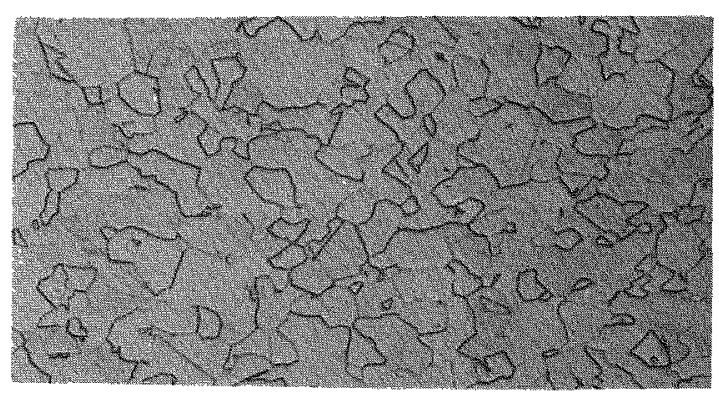

Hot-rolled $\left(1200^{\circ} \mathrm{C}, 60 \%\right.$ reduction) and annealed $\left(1200^{\circ} \mathrm{C}\right.$ for $\left.1 \mathrm{hr}\right)$ $210 \mathrm{DPH}$

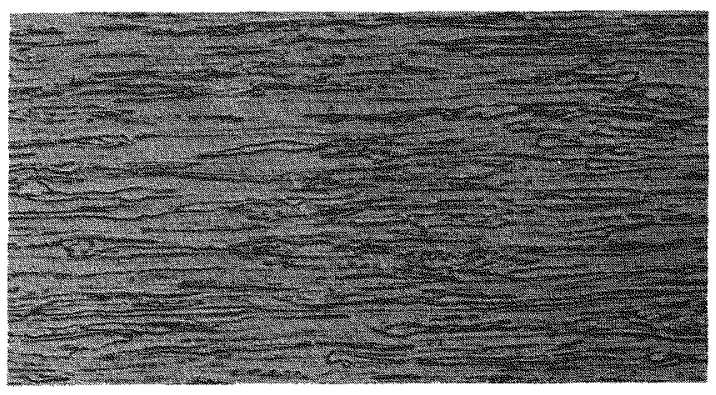
Warm-rolled $\left(1000^{\circ} \mathrm{C}, 80 \%\right.$ reduction) and stress relieved $\left(900^{\circ} \mathrm{C}\right.$ for $\left.\mathrm{I} \mathrm{hr}\right)$ $340 \mathrm{DPH}$

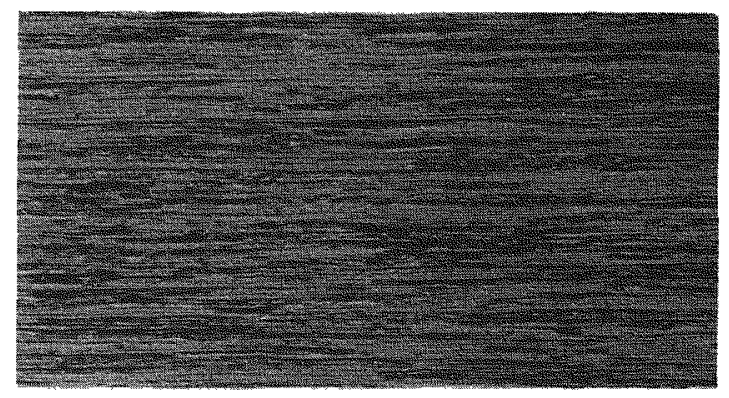

Cold-rolled $\left(20^{\circ} \mathrm{C}, 50 \%\right.$ reduction $)$ and stress relieved $\left(870^{\circ} \mathrm{C}\right.$ for $\left.1 \mathrm{hr}\right)$ $425 \mathrm{DPH}$

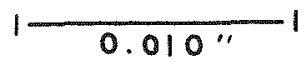

Fig. 1.8. Microstructure of Pt-3008 Sheet at Various Stages of Fabrication. Etched electrolytically. 100x. 


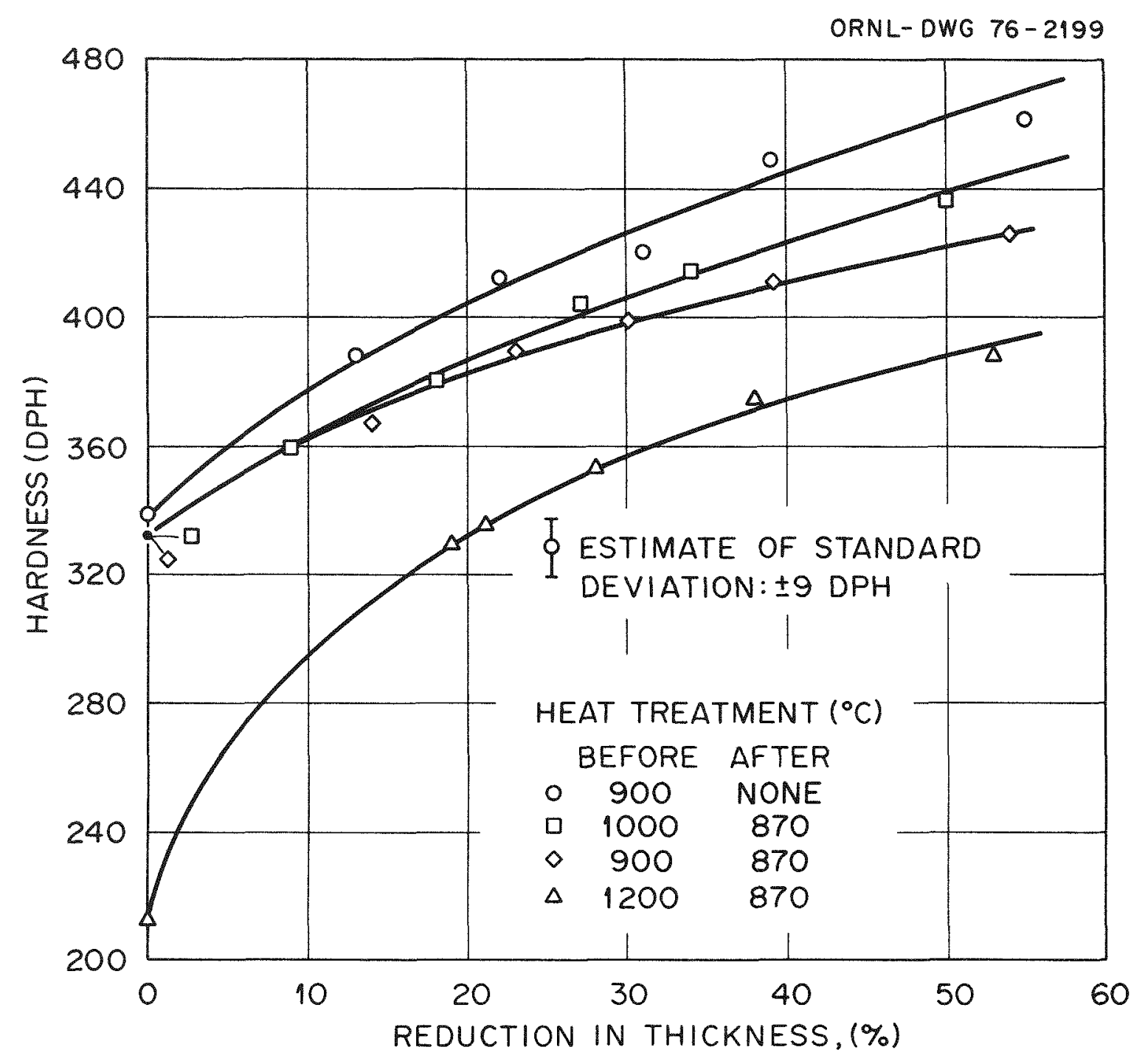

Fig. 1.9. Effect of Rolling at Room Temperature on Diamond-Pyramid Hardness Number of Pt-3008 Sheets of Differing Heat Treatments. 


\section{WARM-ROLLING \\ TEMPERATURE}

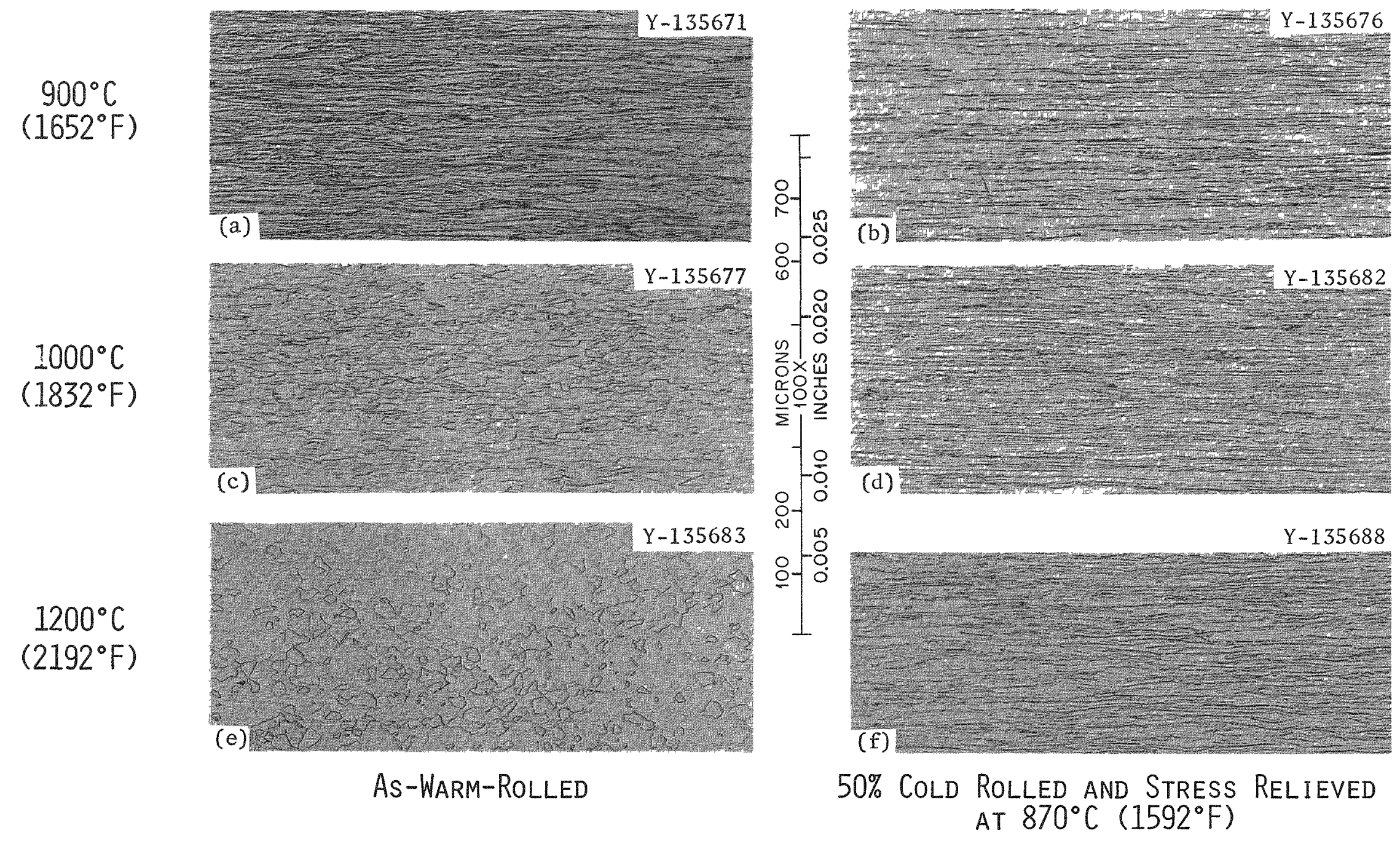

Fig. 1.10. Polished and Etched Speciemns of Pt-3008 Sheets Fabricated from Extruded Bar. 
before cold rolling retained their fibrous structures throughout the various reductions at room temperature and subsequent stress relief at $870^{\circ} \mathrm{C}$ $\left(1598^{\circ} \mathrm{F}\right)$. Their hardness values were, respectively, $461 \pm 4$ and $459 \pm 11$ DPH after cold rolling a total of $50 \%$ and $426 \pm 11$ and $436 \pm 12$ DPH after stress relieving.

The $1200^{\circ} \mathrm{F}\left(2192^{\circ} \mathrm{F}\right)$ treatment before cold rolling of these hardness specimens fully recrystallizes the warm-rolled structure, as shown in Fig. 1.10. During cold rolling, the fairly equiaxed grains distorted and elongated in the direction of rolling, but still exhibited granularity after a total reduction of $50 \%$ in thickness. For this amount of cold rolling, the stress-relieving treatment lowered its hardness from $431 \pm 17$ to $388 \pm 13 \mathrm{DPH}$.

\subsubsection{Welding of Pt-3008 Alloy - G. M. Goodwin}

Preparation of gas tungsten-arc weld specimens from sheet LCPT-10 has been hindered by cracking which frequently occurs during the specimen punching operation. Results of tests on the specimens which have been successfully punched are given in Table 1.4 , to be compared with previously reported data. ${ }^{4}$ Also included are base metal data for reference purposes. As noted previously, reannealing $1 \mathrm{hr}$ at $1200^{\circ} \mathrm{C}$ causes an improvement in room-temperature ductility to $10 \%$ tota 1 elongation, and an increase in strength (specimen 10-106 vs specimen 10-107).

The longitudinal gas tungsten-arc specimen (10-17) shows strength and ductility essentially equivalent to base metal. Welds made by either process in reannealed sheet (10-18 and 10-19) show reduced strength and ductility when compared to reannealed base metal (10-107), with the gas tungsten-arc weld showing lower ultimate strength than the electron-beam weld. Fracture occurred in the gas tungsten-arc weld metal and outside the electron-beam weld metal.

Postweld heat treatment of $1 \mathrm{hr}$ at $1200^{\circ} \mathrm{C}$ improves both the strength and ductility of welds made by either process. Again, though, the gas tungsten-arc weld has lower ultimate strength and only a marginal improvement in ductility, and fracture occurs in the weld metal.

Three additional specimens are being prepared by machining to assure that the data obtained from punched specimens are not seriously influenced by the punching operation. 
Table 1.4. Tensile Properties of Pt-3008 Electron-Beam Weldments ${ }^{\mathrm{a}}$

\begin{tabular}{|c|c|c|c|c|c|c|}
\hline \multirow{2}{*}{$\begin{array}{c}\text { Specimen } \\
\text { Designation }\end{array}$} & \multirow{2}{*}{$\begin{array}{c}\text { Test } \\
\text { Temperature } \\
\left({ }^{\circ} \mathrm{C}\right)\end{array}$} & \multirow{2}{*}{ Type } & \multicolumn{2}{|c|}{ Strength, MPa(ksi) } & \multirow{2}{*}{$\begin{array}{c}\text { Total } \\
\text { Elongation } \\
\left(\begin{array}{c}\% \\
0\end{array}\right)\end{array}$} & \multirow{2}{*}{$\begin{array}{l}\text { Fracture } \\
\text { Location }\end{array}$} \\
\hline & & & $\begin{array}{l}0.2 \% \\
\text { Yield }\end{array}$ & U1timate & & \\
\hline $10-17$ & 20 & L-GTA & $413.7(60)$ & $537.8(78)$ & 2.0 & - \\
\hline $10-18$ & 20 & $\mathrm{R}-\mathrm{T}-\mathrm{GTA}$ & $275.8(40)$ & $399.9(58)$ & 2.0 & weld \\
\hline $10-19$ & 20 & $R-T-E B$ & $275.8(40)$ & $482.6(70)$ & 2.0 & base metal \\
\hline $10-20$ & 20 & $\mathrm{R}-\mathrm{T}-\mathrm{GTA}-\mathrm{P}$ & $344.8(50)$ & $441.3(64)$ & 2.5 & weld \\
\hline $10-21$ & 20 & $R-T-E B-P$ & $344.8(50)$ & $496.4(72)$ & 5.0 & base metal \\
\hline $10-106$ & 20 & B & $473.2(68.6)$ & $500.2(72.5)$ & 2.0 & - \\
\hline $10-107$ & 20 & $\mathrm{BR}$ & $511.7(74.2)$ & $632.9(91.8)$ & 10.0 & - \\
\hline
\end{tabular}

${ }^{a}$ Full-penetration welds in $0.56-\mathrm{mm}(0.022$-in.) sheet, previously annealed $1 \mathrm{hr}$ at $1000^{\circ} \mathrm{C}$.

$\mathrm{b}_{\mathrm{B}}=$ base metal; $\mathrm{L}=$ weld longitudinal to specimen axis; $\mathrm{T}=$ weld transverse to specimen axis at center of gage length; $\mathrm{R}=$ base metal reannealed $1 \mathrm{hr}$ at $1200^{\circ} \mathrm{C}$ prior to welding; $G T A=$ gas tungsten-arc weld; $E B=$ electron-beam weld; and $\mathrm{P}=$ postweld annealed 1 hr at $1200^{\circ} \mathrm{C}$. 
Two sheets (2B and 5A) from the scale-up heat $E 1$ have been received, and electron-beam weld specimens are being prepared.

\subsection{Ruthenium and Rhodium Alloys}

\section{H. Inouye}

\subsubsection{Ruthenium Fabrication and Characterization}

The fabricability and properties of ruthenium- and rhodium-base alloys are being characterized in an attempt to develop suitable cladding materials for isotopic fuels with lower density and/or lower cost than iridiumor platinum-base alloys. As previously reported, the fabrication of cast ingots of ruthenium alloys using procedures suitable for iridium- or platinum-base alloy sheet resulted in severe ingot cracking. ${ }^{5}$

In order to establish a suitable rolling temperature, three electronbeam-melted buttons of ruthenium, weighing about $75 \mathrm{~g}$ each, were canned in molybdenum and reduced about 50\% in thickness by rolling at 1300, 1400, and $1500^{\circ} \mathrm{C}$, then further rolled at $1000^{\circ} \mathrm{C}$ to $2.032-\mathrm{mm}-(0.080-$ in. -$)$ thick sheet for a total reduction of about $80 \%$. Although each sheet was free of visible cracks, numerous pinholes were present whose number and size decreased with rolling temperature.

A powder compact of ruthenium and a $\mathrm{Ru}-0.5 \% \mathrm{La}$ alloy, sintered to about $90 \%$ of theoretical density, was also rolled to $1400^{\circ} \mathrm{C}$ in a molybdenum can from a thickness of $5.08 \mathrm{~mm}(0.20 \mathrm{in.})$ to about $2.54 \mathrm{~mm}(0.10 \mathrm{in.})$, then further rolled to $1.27-\mathrm{mm}-(0.05-\mathrm{in} .-)$ thick sheet at $1000^{\circ} \mathrm{C}$. Both sheets also contained numerous pinholes. These rolling experiments indicate that the pinholes, being common to both the cast ingots and the sintered compacts, are caused by the molybdenum can and not attributable to the grain size or grain morphology of the ruthenium alloys.

Phase relationships in the ruthenium-rhodium and ruthenium-platinum alloy systems are being studied metallographically and by $x$-ray analyses. The solubility of rhodium in ruthenium and ruthenium in rhodium has been verified to be at least 20 at. $\%$ as reported. ${ }^{6}$ Four ruthenium-platinum alloys containing up to 20 at. $\%$ pt have been cast, sectioned, and heat treated for phase studies. 


\subsection{References}

1. A. C. Schaffhauser, Isotopic Power Materials Development Quart. Progr. Rep. Dec. 31, 1975, ORNL/TM-5285, pp. 1-3.

2. F. A. Shunk, Constitution of Binary AZZoys, Second Supplement, McGrawHill Book Company, New York, New York (1969), p. 466.

3. A. C. Schaffhauser, Isotopic Power Materials Development Quart. Progr. Rep. Dec. 31, 1975, ORNL/TM-5285.

4. Ibid, pp. 15-26.

5. Ibid, pp. 29-33.

6. R. W. Douglass, C. A. Krier, and R. I. Jaffee, High-Temperature Properties and Alzoying Behavior of Refractory Pt-Group Metals, (BMI) NP-10939 (August 1961). 
Blank 
2. PHYSICAL AND MECHANICAL METALLURGY OF HEAT-SOURCE CONTAINMENT MATERIALS*

\subsection{Introduction}

The high reliability in long-term unattended operation, high operating temperatures, and potentially severe accident conditions of isotope-fueled energy conversion systems require that materials for critical components be exclusively tested and that the limitations on their use be defined. The objective of this progxam is to evaluate and determine the suitability and limitations of such materials. To accomplish this objective, we have concentrated our efforts on the evaluation of materials under the most severe otential accident conditions (e.g., high velocity reentry and impact of an isotope heat source from space after long-term operation). The potential degradation of material properties from environmental and impurity effects is being evaluated along with studies on the mechanisms controlling the properties of materials of interest. In addition, special projects and con-sulting on materials problems for isotope-fueled energy conversion systems are performed as requested by ERDA.

\subsection{Characterization of Impact Properties}

\subsubsection{Impact Properties of Iridium Alloys - C. T. Liu}

2.2.1.1 DOP-4 Dopant Effect. - Tensile specimens of DOP-13, -15, and -16 alloys were heat treated $19 \mathrm{hr}$ at $1500^{\circ} \mathrm{C}$ and then impact tested at $1350^{\circ} \mathrm{C}$ at a velocity of $85 \mathrm{~m} / \mathrm{sec}(280 \mathrm{fps})$ to determine the effects of DOP-4 series of dopants on impact properties. The results are presented in Table 2.1 and are compared with DOP-4 alloy and undoped WG. The alloys Dop-13, -16, and -4 , all doped with $40 \mathrm{ppm} \mathrm{Al} \mathrm{(in} \mathrm{addition} \mathrm{to} 30 \mathrm{ppm} \mathrm{Th}$ ), had 26.6-27.2\% elongation, 56-64\% reduction of area, and their fracture mode was transgranular fracture and ductile rupture. In comparison, the DOP-15, not doped with aluminum, has only $15.1 \%$ elongation and $39 \%$ reduction of area, and its fracture mode is grain-boundary separation and transgranular fracture. These results strongly indicate that aluminum, in addition to thorium, has very significant effects on improving impact properties of $\operatorname{Ir}-0.3 \% \mathrm{~W}$ alloys.

*Progress on work performed under Activity No. KJ 300102 3, 189a No. 00002 . 
Table 2.1. Effect of DOP-4 Series of Dopants on Tensile Impact Properties of $\mathrm{Ir}-0.3 \% \mathrm{~W}$ Alloys Heat Treated $19 \mathrm{hr}$ at $1500^{\circ} \mathrm{C}$ and Tested at $85 \mathrm{~m} / \mathrm{sec}(280 \mathrm{fps})$ at $1350^{\circ} \mathrm{C}$

\begin{tabular}{llcccc}
\hline Specimen & $\begin{array}{c}\text { Nominal Dopant } \\
\text { Concentration } \\
(\mathrm{ppm})\end{array}$ & $\begin{array}{c}\text { Grain } \\
\text { Size }\end{array}$ & $\begin{array}{c}\text { Elongation } \\
(\%)\end{array}$ & $\begin{array}{c}\text { Reduction } \\
\text { of Area } \\
(\%)\end{array}$ & Fracture Mode \\
\hline WG-202 & None & 5.8 & 10.7 & 24 & Mainly GBS \\
DOP-15 & $80 \mathrm{Fe}, 30 \mathrm{Th}$ & 8.1 & 15.1 & 39 & TF and GBS \\
DOP-13 & $40 \mathrm{~A} 1,30 \mathrm{Th}$ & 12.2 & 27.2 & 64 & TF and DR \\
DOP-16 & $40 \mathrm{~A} 1,80 \mathrm{Fe}, 30 \mathrm{Th}$ & 10.3 & 26.6 & 56 & TF and DR \\
DOP-4 & $40 \mathrm{~A} 1,80 \mathrm{Fe}, 30 \mathrm{Th}$, & 9.9 & 26.8 & 60 & TF and DR \\
& $16 \mathrm{Ni}, 75 \mathrm{Rh}$ & & & & \\
\hline
\end{tabular}

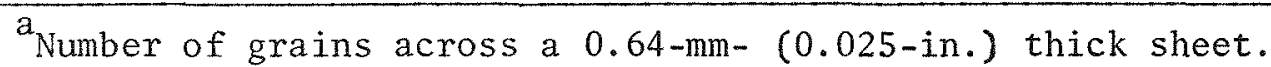

${ }_{\mathrm{GBS}}^{\mathrm{b}}=$ grain-boundary separation; $\mathrm{TF}=$ transgranular fracture; $\mathrm{Ma}=$ major fraction; $M i=$ minor fraction; and $D R=$ ductile rupture.

2.2.1.2 Thorium Concentration Effect. - The tensile impact properties of $\operatorname{Ir}-0.3 \% \mathrm{~W}$ alloys doped to $1000 \mathrm{ppm}$ Th were determined for three heattreatment conditions: $1 \mathrm{hr}$ at $1500^{\circ} \mathrm{C}, 19 \mathrm{hr}$ at $1500^{\circ} \mathrm{C}$, and a complex heat treatment of $1 \mathrm{hr}$ at $1500^{\circ} \mathrm{C}$ plus $1 \mathrm{hr}$ at $1800^{\circ} \mathrm{C}$ plus $1 \mathrm{hr}$ at $1500^{\circ} \mathrm{C}$. All the heat-treated specimens were impacted at a velocity of $85 \mathrm{~m} / \mathrm{sec}$ (280 fps) at $1350^{\circ} \mathrm{C}$; the results are presented in Table 2.2. After a heat treatment of $1 \mathrm{hr}$ at $1500^{\circ} \mathrm{C}$, the impact elongation increases with increasing thorium content in the alloy to $100 \mathrm{ppm}$, but becomes insensitive above this level. The alloys showed ductile rupture with more than $85 \%$ reduction of area after doped with $50 \mathrm{ppm}$ or more. After a heat treatment of $19 \mathrm{hr}$ at $1500^{\circ} \mathrm{C}$, the impact elongation and reduction of area also increased with thorium content and became insensitive to thorium content between 200-1000 ppm. After a severe heat treatment between 1500 and $1800^{\circ} \mathrm{C}, \mathrm{DOP}-14$ and WTh-2 had 25.2-25.4\% elongation and 71-73\% reduction of area and fractured by ductile rupture and transgranular fracture, which are distinctly better than the alloys doped with lower amounts of thorium (see Table 2.2). Thus, the DOP-14 and WTh-2 are most resistant to degradation due to severe heat treatment. The impact data (in Table 2.2), in connection with microstructure analysis and fracture behavior in section 1.2 .1 , suggests that the $\mathrm{Ir}-0.3 \% \mathrm{~W}$ doped with thorium at a level of 200-500 ppm may have the best impact properties. 
Tab1e 2.2. Effects of Thorium Content and Heat Treatment on Tensile Impact Properties of Ir-0.3\% W Sheet Specimens Tested at $85 \mathrm{~m} / \mathrm{sec}\left(280 \mathrm{fps}\right.$ ) and $1350^{\circ} \mathrm{C}$

\begin{tabular}{lrrrrl}
\hline $\begin{array}{c}\text { Alloy } \\
\text { Number }\end{array}$ & $\begin{array}{c}\text { Thorium } \\
\text { Content } \\
\text { (ppm) }\end{array}$ & $\begin{array}{c}\text { Grain } \\
\text { Size }\end{array}$ & $\begin{array}{c}\text { Elongation } \\
\left(\frac{0}{\%}\right)\end{array}$ & $\begin{array}{c}\text { Reduction } \\
\text { of Area } \\
(\%)\end{array}$ & Fracture Mode \\
\hline WG-202 & 0 & 10.7 & 12.6 & 28 & Mainly GBS \\
WTh-1 & 50 & 20.9 & 25.5 & 89 & DR \\
DOP-22 & 100 & 19.3 & 38.2 & 87 & DR \\
DOP-14 & 200 & 25.3 & 37.9 & 92 & DR \\
WTh-2 & 1000 & 27.3 & 39.4 & 87 & DR \\
& & Annealed 1 hr at $1500^{\circ} \mathrm{C}$ & \\
WG-202 & 0 & 5.8 & 10.9 & 23 & Mainly GBS \\
WG-202 & 0 & 5.8 & 10.5 & 24 & Main1y GBS \\
DOP-22 & 100 & 10.8 & 23.8 & 50 & TF \\
DOP-14 & 200 & 15.0 & 28.9 & 84 & DR \\
DOP-14 & 200 & 15.0 & 29.1 & 90 & DR \\
WTh-2 & 1000 & 21.8 & $c$ & 79 & DR \\
WTh-2 & 1000 & 21.8 & 29.0 & 87 & DR
\end{tabular}

Annealed $1 \mathrm{hr}$ at $1500^{\circ} \mathrm{C}+1 \mathrm{hr}$ at $1800^{\circ} \mathrm{C}+1 \mathrm{hr}$ at $1500^{\circ} \mathrm{C}$

\begin{tabular}{|c|c|c|c|c|c|}
\hline WG- 202 & 0 & 2.4 & 2.2 & 7 & Completely \\
\hline WG-202 & 0 & 2.4 & 4.6 & 5 & Compl etely \\
\hline DOP -22 & 100 & 6.5 & 14.1 & 27 & Mainly GBS \\
\hline DOP - 14 & 200 & 12.0 & 25.2 & 71 & DR and TF \\
\hline WTh -2 & 1000 & 14.9 & 25.4 & 73 & $\mathrm{DR}$ and $\mathrm{TF}$ \\
\hline
\end{tabular}

Figure 2.1 shows the plot of impact elongation and fracture behavior as a function of the number of grains across the $0.64-\mathrm{mm}-(0.025-\mathrm{in} .-)$ thick sheet for undoped WG, DOP-4, and DOP-14. For the same grain size, the impact properties of DOP-14 are no better than those of DOP-4. Thus, we believe that the superior impact properties of DOP-14 are due to the precipitation of significant amount of second-phase (probably $\operatorname{ThIr}_{5}$ ) particles which retard grain growth during high-temperature heat treatments. 


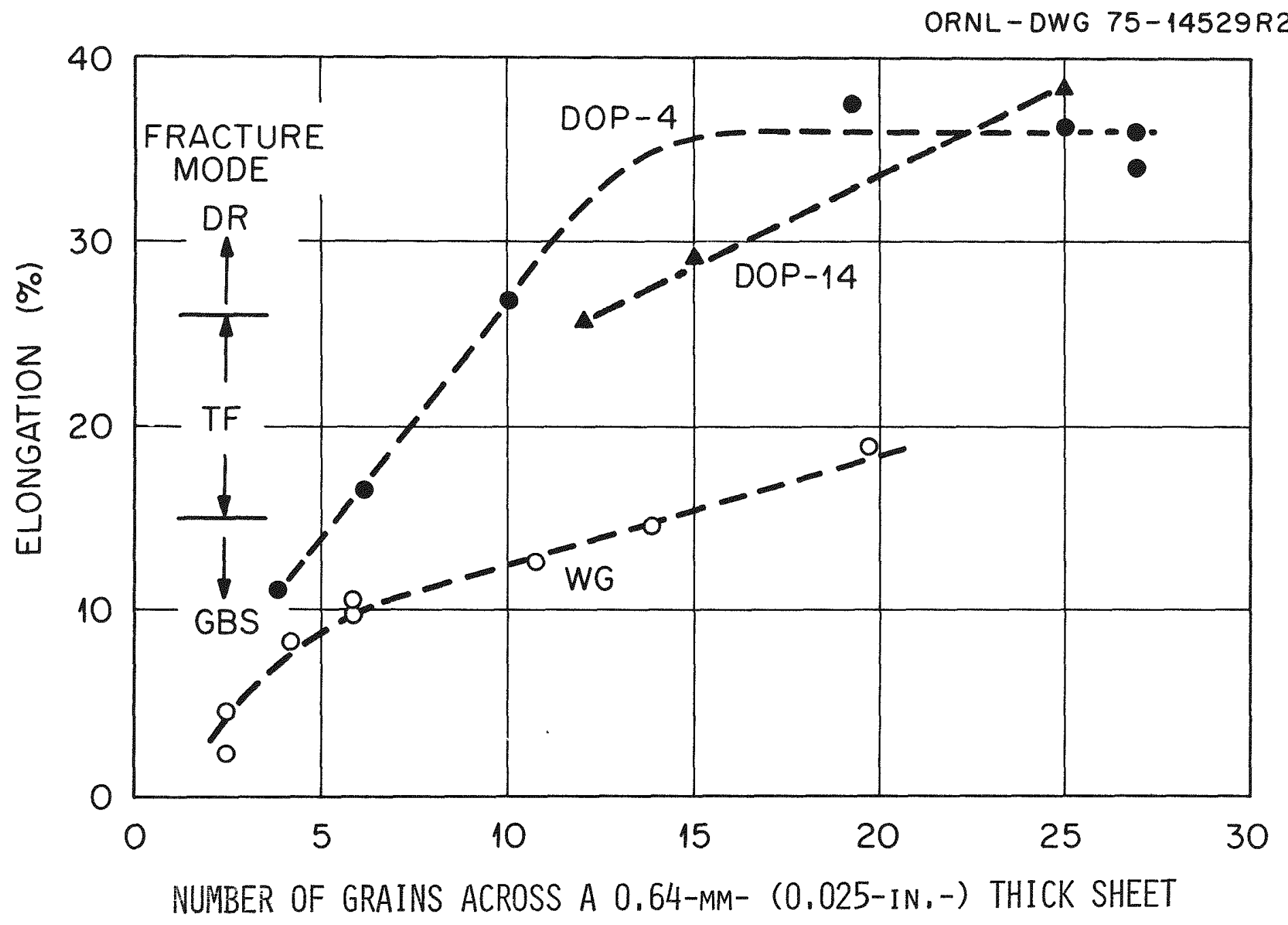

Fig. 2.1. Plot of Impact Elongation as a Function of Grain Size for Ir-0.3\% W Alloys WG, DOP-4, and DOP-14. 
2.2.1.3 Impact Temperature Effect. - Tensile specimens of Ir $-0.3 \% \mathrm{~W}$ alloys were heat treated $1 \mathrm{hr}$ at $1500^{\circ} \mathrm{C}$, and then impact tested in the temperature range $950-1350^{\circ} \mathrm{C}$ to determine the effects of test temperature on impact properties of WG, DOP-4, -13, and -14. Al1 the specimens were impacted at $85 \mathrm{~m} / \mathrm{sec}(280 \mathrm{fps})$; the results are presented in Table 2.3 and Fig. 2.2 as a function of test temperature. The impact properties of WG and DOP-4 specimens are not sensitive to test temperatures above $1200^{\circ} \mathrm{C}$; below this temperature, the elongation and reduction of area decrease with test temperature for these alloys. At $1050^{\circ} \mathrm{C}$, the DOP-14 specimens had $29.2 \%$ elongation and $69 \%$ reduction of area, which are far superior to WG and DOP-4 at the same impact temperature. Thus, DOP-14 appears to be most resistant to low-temperature impact among these alloys. The WG specimen fractured mainly by grain-boundary separation and DOP-14 mainly by ductile rupture at these temperatures, while DOP-4 specimens changed fracture mode from ductile rupture above $1200^{\circ} \mathrm{C}$ to mixed grain-boundary separation and transgranular fracture at $1050^{\circ} \mathrm{C}$. DOP-13 exhibited mainly grain-boundary separation at $950^{\circ} \mathrm{C}$.

\subsubsection{Effects of Long-Term Heat Treatment on Impact Properties of Ir-0.3\% W Alloys - C. T. Liu and D. E. Harasyn}

To study the effects of long-term heat treatments at the MHW fuel clad temperature on the physical and mechanical properties of $\operatorname{Ir}-0.3 \% \mathrm{~W}$ alloys, WG (undoped) and HD (doped with DOP-4 dopants) specimens were annealed at $1330^{\circ} \mathrm{C}$ for various times and then impacted at $1350^{\circ} \mathrm{C}$ and $85 \mathrm{~m} / \mathrm{sec}(280 \mathrm{fps}$ ). The impact data are presented in Table 2.4 and plotted as a logarithmic function of the annealing time in Fig. 2.3. The impact elongation of both alloys decreases with annealing time, and this decrease is apparently due to grain growth at $1330^{\circ} \mathrm{C}$ (see the grain size data in Table 2.4). According to the plot in Fig. 2.3, WG material had a marginal ductility of $14 \%$ elongation after being annealed for only $30 \mathrm{hr}$ at $1330^{\circ} \mathrm{C}$. We believe Ir-0.3\% $\mathrm{W}$ should have at least $14 \%$ elongation in order to survive the MHW/FSA-type impact. Extrapolation of DOP-4 data in Fig. 2.3 indicates that DOP-4 alloy may remain ductile after 10,000-100,000 hr of annealing at $1330^{\circ} \mathrm{C}$. Thus, DOP-4 is much more resistant to degradation due to longterm heat treatment at $1330^{\circ} \mathrm{C}$. 
Table 2.3. Effect of Test Temperature on Tensile Impact Properties of WG, DOP-4, DOP-13, and DOP-14 Sheet Specimens

Heat Treated $1 \mathrm{hr}$ at $1500^{\circ} \mathrm{C}$ and

Tested at $85 \mathrm{~m} / \mathrm{sec}$ (280 fps)

\begin{tabular}{|c|c|c|c|}
\hline $\begin{array}{l}\text { Test } \\
\text { Temperature } \\
\left({ }^{\circ} \mathrm{C}\right)\end{array}$ & $\begin{array}{c}\text { Elongation } \\
(\%)\end{array}$ & $\begin{array}{c}\text { Reduction } \\
\text { of Area } \\
(\%)\end{array}$ & Fracture Mode ${ }^{a}$ \\
\hline \multicolumn{4}{|c|}{ WG Specimens } \\
\hline 1350 & 12.6 & 28 & Main1y GBS \\
\hline 1250 & 13.5 & 27 & Mainly GBS \\
\hline 1150 & 8.6 & 18 & Mainly GBS \\
\hline 1050 & 5.4 & 13 & Mainly GBS \\
\hline 950 & 4.5 & 12 & Mainly GBS \\
\hline \multicolumn{4}{|c|}{ DOP-4 Specimens ${ }^{\mathrm{C}}$} \\
\hline 1350 & 37.6 & 94 & DR \\
\hline 1250 & 38.2 & 82 & $\mathrm{DR}$ \\
\hline 1150 & 21.5 & 54 & $\mathrm{TF}$ \\
\hline 1050 & 15.2 & 44 & \\
\hline 1050 & 13.6 & 25 & GBS and $\mathrm{TF}$ \\
\hline \multicolumn{4}{|c|}{ DOP-13 Specimen ${ }^{\mathrm{d}}$} \\
\hline 950 & 10.3 & 24 & Mainly GBS \\
\hline \multicolumn{4}{|c|}{ DOP-14 Specimens $^{\mathrm{e}}$} \\
\hline 1350 & 37.9 & 92 & $\mathrm{DR}$ \\
\hline 1050 & 29.2 & 69 & $\mathrm{DR}$ and $\mathrm{TF}$ \\
\hline \multicolumn{4}{|c|}{$\begin{array}{l}{ }_{\mathrm{GBS}}=\text { grain-boundary separation; } \mathrm{TF}=\text { transgranular fracture; and } \\
\text { ductile rupture. } \\
{ }^{\mathrm{b}} \text { Undoped } \mathrm{Ir}-0.3 \% \mathrm{~W} \text {. } \\
\mathrm{c}_{\mathrm{Ir}-0.3 \% \mathrm{~W} \text { doped with } \mathrm{DOP}-4 \text { dopants. }} \\
{ }_{\mathrm{d}} \mathrm{Ir}-0.3 \% \mathrm{~W} \text { doped with } 30 \mathrm{ppm} \mathrm{Th} \text { and } 40 \mathrm{ppm} \mathrm{A1.} \\
\mathrm{e}_{\mathrm{Ir}-0.3 \% \mathrm{~W} \text { doped with } 200 \mathrm{ppm} \mathrm{Th} .}\end{array}$} \\
\hline
\end{tabular}




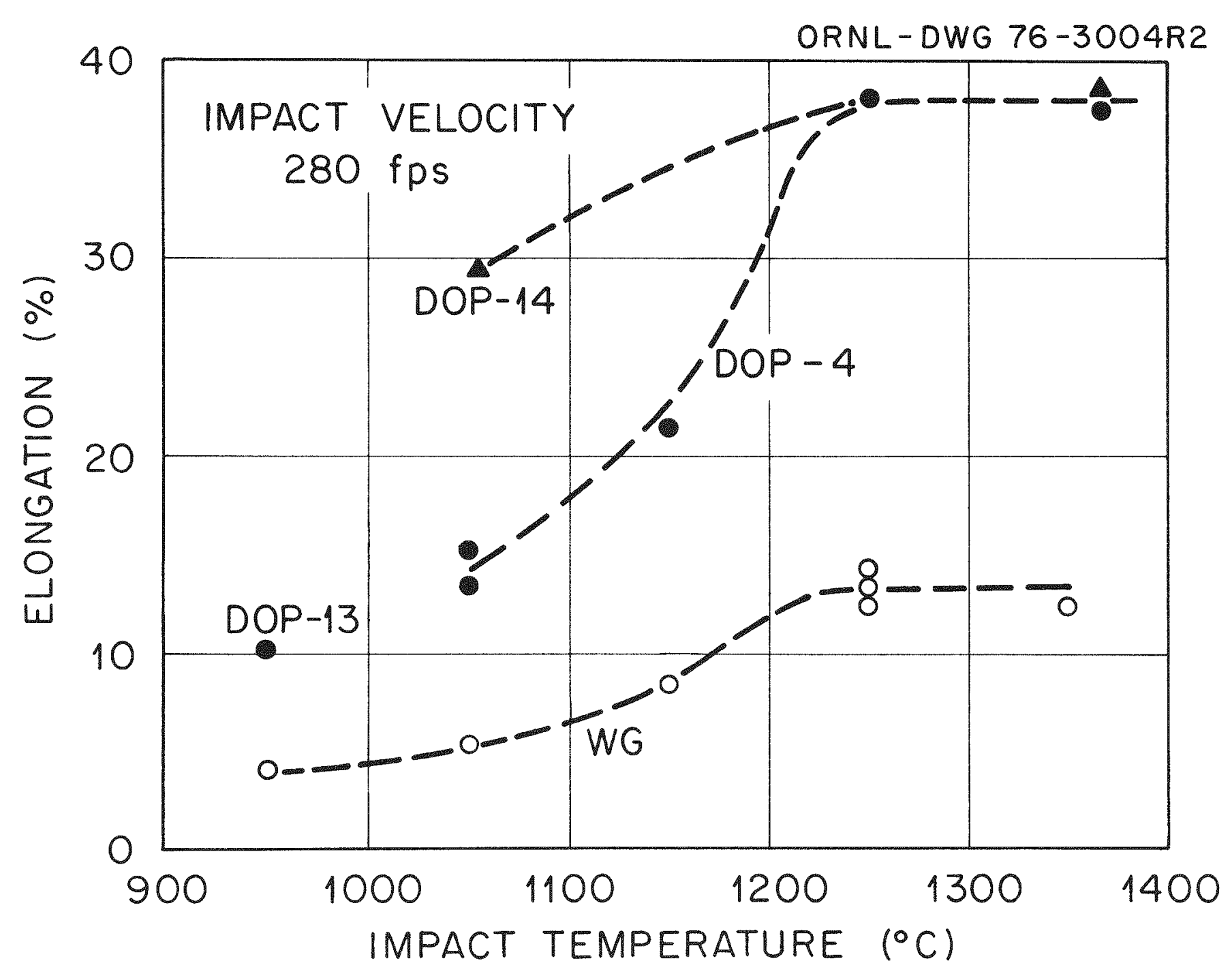

Fig. 2.2. Plot of Impact Elongation as a Function of Impact Temperature for Ir-0.3\% W A11oys WG, DOP-4, DOP-13, and DOP-14. (Al1 specimens heat treated $1 \mathrm{hr}$ at $1500^{\circ} \mathrm{C}$ prior to impact testing.) 
Table 2.4. Effect of Long-Term Anneal at $1330^{\circ} \mathrm{C}$ on the Impact Properties of $W^{\mathrm{a}}$ and $\mathrm{HD}^{\mathrm{b}}$ Specimens Tested at $85 \mathrm{~m} / \mathrm{sec}(280 \mathrm{fps})$ and $1350^{\circ} \mathrm{C}$

\begin{tabular}{|c|c|c|c|c|}
\hline Specimen & $\begin{array}{l}\text { Grain } \\
\text { Size }\end{array}$ & $\begin{array}{c}\text { Impact } \\
\text { Elongation } \\
(\%)\end{array}$ & $\begin{array}{c}\text { Reduction } \\
\text { of Area } \\
(\%)\end{array}$ & Fracture Mode ${ }^{\mathrm{d}}$ \\
\hline \multicolumn{5}{|c|}{$1-\mathrm{hr}$ Annea ${ }^{\mathrm{e}}$} \\
\hline $\begin{array}{l}\text { WG } \\
\text { DOP-4 }\end{array}$ & $\begin{array}{l}19.7 \\
26.9\end{array}$ & $\begin{array}{l}18.7 \\
36.0\end{array}$ & $\begin{array}{l}27 \\
94\end{array}$ & $\begin{array}{l}\text { GBS and TF } \\
\text { DR }\end{array}$ \\
\hline \multicolumn{5}{|c|}{ 200-hx Anneal } \\
\hline $\begin{array}{l}\text { WG } \\
\text { HD }\end{array}$ & - & $\begin{array}{c}13.7 \\
-\end{array}$ & $\begin{array}{r}28 \\
-\end{array}$ & Mainly GBS \\
\hline \multicolumn{5}{|c|}{ 480-hr Annea 1} \\
\hline $\begin{array}{l}\text { WG } \\
\text { HD }\end{array}$ & $\begin{array}{r}8.0 \\
21.5\end{array}$ & $\begin{array}{r}8.4 \\
26.5\end{array}$ & $\begin{array}{l}24 \\
90\end{array}$ & $\begin{array}{l}\text { Mainly GBS } \\
\text { DR }\end{array}$ \\
\hline \multicolumn{5}{|c|}{ 980-hr Anneal } \\
\hline $\begin{array}{l}\text { WG } \\
\text { HD }\end{array}$ & $\begin{array}{r}7.5 \\
16.9\end{array}$ & $\begin{array}{r}8.6 \\
27.2\end{array}$ & $\begin{array}{l}20 \\
88\end{array}$ & $\begin{array}{l}\text { Mainly GBS } \\
\text { DR }\end{array}$ \\
\hline
\end{tabular}

$a_{\text {Undoped Ir }-0.3 \% \mathrm{~W} \text { specimens. }}$

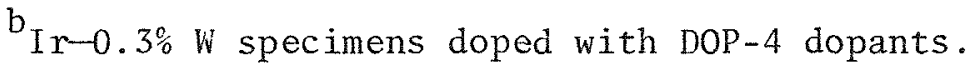

${ }^{c}$ Number of grains across a $0.64-\mathrm{mm}-(0.025-\mathrm{in} .-)$ thick sheet.

$\mathrm{d}_{\mathrm{GBS}}=$ grain-boundary separation; $\mathrm{TF}=$ trans granular fracture; and $\mathrm{DR}=$ ductile rupture.

eAnneal $1 \mathrm{hr}$ at $1300^{\circ} \mathrm{C}$. 


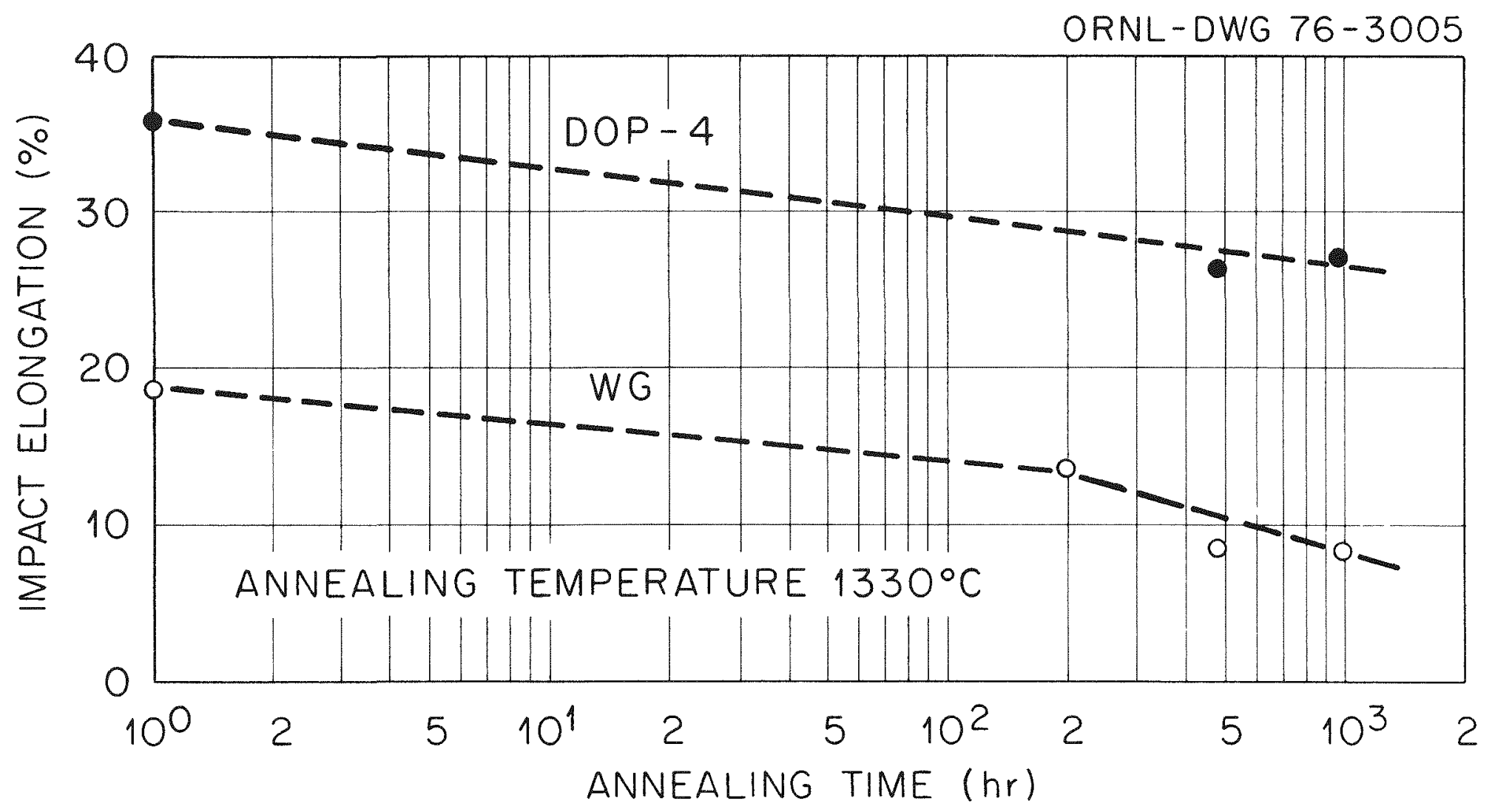

Fig. 2.3. Effect of Long-Term Annealing at $1330^{\circ} \mathrm{C}$ on Impact Elongation of WG and DOP-4 Specimens Impacted at $1350^{\circ} \mathrm{C}$ and $85 \mathrm{~m} / \mathrm{sec}(280 \mathrm{fps})$. 


\subsection{Environmental and Impurity Effects}

\subsubsection{Pt-3008 Air Oxidation - H. Inouye}

Oxidation tests of Pt-3008 tensile specimens in still air, scheduled for 10,000 hr, logged $3861 \mathrm{hr}$ on March 22, 1976. As observed in a prior set of tests, a dark gray oxide film was present on the specimens oxidized at $800^{\circ} \mathrm{C}$, but was not evident on specimens oxidized at 600 or $1000^{\circ} \mathrm{C}$. Weight changes also confirm prior results as follows: (a) weight changes are very small at all test temperatures; (b) at $800^{\circ} \mathrm{C}$, the specimens gain weight but 10 se weight at $1000^{\circ} \mathrm{C}$; (c) weight changes at $600^{\circ} \mathrm{C}$ are too $10 \mathrm{w}$ to determine a trend.

Table 2.5 shows the effects of oxidation on the tensile properties at the oxidation temperature. No significant environmental effects were noted in specimens exposed to $3042 \mathrm{hr}$ at $600^{\circ} \mathrm{C}$; however, the data show a slight

Table 2.5. Tensile Properties of $\mathrm{Pt}-3008$ (Heat Pt-5C) Oxidized in Still Aira

\begin{tabular}{|c|c|c|c|c|c|c|}
\hline \multicolumn{3}{|c|}{ Exposure Conditions } & \multicolumn{2}{|c|}{ Strength, MPa(ksi) } & \multirow{2}{*}{$\begin{array}{c}\text { Elongation } \\
(\%)\end{array}$} & \multirow{2}{*}{$\begin{array}{c}\text { Reduction } \\
\text { of Area } \\
\left(\frac{\%}{0}\right)\end{array}$} \\
\hline $\begin{array}{l}\text { Time } \\
(h r)\end{array}$ & $\begin{array}{c}\text { Temperature } \\
\left({ }^{\circ} \mathrm{C}\right)\end{array}$ & Environment & Ultimate & $\begin{array}{l}0.2 \% \\
\text { Yield }\end{array}$ & & \\
\hline \multicolumn{7}{|c|}{$600^{\circ} \mathrm{C}$} \\
\hline 1 & 1200 & Vac (Annealed) & $594.6(86.3)$ & $198.4(28.8)$ & 34.8 & $\sim 100$ \\
\hline 1000 & 600 & $\operatorname{Vac}$ (Control) & $642.1(93.2)$ & $232.9(34.8)$ & 34.8 & 79.2 \\
\hline 1000 & 600 & Air & $627.0(91.0)$ & $231.5(33.6)$ & 32.0 & 84.9 \\
\hline 3042 & 600 & Air & $635.3(92.2)$ & $248.7(36.1)$ & 28.4 & 79.0 \\
\hline \multicolumn{7}{|c|}{$800^{\circ} \mathrm{C}$} \\
\hline 1 & 1200 & Vac (Annealed) & $540.2(78.4)$ & $182.6(26.5)$ & 28.5 & 77.7 \\
\hline 1000 & 800 & $\operatorname{Vac}$ (Contro1) & $496.8(72.1)$ & $184.0(26.7)$ & 27.0 & 63.8 \\
\hline 1000 & 800 & Air & $347.3(50.4)$ & $190.2(27.6)$ & 18.2 & 21.9 \\
\hline 3042 & 800 & Air & $184.0(26.7)$ & $184.0(26.7)$ & 1.6 & 2.7 \\
\hline \multicolumn{7}{|c|}{$1000^{\circ} \mathrm{C}$} \\
\hline 1 & 1200 & Vac (Annealed) & $311.4(45.2)$ & $170.2(24.7)$ & 13.2 & 11.6 \\
\hline 1000 & 1000 & Vac (Control) & $351.4(51.0)$ & $134.4(19.5)$ & 38.6 & 48.0 \\
\hline 3042 & 1000 & $\operatorname{Vac}$ (Contro1) & $323.1(46.9)$ & $109.6(15.9)$ & 38.0 & 53.1 \\
\hline 1000 & 1000 & Air & $188.1(27.3)$ & $126.1(18.3)$ & 8.8 & 14.0 \\
\hline 3042 & 1000 & Air & $130.2(18.9)$ & $101.3(14.7)$ & 4.2 & 5.0 \\
\hline
\end{tabular}

${ }^{a}$ Specimen gage dimensions: $12.7 \times 3.175 \times 0.64 \mathrm{~mm}(0.50 \times 0.125 \times$ 0.025 in.); strain rate: $0.2 / \mathrm{min}$. 
but progressive decrease in the ductility with exposure time to air. The higher strength of the control specimen relative to the annealed specimen is suggestive of an aging reaction at $600^{\circ} \mathrm{C}$. Fig. 2.4(a) shows the microstructure of the fractured end of a specimen oxidized $1000 \mathrm{hr}$ and tested at $600^{\circ} \mathrm{C}$, and confirms the absence of any embrittlement.

Oxidation of the alloy at $800^{\circ} \mathrm{C}$ causes a reduction in the ductility at that temperature from 27 to $18.2 \%$ elongation after $1000 \mathrm{hr}$ and to $1.6 \%$ elongation after the 3042-hr exposure. Fig. 2.4(b) shows an embrittled surface zone and a ductile core after the 1000-hr exposure. Embrittlement also occurs in the specimens oxidized at $1000^{\circ} \mathrm{C}$. At this temperature, the ductility decreases from about 38 to $8.8 \%$ after a 1000-hr exposure [see Fig. 2.4(c)] and is $4.2 \%$ after $3042 \mathrm{hr}$. It is noted that the ductility of the control specimens at $1000^{\circ} \mathrm{C}$ has increased by a factor of 3 over the annealed specimen after aging. Therefore, the ductility minimum observed in annealed specimens has either shifted from its characteristic $1000-1100^{\circ} \mathrm{C}$ range or no longex exists after the thermal aging treatment in vacuum.

\subsection{2 $\mathrm{Pt}-3008 / \mathrm{ZrO}_{2}$ Compatibility $-\mathrm{H}$. Inouye}

Zirconia is often considered as a component inside of or as a structural support for noble metal capsules. Since there was some concern that the noble metal/oxide interactions observed in gettered inert gases, hydrogen, and ultrahigh vacuum ${ }^{1,2}$ might also occur between $\mathrm{Pt}-3008$ and $\mathrm{ZrO}_{2}$ in a heat-source environment, compatibility tests for this combination of materials were conducted in both helium and in vacuum.

Table 2.6 summarizes the tensile properties of $\mathrm{Pt}-3008$ specimens in the aged condition (control) and after exposure to $\mathrm{ZrO}_{2}$ in vacuum and to $\mathrm{ZrO}_{2}$ in helium. The properties of specimens annealed $1 \mathrm{hr}$ at $1200^{\circ} \mathrm{C}$ are also 1 isted to show the effects of the thermal aging treatment. The data show the following:

(a) Thermal Aging Effects - For all test temperatures, the strength of the control specimens is consistently lower than the annealed specimens. Aging had no significant effect on either the elongation or the reduction of area, except at $1316^{\circ} \mathrm{C}$. At this temperature, aging embrittles the a11oy. 

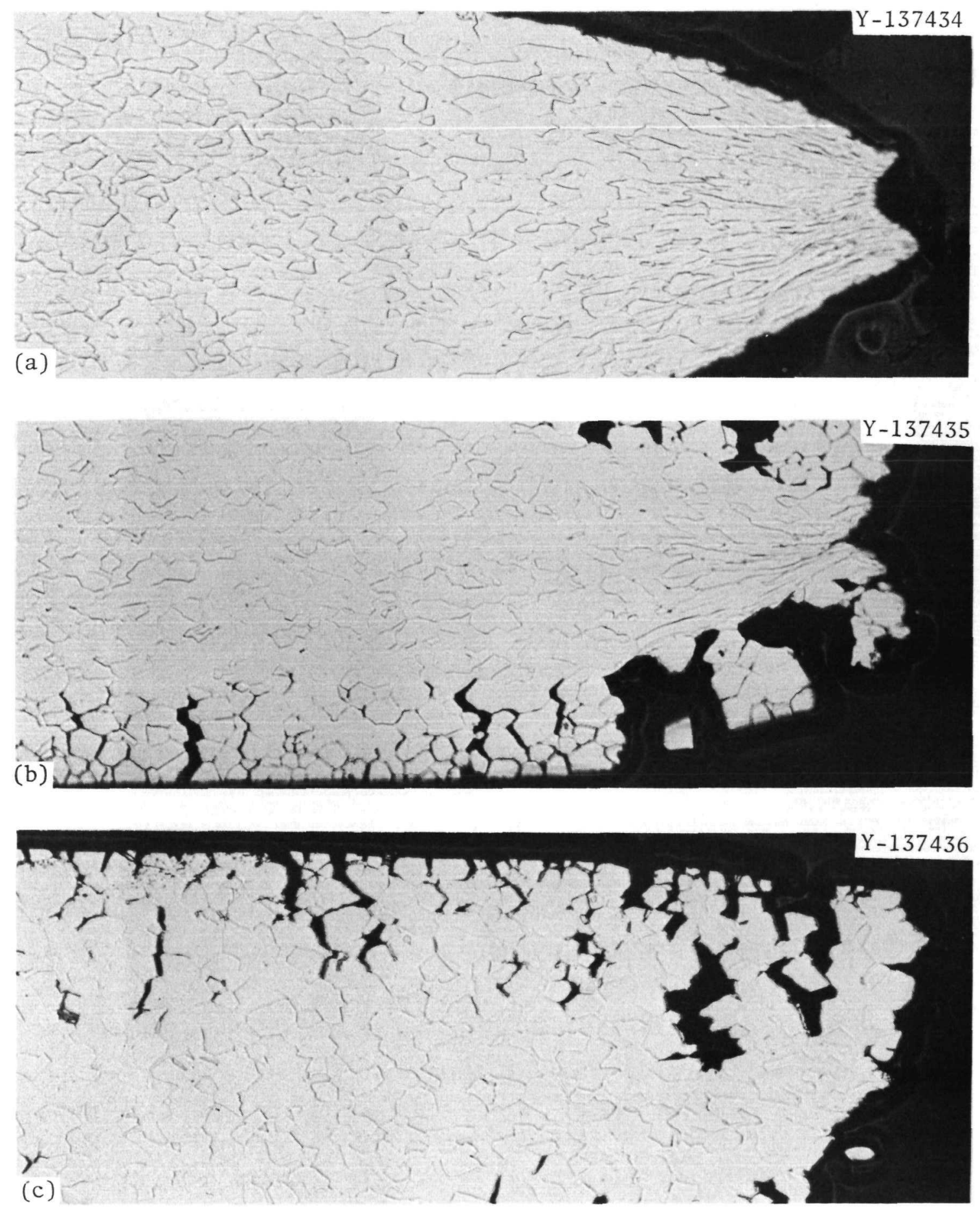

Fig. 2.4. Fractured Ends of Pt-3008 Tensile Specimens Oxidized $1000 \mathrm{hr}$ in Air and Tested at (a) $600^{\circ} \mathrm{C}$ with $32 \%$ Elongation, (b) $800^{\circ} \mathrm{C}$ with $18.2 \%$ Elongation, and (c) $1000^{\circ} \mathrm{C}$ with $8.8 \%$ Elongation. 150x. 
Table 2.6. Tensile Properties of Pt-3008 (Heat LCPT-4) Vacuum Aged and Heated in Contact with $\mathrm{ZrO}_{2}{ }^{\mathrm{a}}$

\begin{tabular}{|c|c|c|c|c|c|c|}
\hline \multicolumn{3}{|c|}{ Exposure Conditions } & \multicolumn{2}{|c|}{ Strength, MPa(ksi) } & \multirow{2}{*}{$\underset{\left(\begin{array}{l}0 \\
0\end{array}\right)}{\text { Elongation }}$} & \multirow{2}{*}{$\begin{array}{c}\text { Reduction } \\
\text { of Area } \\
(\%)\end{array}$} \\
\hline $\begin{array}{l}\text { Time } \\
(\mathrm{hr} r)\end{array}$ & $\begin{array}{l}\text { Temperature } \\
\left({ }^{\circ} \mathrm{C}\right)\end{array}$ & Environment & U1timate & $\begin{array}{l}0.2 \% \\
\text { Yield }\end{array}$ & & \\
\hline \multicolumn{7}{|c|}{$25^{\circ} \mathrm{C}$} \\
\hline 1 & 1200 & $\operatorname{Vac}$ (Annealed) & $620.1(90.0)$ & $361.0(52.4)$ & 11.2 & 12.5 \\
\hline 1007 & 1050 & $\operatorname{Vac}{\text { (Control })^{b}}^{-}$ & $511.9(74.3)$ & $292.8(42.5)$ & 10.4 & $d$ \\
\hline 1004 & 1050 & $\mathrm{ZrO}_{2}-\mathrm{Vac}^{\mathrm{b}}$ & $618.0(89.7)$ & $336.2(48.8)$ & 12.6 & 10.5 \\
\hline 1000 & 1050 & $\mathrm{ZrO}_{2}-\mathrm{He}^{\mathrm{c}}$ & $344.5(50.0)$ & $240.5(34.9)$ & 6.8 & 9.6 \\
\hline \multicolumn{7}{|c|}{$760^{\circ} \mathrm{C}$} \\
\hline 1 & 1200 & Vac (Annealed) & $567.1(82.3)$ & $214.3(31.1)$ & 27.4 & 85.1 \\
\hline 1007 & 1050 & Vac (Contro1) & $536.7(77.9)$ & $146.1(21.2)$ & 36.8 & 83.6 \\
\hline 1004 & 1050 & $\mathrm{ZrO}_{2}-\mathrm{Vac}$ & $567.1(82.3)$ & $199.1(28.9)$ & 35.4 & 90.2 \\
\hline 1000 & 1050 & $\mathrm{ZrO}_{2}-\mathrm{He}$ & $421.7(61.2)$ & $107.5(15.6)$ & 39.6 & 88.7 \\
\hline \multicolumn{7}{|c|}{$1093^{\circ} \mathrm{C}$} \\
\hline 1 & 1200 & Vac (Annealed) & $285.9(41.5)$ & $158.5(23.0)$ & 17.2 & 19.0 \\
\hline 1007 & 1050 & Vac (Control) & $246.0(35.7)$ & $112.3(16.3)$ & 12.0 & 19.9 \\
\hline 1004 & 1050 & $\mathrm{ZrO}_{2}-\mathrm{Vac}$ & $259.1(37.6)$ & $130.2(18.9)$ & 24.0 & 27.4 \\
\hline 1000 & 1050 & $\mathrm{ZrO}-\mathrm{He}$ & $212.2(30.8)$ & $68.2(9.9)$ & 28.8 & 26.1 \\
\hline \multicolumn{7}{|c|}{$1316^{\circ} \mathrm{C}$} \\
\hline 1 & 1200 & Vac (Annealed) & $150.2(21.8)$ & $121.3(17.6)$ & 40.0 & 44.2 \\
\hline 1007 & 1050 & Vac (Control) & $78.6(11.4)$ & $67.5(9.8)$ & 8.0 & 42.0 \\
\hline 1004 & 1050 & $\mathrm{ZrO}_{2}-\mathrm{Vac}$ & $143.3(20.8)$ & $108.9(15.8)$ & 41.2 & 49.5 \\
\hline 1000 & 1050 & $\mathrm{ZrO}_{2}-\mathrm{He}$ & $93.0(13.5)$ & $60.6(8.8)$ & 26.8 & 3.6 \\
\hline
\end{tabular}

${ }^{\mathrm{a}}$ Specimen gage dimensions: $12.7 \times 3.175 \times 0.64 \mathrm{~mm}(0.5 \times 0.125 \times$

0.025 in.); strain rate: $0.2 / \mathrm{min}$.

$\mathrm{b}_{\text {Pressure }}=1.3 \times 10^{-6} \mathrm{~Pa}\left(1 \times 10^{-8}\right.$ torr $)$.

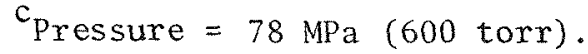

$\mathrm{d}_{\text {Specimen failed in pinhole. }}$

(b) $\mathrm{ZrO}_{2} /$ Vacuum Effects - The strength of the specimens exposed to $\mathrm{ZrO}_{2}$ are always higher than the strength of the control specimens with no indication of embrittlement. The strength increase suggests that the noble metal/oxide reaction mentioned previously might have occurred or that $\mathrm{ZrO}_{2}$ retards the thermal degradation effects discussed previously.

(c) $\mathrm{ZrO}_{2} / \mathrm{He}$ Effects - Both the ultimate and, in particular, the yield strength of the specimens exposed to the $\mathrm{ZrO}_{2} / \mathrm{He}$ environment are significantly lower than those of the control specimens, especially at 760 and $1000^{\circ} \mathrm{C}$. 
Figure 2.5 shows the microstructures resulting from the exposure of Pt-3008 to $\mathrm{ZrO}_{2}$ in vacuum and in helium. A most surprising result is the extremely large grain size of the specimen exposed to the $\mathrm{ZrO}_{2} / \mathrm{He}$ environment. This extensive grain growth is probably the reason for the large reduction in the yield strengths noted for this environment in Table 2.6. Because Fig. 2.5(b) shows no evidence of a $\mathrm{Pt}-3008 / \mathrm{ZrO}_{2}$ interaction, it appears that the higher strengths of these specimens exposed to this environment, as compared to the control specimens, are due a smaller grain size [compare Fig. 1.2(a) with Fig. 1.2(b) (p. 5 of this report) in the unstressed condition]. The specimens fail intergranularly in Fig. 1.2(a) and (c) at $1316^{\circ} \mathrm{C}$. The unusual failure mode shown in Fig. 1.2(b) results from recrystallization at or during cooling of the specimen from the test temperature.

We conclude from these relatively short-term exposures that thermal aging degrades the slow-strain tensile properties of $\mathrm{Pt}-3008$ and is aggravated when the effects of the $\mathrm{ZrO}_{2} /$ He environment are superimposed on the thermal effects. In contrast, the $\mathrm{ZrO}_{2} /$ vacuum environment appears to counteract the thermal effects and, in a sense, stabilizes the annealed properties. Because the observed effects are best explained in terms of the grain size, it is concluded that grain boundary impurities play an important role in the property changes.

\subsubsection{Pt-3008 Physical Properties $-H$. Inouye}

Moduli and Poisson's ratio vs temperature were reported previously. ${ }^{3}$ Because a value of about 0.17 for Poisson's ratio was abnormally low for metals, the measurements were repeated on a new wire specimen [2.03-mm(0.08-in.-) diam $\times 101.6-\mathrm{mm}-(4-i n .-)$ long]. The new values are plotted as a function of temperature in Figs. 2.6, 2.7, and 2.8. These data were obtained by the sonic method, as previously done, through the efforts of J. P. Hammond of the Metals and Ceramics Division, ORNL. 


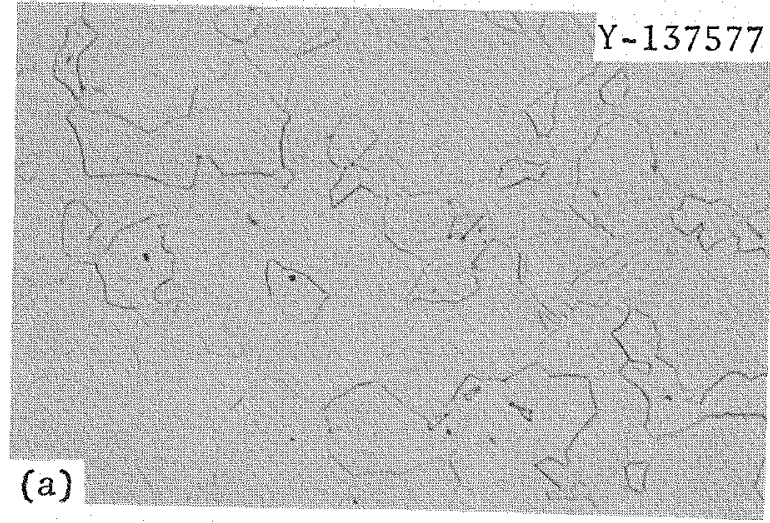

UNSTRESSED CONDITION

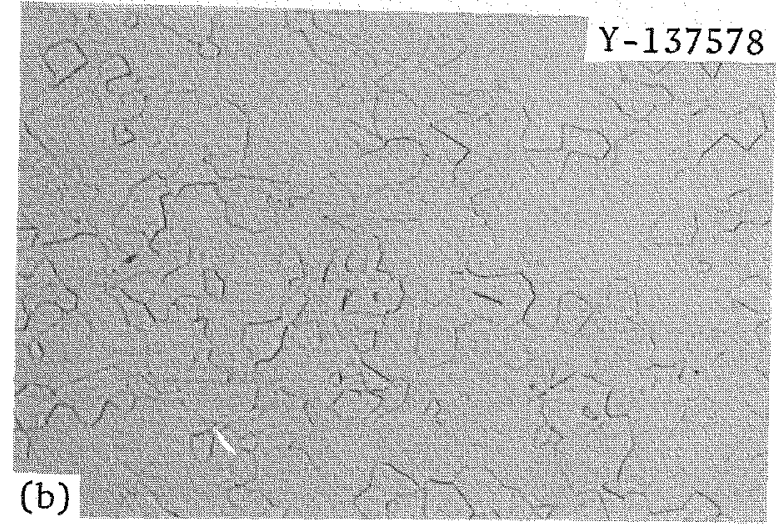

UNSTRESSED CONDITION

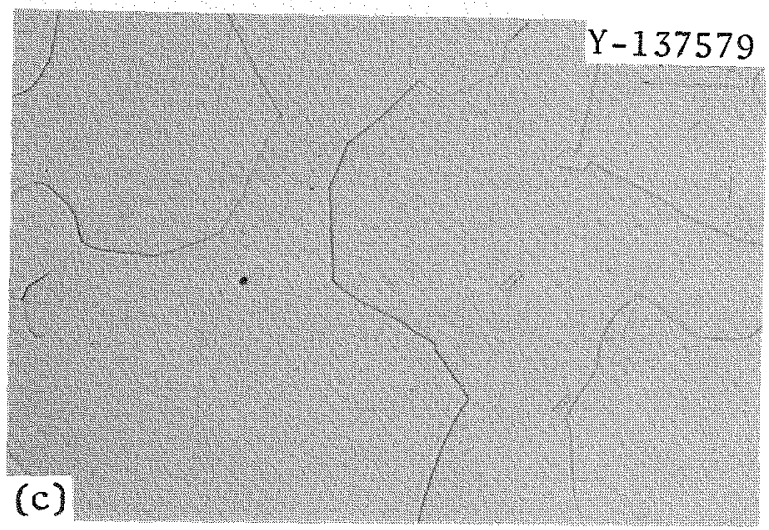

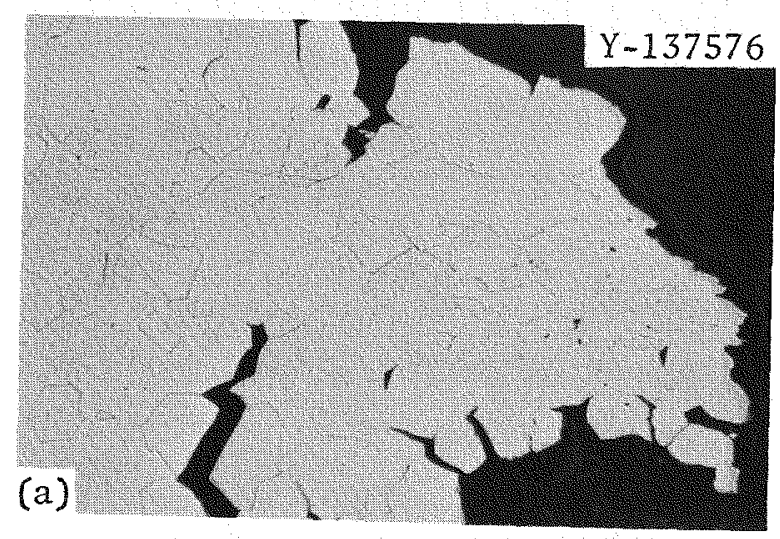

FRACTURE ENDS

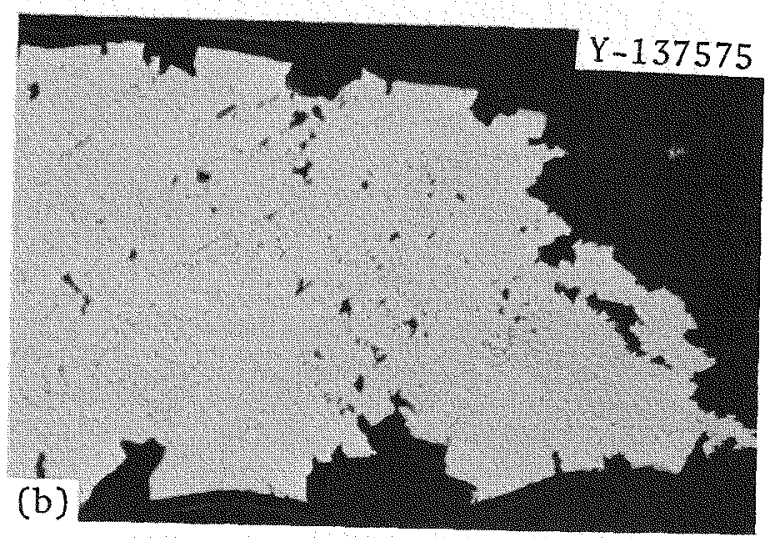

FRACTURE ENDS

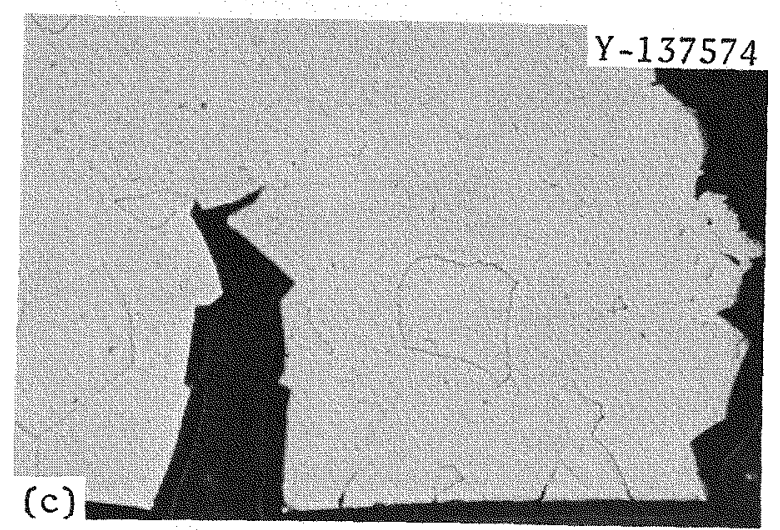

Fig. 2.5. Microstructures of $\mathrm{Pt}-3008 \mathrm{Aged} 1000 \mathrm{hr}$ at $1050^{\circ} \mathrm{C}$ and $\mathrm{Ten}-$ sile Tested at $1316^{\circ} \mathrm{C}$. (a) Control specimen; (b) $\mathrm{ZrO}_{2} /$ vacuum; and (c) $\mathrm{ZrO}_{2} /$
helium. $100 \times$. 


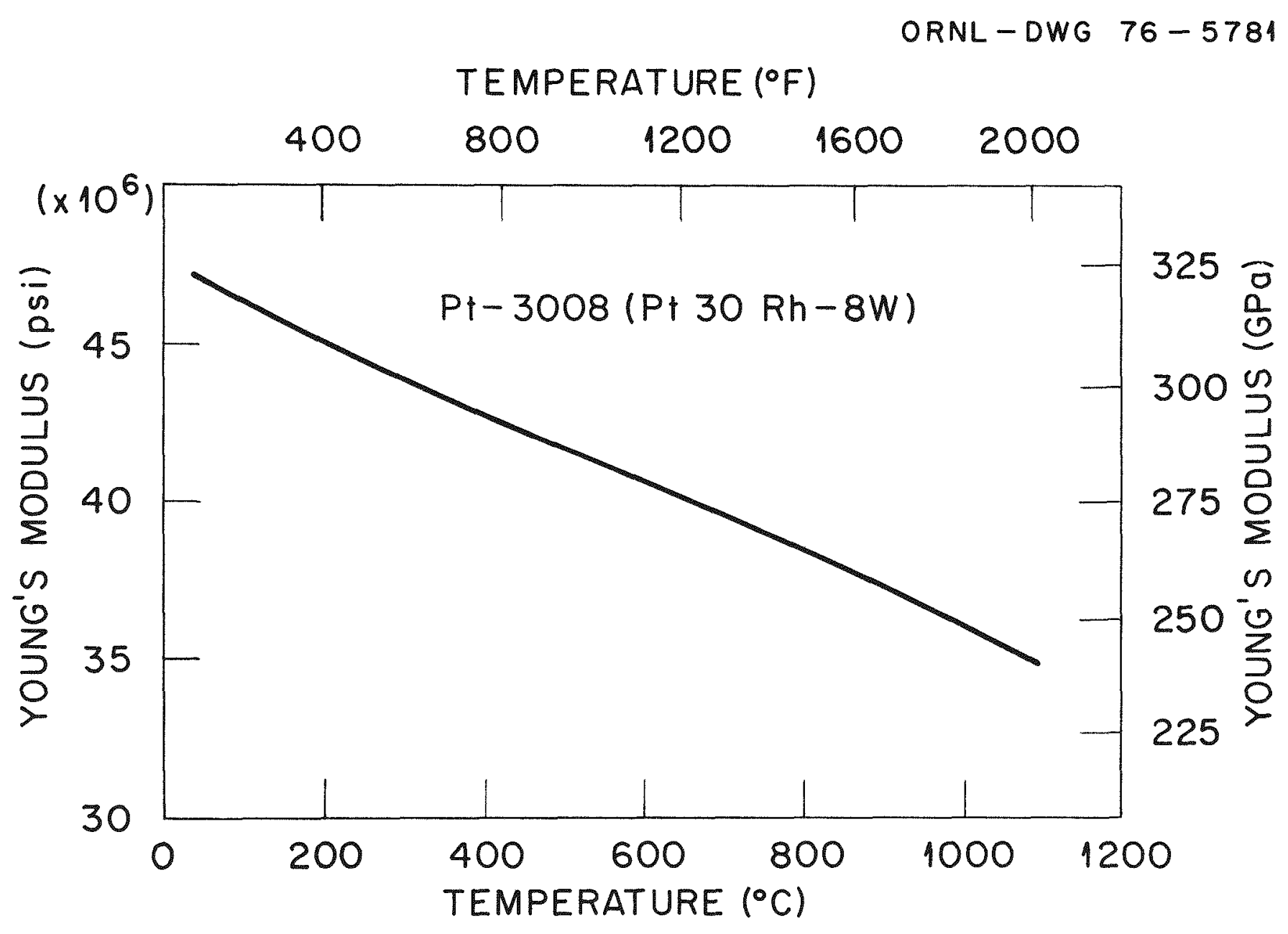

Fig. 2.6. Young's Modulus $(E)$ of Pt-3008 as a Function of Temperature. 


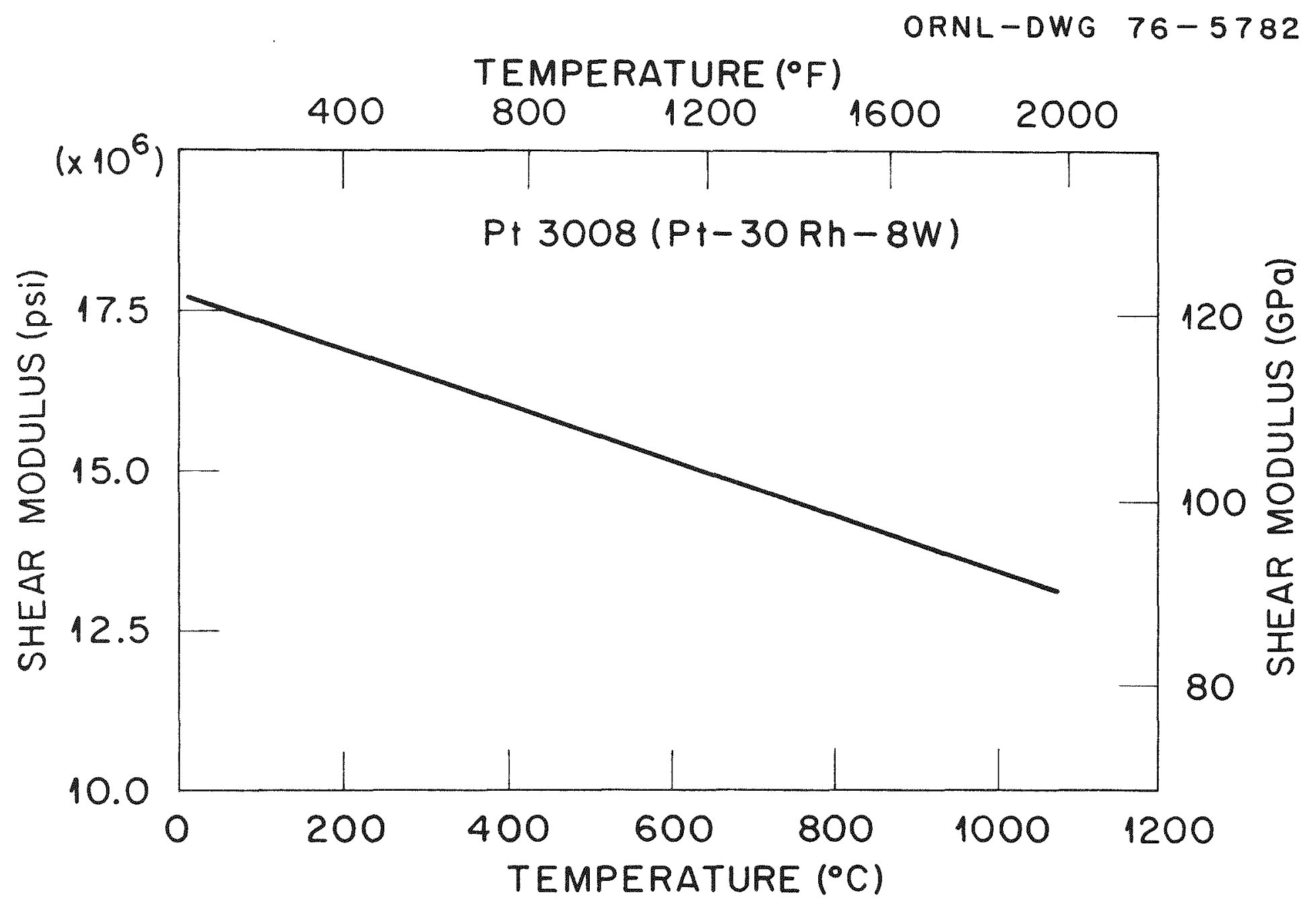

Fig. 2.7. Shear Modulus (G) of Pt-3008 as a Function of Temperature. 


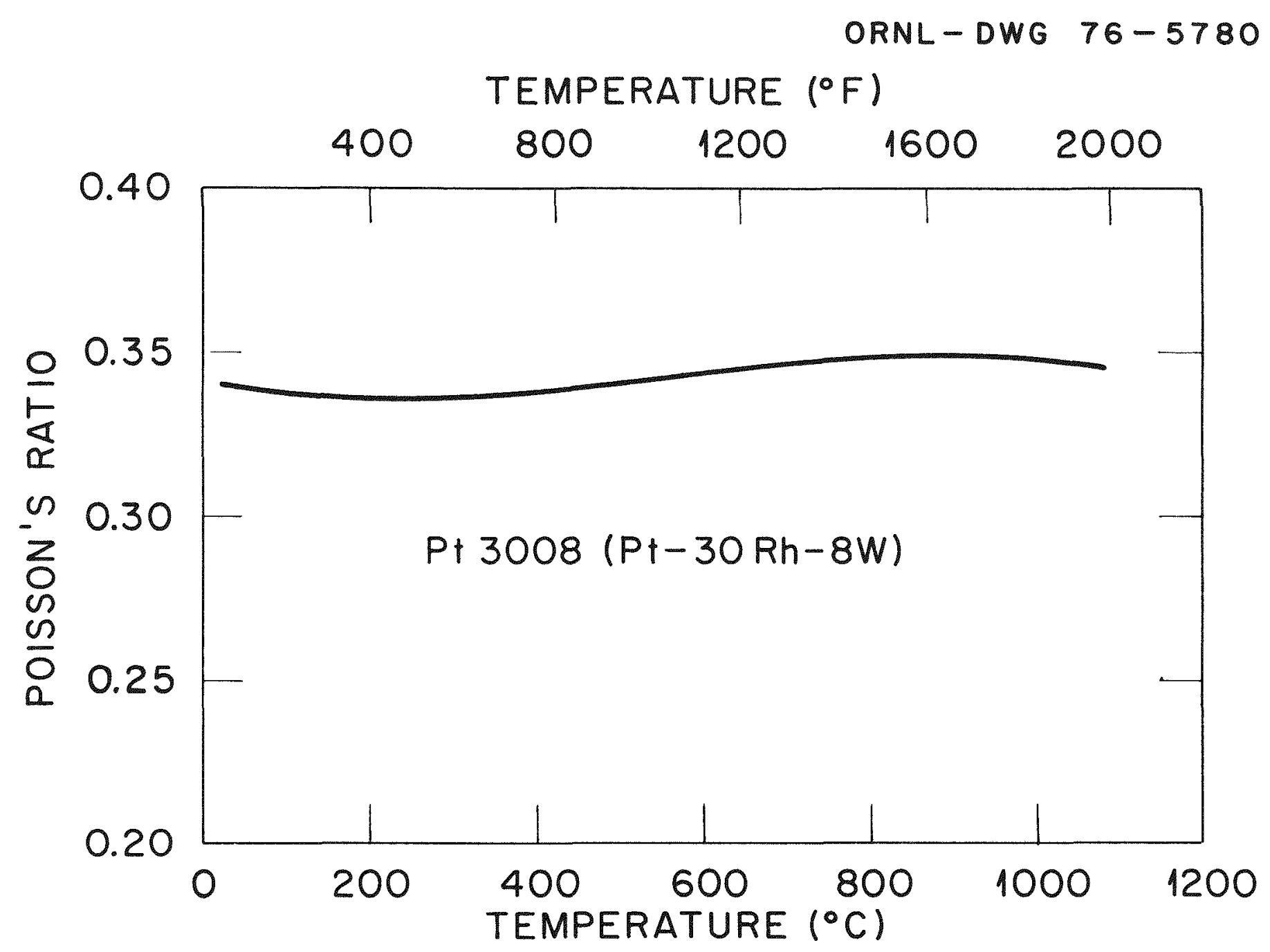

Fig. 2.8. Poisson's Ratio $(V)$ of Pt-3008 as a Function of Temperature. 


\subsection{Microanalysis Studies}

C. L. White, L. Heatherly, Jr., and R. E. Clausing

\subsubsection{The Role of Thorium in $\operatorname{Ir}-0.3 \% \mathrm{~W}$ A1loys}

The improvements in high-temperature impact performance, obtained by doping Ir-0.3\% W alloys with the DOP-4 dopants, has given rise to questions concerning the relative importance of the five dopants ( $\mathrm{Al}, \mathrm{Fe}, \mathrm{Ni}, \mathrm{Rh}, \mathrm{Th}$ ) and the mechanism(s) whereby they induce these improvements. Analysis of doped and undoped Ir-0.3\% W alloys, using Auger electron spectroscopy, have consistently indicated that thorium is the only one of the DOP-4 dopants that segregates to the grain boundaries at detectable levels. ${ }^{4-7}$

Recent impact test results on $\mathrm{Ir}-0.3 \% \mathrm{~W}$ alloys doped only with thorium showed that, except for very large grain-size samples, these alloys fail in a ductile mode with reductions of area of approximately $90 \%$. This suggests that thorium, by itself, alters the mechanical properties of the grain boundaries so that they no longer limit the high-temperature impact properties of these alloys.

Since thorium seems to be the element that directly influences the mechanical properties of the grain boundaries, a detailed study of the mechanism by which it affects these properties has been initiated.

The variation in properties with thorium content have been studied using alloys having nominal thorium concentrations between $30 \mathrm{ppm}$ (DOP-4) and $1000 \mathrm{ppm}$ (WTh-2) using AES and conventional metallographic techniques. The WTh-2 alloy contains a significant fraction of second phase (presumably $\operatorname{Ir}{ }_{5} \mathrm{Th}$ ), suggesting that the solubility of thorium in $\mathrm{Ir}-0.3 \% \mathrm{~W}$ is certainly less (probably much less) than $1000 \mathrm{ppm}$. Comparison of microstructures in alloys containing various amounts of thorium suggests that the thorium solubility in $\mathrm{Ir}-0.3 \% \mathrm{~W}$ may be less than $30 \mathrm{ppm} .^{8}$

The thorium concentration on intergranular fracture surfaces has been determined using AES for the alloys indicated in Table 2.7. The procedure for AES analysis has been described previously; ${ }^{9}$ however, the analysis of alloys containing $1000 \mathrm{ppm}$ Th (WTh-2) required a somewhat different procedure and analysis of the results. Initial AES studies of heat WTh-2 indicated approximately the same or slightly lower thorium concentrations 
Table 2.7. Alloys Examined Using

Auger Electron Spectroscopy

\begin{tabular}{|c|c|}
\hline Heat & $\begin{array}{c}\text { Thorium } \\
\text { Doping } \\
\text { Level }\end{array}$ \\
\hline 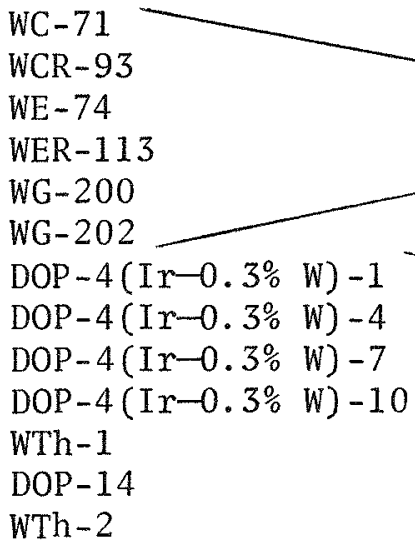 & $\begin{array}{l}\text { None } \\
30 \mathrm{ppm} \\
50 \mathrm{ppm} \\
200 \mathrm{ppm} \\
1000 \mathrm{ppm}\end{array}$ \\
\hline
\end{tabular}

on fresh fracture surfaces as compared to alloys containing lower thorium additions (DOP-4 alloys). It was also observed that, following fracture in the ultra-high vacuum (UHV) system, the oxygen AES signal increased with time, and the thorium AES signal decreased with time. The changes in the iridium signal were minimal, and the mechanism(s) responsible for these changes in oxygen and thorium signals as a function of time have not been explored. It seems reasonable, however, to suggest that the increase in oxygen signal is the result of oxygen absorption on the fracture surface. The reason for the rather larger effect of this oxygen absorption on the thorium signal than on the iridium signal is not clear. The oxygen absorption occurs in spite of vacuum system base pressures in the range of $1.3 \times 10^{-8} \mathrm{~Pa}\left(1 \times 10^{-10}\right.$ torr $)$ and the use of a liquid-nitrogen-cooled titanium sublimation pump to bring the system pressure into the range of $1.3 \times 10^{-9} \mathrm{~Pa}\left(1 \times 10^{-11}\right.$ torr $)$ while the sample is being analyzed. Thorium is, of course, a highly active element with a strong affinity for oxygen, and, hence, thorium-rich fracture surfaces might be expected to interact with the residual oxygen in the AES vacuum system more strongly than surfaces not enriched with thorium.

In order to obtain a valid indication of the thorium signal at the moment of fracture, energies between $50-75 \mathrm{eV}$ were scanned repeatedly 
following fracture of a sample of WTh-2. Starting a little more than one minute after the sample was fractured, the $54-\mathrm{eV}$ iridium peak and the $67-\mathrm{eV}$ thorium peak were recorded at 9 - and $10-\mathrm{sec}$ intervals. Approximately $7 \mathrm{~min}$ after the sample was fractured, the scan rate was reduced to allow the peaks to be recorded at $40-\mathrm{sec}$ intervals. Figure 2.9 shows the results of these measurements for several time intervals up to $30 \mathrm{~min}$ after the sample was fractured. The decrease in the thorium peak height relative to the iridium peak height is easily observed. The thorium peak height is plotted as a function of time (after fracture) in Fig. 2.10. The heights of individual peaks are represented as dots in Fig. 2.10 while crosses indicate the average thorium peak height over a 2 -min interval centered about the point, and squares indicate the average thorium peak height in a 10-min interval centered about the point. Extrapolation of the data in Fig. 2.10 to the moment of fracture $(t=0)$ suggests a thorium peak height in the neighborhood of $14 \mathrm{~mm}(1 / 2 \mathrm{in.})$. The iridium (54 eV) peak height at the moment of fracture is estimated to be about $153 \mathrm{~mm}$ ( 6 in.), yielding a ratio of thorium (67 eV) to iridium (54 eV) peak heights $(R)$ of about 0.0915 . Figure 2.11 shows the variation of $R$ with the thorium doping level for alloys studied thus fax. The right axis in Fig. 2.11 also indicates the estimated atomic percent thorium to be associated with each point.* While there is some scatter in the data, and while uncertainty remains about how much of the thorium that is added to the alloys is retained after melting, the data suggests that for doping in the range $30-1000 \mathrm{ppm} \mathrm{Th}$, the concentration of thorium at the grain boundaries does not change significantly.

A series of low thorium (5-25 ppm) Ir $-0.3 \% \mathrm{~W}$ alloys is being prepared in order to study the effect of bulk thorium content on high-temperature impact properties and grain boundary chemistry. We will be particularly interested in determining the minimum doping level of thorium that will result in acceptable high-temperature impact properties for alloys of any given grain size. Since we know that significant changes in grain boundary chemistry and impact properties occur with the addition of $30 \mathrm{ppm}$ Th, the

\footnotetext{
*The atomic percent thorium indicated in Fig. 2.10 is estimated by assuming that our analysis is approximately 4.4 times as sensitive to the thorium as iridium and ignoring other elements on the fracture surfaces.
} 


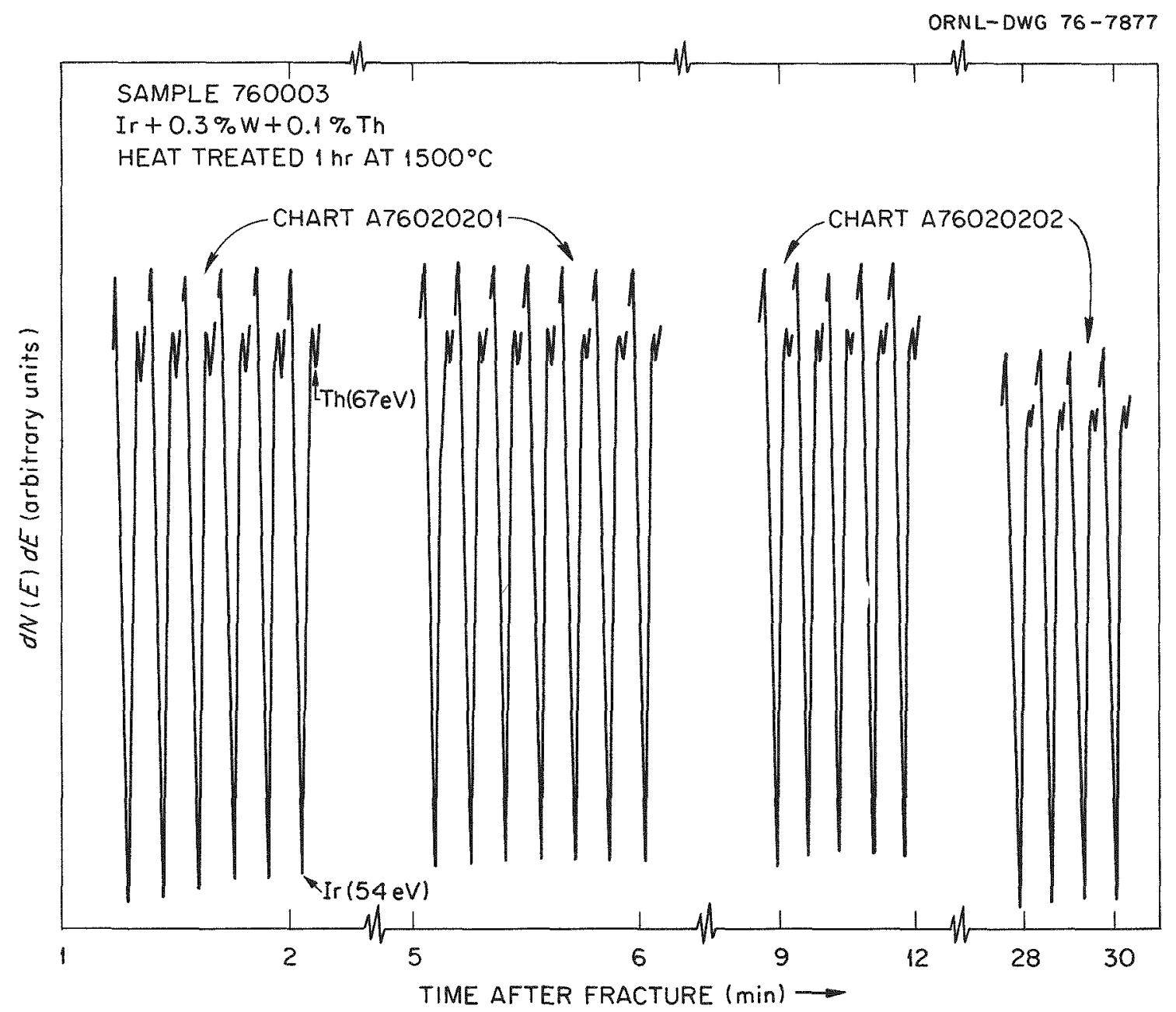

Fig. 2.9. Partial Auger Spectra of WTh-2 Showing the Iridium (54 eV) and Thorium $(67 \mathrm{eV})$ Peaks as a Function of Time. Several time intervals up to $30 \mathrm{~min}(1800 \mathrm{sec})$ are shown. 


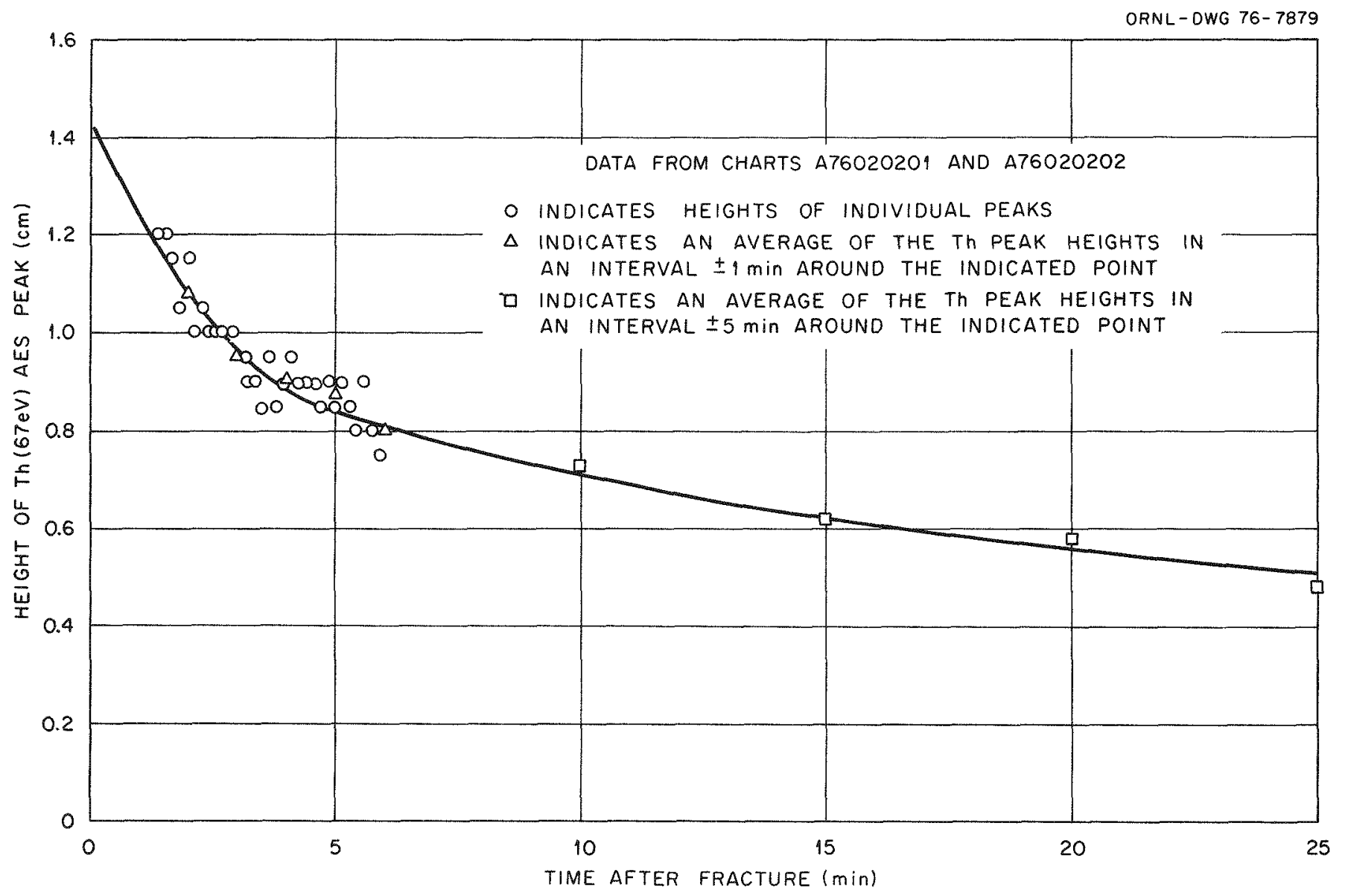

Fig. 2.10. Variation in the Thorium $(67 \mathrm{eV})$ Peak Height as a Function of Time after Fracture. 
ORNL-DWG $76-7878$

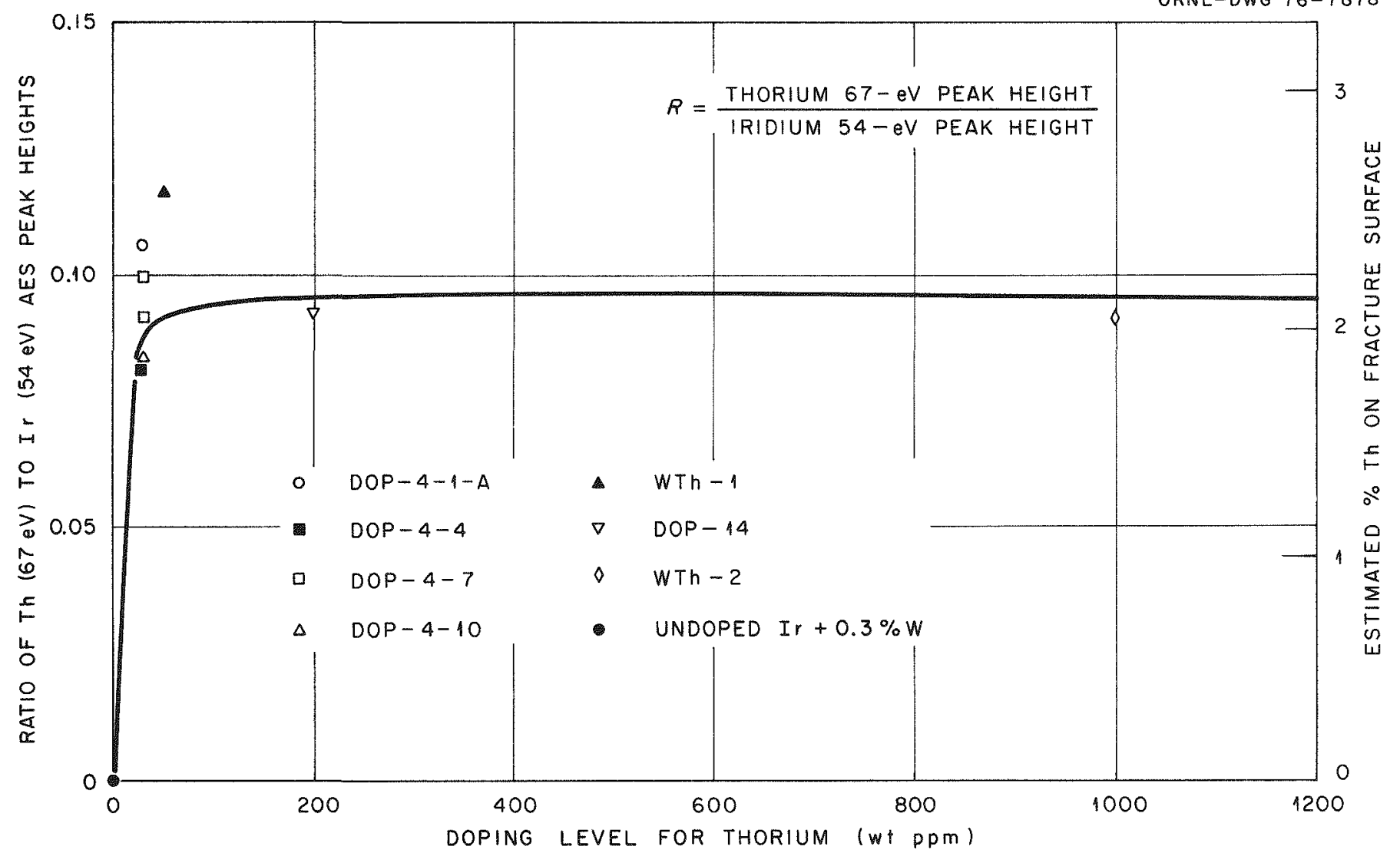

Fig. 2.11. Variation in Grain Boundary Thorium Concentration (Determined by Auger Electron Spectroscopy) as a Function of the Bulk Thorium Doping Level. 
study of these low-thorium alloys may give insight into the mechanism(s) responsible for these changes. Additional understanding of these mechanisms could result in the selection of better dopants or dopant combinations. Samples of heat WTh-2 (Ir-0.3\% W-0.1\% Th) have been examined by W. H. Christie* using ion microprobe mass analysis (IMMA). This technique has the advantage of being able to detect very small concentrations (in the ppm range) of certain elements in areas as sma11 as a few micrometers. The sample of WTh-2 had a $1 \mathrm{hr}$ at $1500^{\circ} \mathrm{C}$ heat treatment and was prepared for metallographic examination. The metallographic sample was then analyzed using IMMA. The mass spectrum of the sample indicated the presence of Ir, $W$, Th, and $U$, with the uranium concentration about one-twentieth that of thorium.

Rastering the ion beam to allow mapping of the various elements over the surface indicated the thorium to be concentrated in the small precipitates that are easily seen in WTh-2. There was some indication that the precipitates are somewhat richer in tungsten than the matrix material; however, more work will be necessary in order to establish this with confidence.

The sample of WTh-2 is being reground and repolished so that IMMA can be obtained on a sample with a surface that has not been etched, in case the etching removes the material of interest in the analysis.

\subsubsection{Phosphorus Contamination and Embrittlement of Grain Boundaries in $\operatorname{Ir}-0.3 \%$ W A1loys}

Evidence has been reported previous $1 y^{8}$ that indicates phosphorus contamination of the Ir $-0.3 \% \mathrm{~W}$ cladding material may be occuring in single sphere FSA impacts (using a thorium fuel simulant). Limited evidence is also available ${ }^{8}$ that suggests that phosphorus contamination could lead to serious degradation of the high-temperature impact performances of these alloys.

Material from fuel sphere MHT-45 (made from EI lot 86 iridium) has recently been examined using AES, and the results appear to be consistent with those reported by others. ${ }^{10}$ A fresh intergranular fracture surface appeared to have about 5 at. $\% \mathrm{P}$ on it, and sputtering less than 10 atom layers using $\mathrm{Ar}^{+}$removed all traces of the phosphorus.

\footnotetext{
*Analytica1 Chemistry Division at ORNL.
} 
Methods of contaminating Ir $-0.3 \% \mathrm{~W}$ alloys with controlled amounts of phosphorus are currently being evaluated in order to provide material for studying the effect of phosphorus on the impact properties and grain boundary chemistry of these alloys.

\subsubsection{Grain Boundary Analysis of Pt-3008 Alloys}

Samples of Pt-3008 alloy from heats LCPT-32-4, LCPT-9-6, and LCPT-4-3 have been analyzed using Auger electron spectroscopy. Heat LCPT-32-4 has been reported to have good ductility (elongation is $40.2 \%$ ) at $1093^{\circ} \mathrm{C}$, while LCPT-9-6 and LCPT-4-3 have been reported to have significantly lower ductilities (elongations of 15 and $17 \%$, respectively). AES analysis of these alloys indicated that heat LCPT-9-6 had a grain-boundary phosphorus contamination of about 1.5 at. $\%$ while heats LCPT-32-4 and LCPT-4-3 had about 0.5 at. $\% \mathrm{p}$ at the grain boundaries. In addition to the phosphorus, each of these alloys had small, but detectable concentrations of silicon on them. LCPT-32-4 and LCPT-9-6 had approximately 2 at. $\%$ Si at the grain boundaries, while LCPT-4-3 had about half that amount. Inert ion sputtering experiments indicated that both phosphorus and silicon were preferentially segregated to the fracture surfaces.

\subsection{Special Projects}

\subsubsection{Effects of Thermal Aging on the Mechanical Properties of Superalloys for Isotope Containment - J. P. Hammond}

During the past quarter, the evaluation of the effects of 1 ong-term thermal aging $(11,000 \mathrm{hr})$ at $816^{\circ} \mathrm{C}\left(1500^{\circ} \mathrm{F}\right)$ on the tensile properties of four isotopic containment superalloys (Haynes 25, Haynes 188, Haste1loy N, and Inconel 625) was completed. In the last quarterly progress report, ${ }^{11}$ the results for the first three aforementioned materials was reported. The present report gives the tensile test results for Inconel 625 , tensile test toughness values for all four alloys, the results of phase identification studies, and endeavors to explain the tensile test findings. The chemical analyses of the alloys and details of the methods of test were given in the last quarterly progress report. ${ }^{11}$ 
2.5.1.1 Tensile Test Results on Inconel 625. - The tensile test results for Inconel 625 in the usual graphical form are given in Fig. 2.12. Results for two Haynes 25 alloys ( 0.1 and $0.36 \% \mathrm{Si}$ ), Haynes 188 , and Hastelloy $\mathrm{N}$, which were presented in the last quarterly, ${ }^{1}$ showed longterm aging at $816^{\circ} \mathrm{C}$ not to have a very large effect on the tensile and yield strengths but to substantially influence the amount of total elongation. For room-temperature tests, elongations were depreciated in amounts from $74 \%$ (Hastelloy $N$ ) to $86 \%$ [Haynes 25 (0.36\% Si)]. Figure 2.12 shows that aging Inconel 625 significantly lowers its yield strength for the lower test temperatures. Total elongation at room temperature again was significantly reduced from the solution-annealed value, but not to nearly so great an extent $(33 \%)$ as for the other alloys. As in the case of the Haynes 25 and Haynes 188 alloys, a reversal in the extent of total elongation at the ductility minimum temperature was obtained for Inconel 625 . Whereas at approximately $704^{\circ} \mathrm{C}\left(1300^{\circ} \mathrm{F}\right)$ Inconel 625 in the solutionannealed condition displays its lowest ductility (about 40\%), an unexpected high value was obtained in this temperature region in the aged condition (Fig. 2.12). At still higher test temperatures, ductility increased to enormous values, which is characteristic solely of Inconel 625. Because ductility of all of the aged superalloys was quite high at approximately $760^{\circ} \mathrm{C}\left(1400^{\circ} \mathrm{F}\right)$, a temperature at which yield and tensile strengths had not begun to drop off very greatly, we surmised that the aged alloys would reflect high toughness values at this temperature. Consequently, the tensile data were analyzed to establish toughness response.

\subsubsection{Tensile Toughness of Superalloys. - Toughness values were} determined for the aged alloys at the ultimate and fracture tensile stresses by establishing areas under the engineering stress-strain graphs by the Johnson integration method. The results are presented in the form of bar charts in Fig. 2.13. The individual charts give energies to ultimate and fracture stress for tests successively at $24,316,760$, and $982^{\circ} \mathrm{C}$.

Significantly, in the case of all the aged cobalt-base alloys, highest toughnesses were obtained at $760^{\circ} \mathrm{C}$ (the temperature of the ductility minimum for the solution-annealed condition). These values proved 2 to 3 times higher than for the other test temperatures. Interestingly, the bar charts 

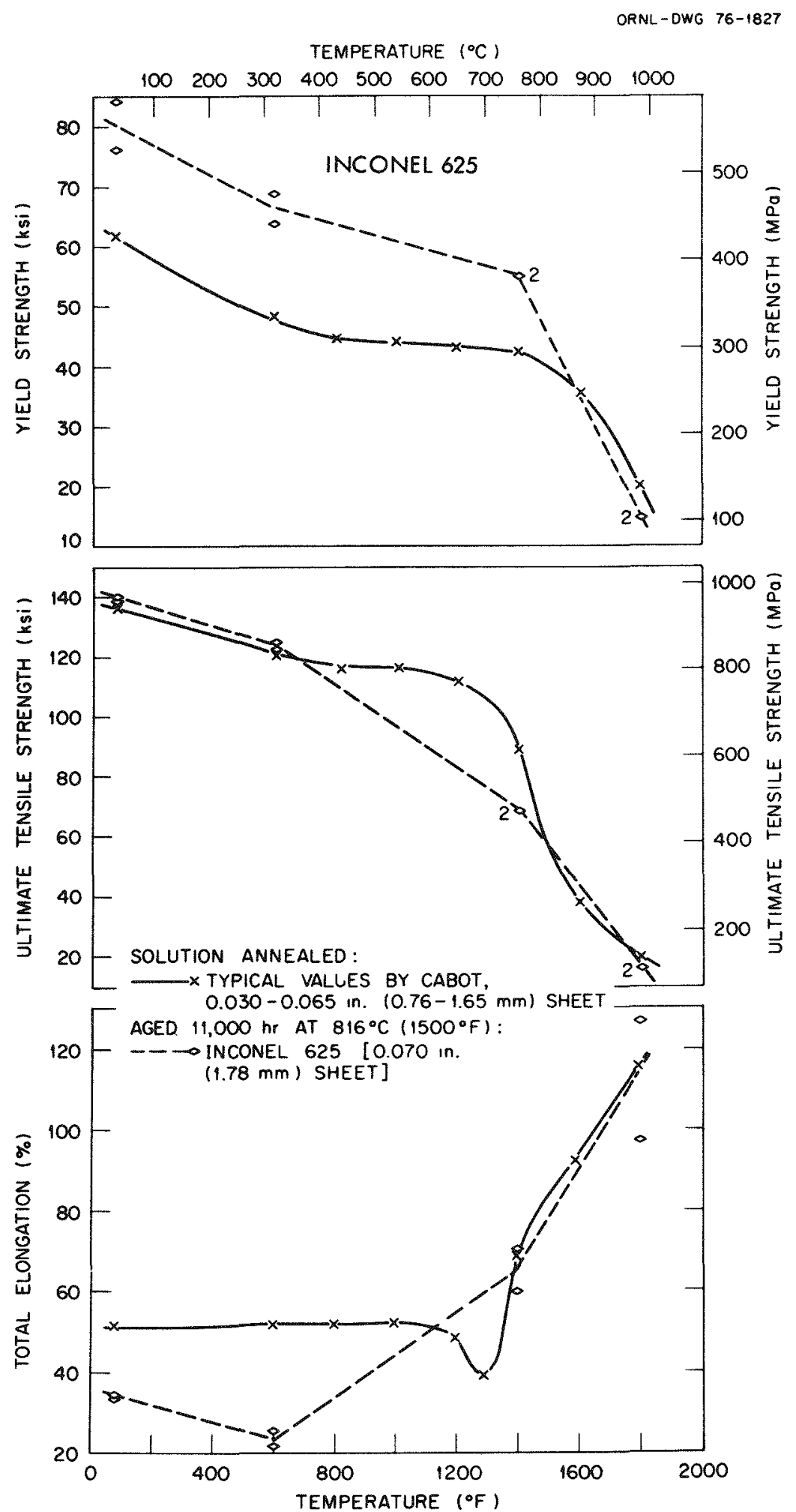

Fig. 2.12. Comparisons Between Effects of Solution-Annealed and Aged Conditions on the Yield Strength, U1timate Strength, and Total Elongation of Inconel 625 . 
ORNL-DWG 76-1912

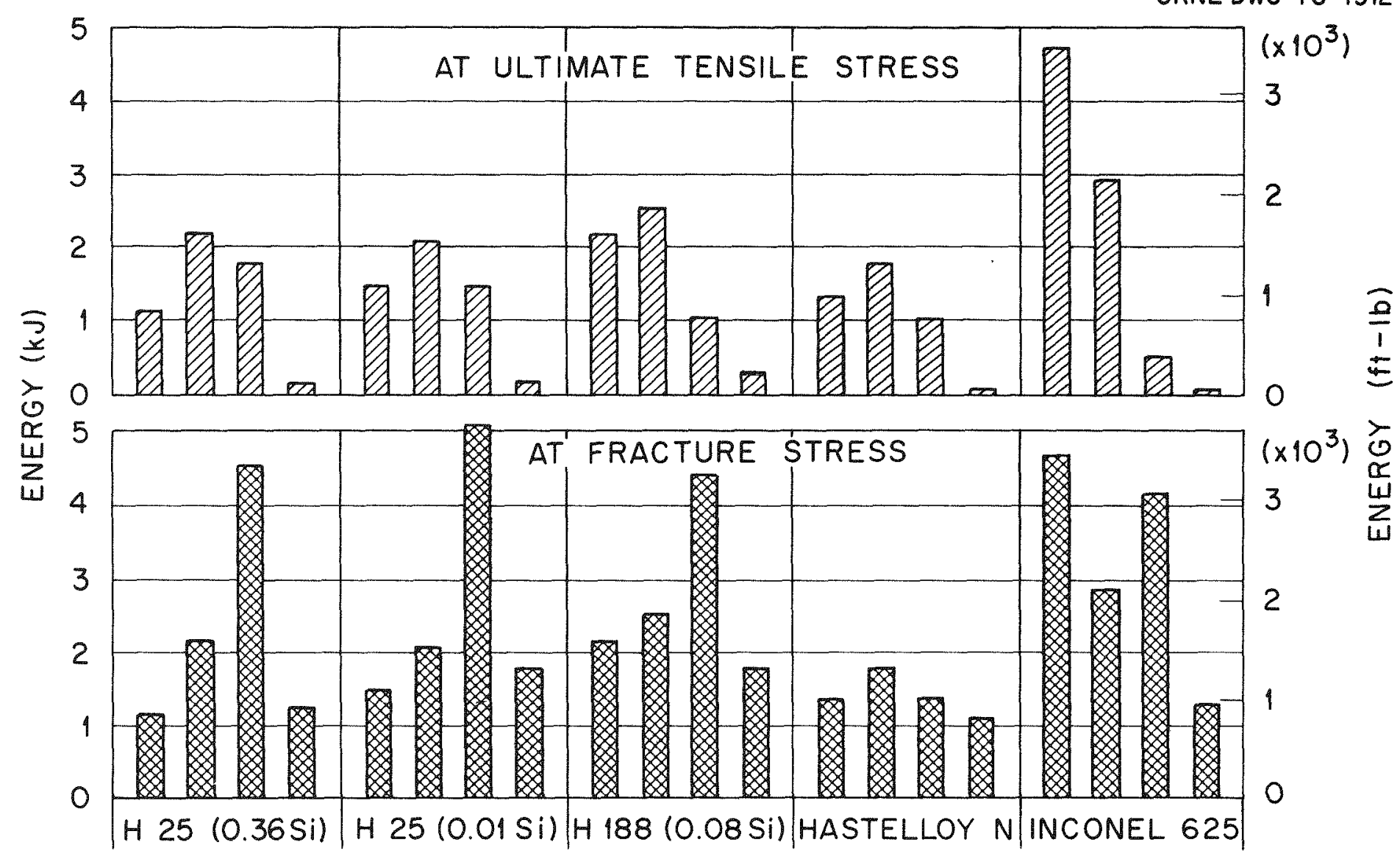

Fig. 2.13. Energy of Deformation at Ultimate Tensile and Fracture Stress for Alloy Tested in Aged Condition. (Bar charts for individual alloys give average of two values at $24,316,760$, and $982^{\circ} \mathrm{C}$, consecutively.) 
for the individual cobalt-base alloys are similar, reflecting similar metallurgy. The individual charts for the two nickel-base alloys (Hastelloy $\mathrm{N}$ and Inconel 625), on the other hand, are different. The toughness values obtained for Hastelloy $\mathrm{N}$ are comparatively low. Inconel 625 gave the highest toughnesses for tests at room temperature which also were higher by far than the room-temperature toughnesses of the other alloys.

The reversal in ductility response of aged cobalt-base alloys at the temperature of their ductility minimum was unexpected and was not previously reported. These findings suggest that overaged cobalt-base alloys and Inconel 625 may exhibit impressive toughness at temperatures around $760^{\circ} \mathrm{C}$, as well as good strength and ductility. The aged Inconel 625 alloy should show like advantages at room temperature.

2.5.1.3 Fractography of Fracture Surfaces and Identification of Phases. The microstructures of the individual aged alloys at the location of fracture after tensile testing at $316^{\circ} \mathrm{C}$ were reported in the last quarterly progress report. ${ }^{11}$ Additional metallographic examinations after tests at the other temperatures, together with electron-beam scans on the fracture surfaces, gave the following results.

Fractures on all of the aged superalloys tested at room temperature were intergranular in mode except in the cast of Inconel 625, which had a transgranular fracture. On the other hand, for the $760^{\circ} \mathrm{C}$ test temperature (location of ductility minimum for solution-annealed condition), the fractures of the aged superalloys were predominantly transgranular in character except in the case of Hastelloy $\mathrm{N}$, which gave a definite intergranular failure. The type of fracture observed for the individual alloys at room temperature correlated directly with the microstructures. For example, Inconel 625 had a fine dispersion of disconnected precipitate platelets with little or no concentration of precipitates in grain boundaries. The cobalt-base alloys had brittle precipitates of a semi-continuous nature in grain boundarics, while Hastelloy $\mathrm{N}$ displayed a massive precipitate of more continuous character in grain boundaries.

The fracture results on specimens tested at $760^{\circ} \mathrm{C}$ could be only partially explained by the metallographic results and will be commented on further below. The results of the electron-beam scans corroborated the 
metallographic findings. Scans on Inconel 625 which was fractured at room temperature showed highly ligamented topology, suggestive of ductility and transgranular mode of fracture and even more so for the fractures associated with the 760 and $892^{\circ} \mathrm{C}$ tests. The scans of fractures of the Haynes 25 alloys tested at room temperature indicated intergranular fracture mode and little or no ductility. On the other hand, the fracture surface associated with this aged alloy after testing at $760^{\circ} \mathrm{C}$ displayed the cone-in-cup feature, characteristic of ductile failure. The fracture mode was predominantly transgranular.

The phases that precipitated in the aged superalloys were separated from the shoulders of tensile specimens pulled at $316^{\circ} \mathrm{C}$ by electrolysis and identified by $x$-ray diffraction. The results are listed below in Table 2.8.

Table 2.8. Precipitates Formed in Superalloys at $816^{\circ} \mathrm{C}$

$$
\text { By Yukawa et } \alpha z^{12}
$$

Haynes 25: $\mathrm{M}_{7} \mathrm{C}_{3} \rightarrow\left[\underline{\left.\mathrm{M}_{23} \mathrm{C}_{6}\right]} \rightarrow \underline{\mathrm{M}_{6} \mathrm{C}} \rightarrow \underline{\text { Laves } \mathrm{CO}_{2} \mathrm{~W}} \rightarrow \mu \mathrm{Co}_{7} \mathrm{~W}_{6}\right.$

$$
\text { By Herchenroeder et } a Z{ }^{13}
$$

Haynes 188: $\left[\mathrm{M}_{6} \mathrm{C}\right] \rightarrow \mathrm{M}_{23} \mathrm{C}_{6} \rightarrow$ Laves $\mathrm{Co}_{2} \mathrm{~W}$

$$
\text { After } 11,000 \mathrm{hr}^{\mathrm{a}}
$$

Haynes $25,0.36 \%$ Si: Laves $\mathrm{Co}_{2} \mathrm{~W}(S) ; 4$ lines $^{\mathrm{b}}(S)$ 14.5 wt $\%$

Haynes 25, 0.01\% Si: 14.8 wt \% Haynes 188: Laves $\mathrm{Co}_{2} \mathrm{~W}(V S) ; 2$ Iines $^{\mathrm{b}}(M)$ 15.2 wt $\%$ Hastelloy $\mathrm{N}: \quad(\mathrm{Mo}, \mathrm{Ni})_{12} \mathrm{C}$ $5.0 \mathrm{wt} \%$

The information at the top of the table shows the secondary phases that appear with increasing time of aging at around $816^{\circ} \mathrm{C}$, according to previous investigations. The phases contained in the brackets are the primary carbide constituents incorporated in the alloys for retarding grain growth with metal working and heat treatment. The underlined phases contribute to strength at $816^{\circ} \mathrm{C}$ by coherency hardening. The data in the right-hand column at the bottom gives the amount of secondary constituent electrolytically separated from the test specimens based on total metal removed. 
Observe from the data that the amount of precipitate formed with aging the individual cobalt-base alloys is about equal. This, together with the metallographic data, indicated that silicon level had little influence on the resulting aged microstructures. Judging from the relatively large amounts of the Laves $\mathrm{Co}_{2} \mathrm{~W}$ phase found in the aged Haynes 25 and Haynes 188 alloys, it appears that the aging process was well along after $11,000 \mathrm{hr}$ at $816^{\circ} \mathrm{C}$. Since this phase is reported to confer brittleness ${ }^{13}$ to structural alloys containing it, it is reasonable that the cobalt-base alloys tested at room temperature should display little ductility. The precipitate formed in aged Hastelloy $\mathrm{N}$ was shown to be $(\mathrm{Mo}, \mathrm{Ni})_{12} \mathrm{C}$. This phase had not been previously reported in Hastelloy $\mathrm{N}$.

Because calculations based upon simplifying assumptions indicated that the matrices of the aged cobalt-base alloys may have as much as half of their tungsten depleted as a result of forming tungsten containing precipitates, an electron probe analysis was made of the aged Haynes 25 alloy $(0.36 \% \mathrm{Si})$. Using tungsten metal as a standard, repeated isolation probe analyses were conducted on the matrix of the aged specimen and compared to ones made on a like alloy in the solution-annealed condition. These tests indicated that $11,000-\mathrm{hr}$ aging at $816^{\circ} \mathrm{C}$ depleted the matrix of approximately one-third of its tungsten content. Further, set scans made of the matrix of the aged alloy indicated even tungsten concentrations as opposed to a denuding effect, although this must be taken with caution since resolution of the probe beam was no better than about $5 \mu \mathrm{m}$. Tungsten $\mathrm{M}^{\propto} \mathrm{x}$-ray displays made of various fields of view in the aged alloy also failed to show denuding. Again, however, resolution was not high. Such tungsten x-ray displays conducted on this alloy in the solution-annealed condition revealed the primary carbide constituent of the alloy solution annealed to contain a substantial amount of tungsten (perhaps $50^{\circ}$ ). This was not expected.

\subsubsection{Rationalization of Ductility and Toughness Results. - The} results of the ductility curves for all of the aged superalloys are incorporated in a single illustration with information on mode of fracture with at room temperature, 760 , and $982^{\circ} \mathrm{C}$ included therein in Fig. 2.14. Mode of fracture for the solution-annealed condition was taken from the work of Rhines and Wray. ${ }^{14}$ According to their generalized model on plastic 


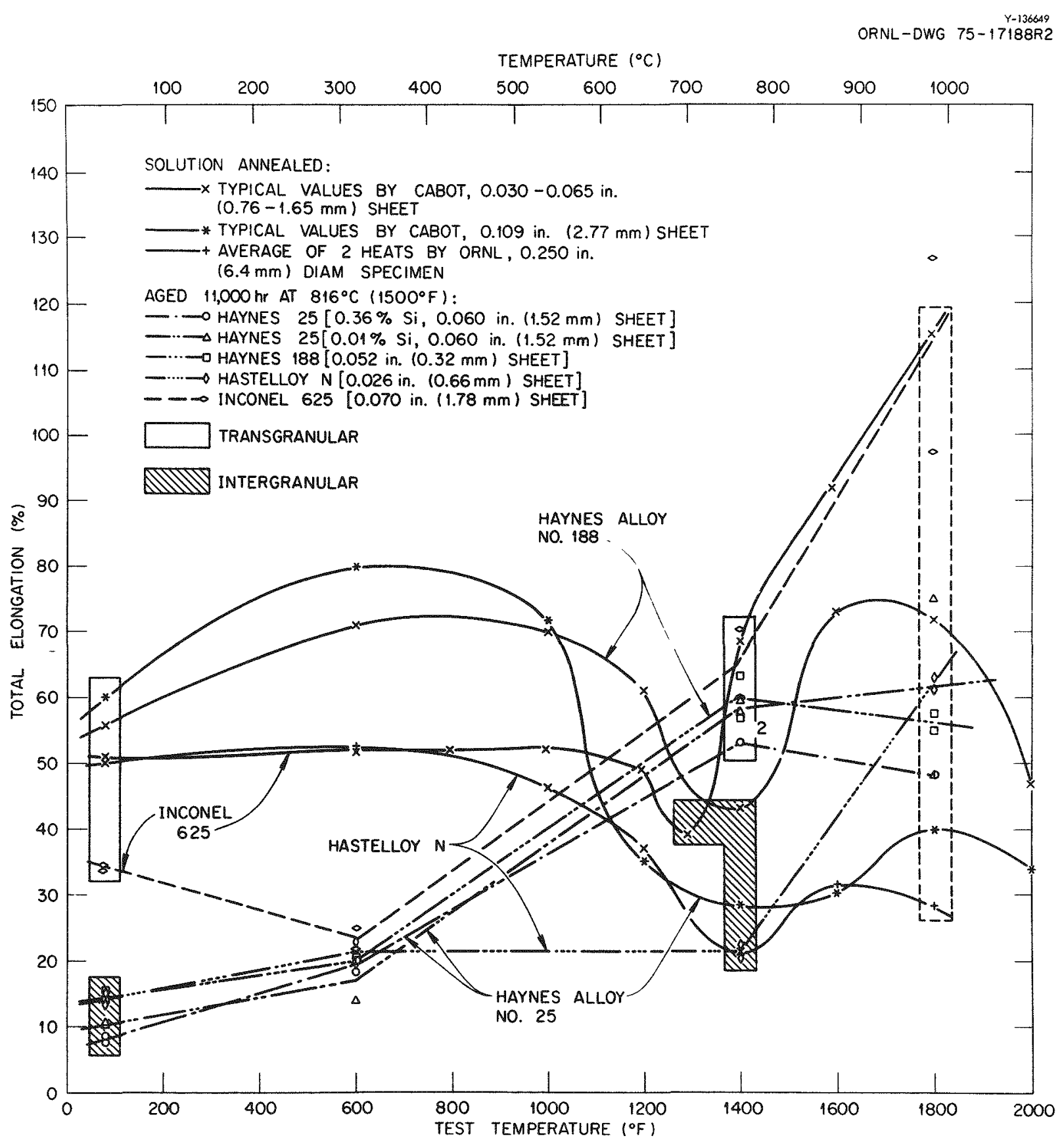

Fig. 2.14. Correlation of Ductility Response with Fracture Mode.

behavior, all ductile metals and solution-annealed superalloys should show a ductility minimum at elevated temperatures. They postulate at low temperatures, fracture occurs by the usual transgranular crack propagation mechanism, and ductility is high. At temperatures near the minimum, deformation occurs by grain boundary shear, and the intergranular voids formed 
at triple points grow unhindered, causing intergranular fracture with drastic loss in ductility. At high temperatures, recrystallization occurs simultaneously with intergranular void formation, continuously breaking up the intergranular fracture path. As a result, ductility increases again.

Observe from Fig. 2.14 that overaging of the solution-annealed superalloys resulted in a reversal in the fracture mode as well as a complete inversion of the ductility response. Moreover, high ductility appears to equate with transgranular mode of failure, and low with intergranular. The transgranular mode of fracture for all alloys in both conditions at $982^{\circ} \mathrm{C}$ is indicated by the dashed enclosure because all alloys in the aged condition were not examined at this temperature. Whether or not an alloy at a very high temperature fails intergranularly would appear to depend upon the extent to which grain boundaries are weakened by proximity to melting temperature.

The fact that the aged superalloys gave high ductility and predominantly transgranular mode of fracture at the temperature of the ductility minimum was not expected. Since the test specimens, after a11, contained ostensibly the same internal microstructures that gave brittle, intergranular fractures in these materials at room temperature, explanations of why are in order. Three factors appear to be involved.

Usually, the ductility minimum behavior in its most accentuated form is associated with age hardenable alloys in their solution-annealed condition. As the alloy is hot worked or pulled, a profuse precipitation of carbides occurs at grain boundaries and along deformation bands. In the case of the present overaged alloys, potential for precipitation of secondary phases in the temperature region in question was completely spent and so there was no opportunity for precipitation embrittlement. This helps explain why the overaged alloys failed to display the ductility minimum but not why these aged alloys display high ductility at $760^{\circ} \mathrm{C}$ as contrasted to the low at room temperature. It is likely that embrittling phases, such as Laves $\mathrm{Co}_{2} \mathrm{~W}$, are not as brittle at $760^{\circ} \mathrm{C}$ as at room temperature. Lastly, the observed tungsten depletion effect that accompanied overaging is possibly involved. Because these particular cobalt-base alloys are dependent upon tungsten additive for their elevated-temperature strength via substitutional solute hardening, its depletion from the matrix could possibly result in improved elevated-temperature plasticity. 


\subsection{References}

1. J. E. Selle, J. R. McDouga1, and D. R. Schaffer, The Compatibility of Plutonizm-238 Dioxide with Platinum and Platinum-Rhodium Alzoys: Interim Report, MLM-1684 (January 30, 1970).

2. A. S. Darling, G. L. Selmon, and R. Rushford, "Platinum and the Refractory Oxides," Platinum Met. Rev. 14(2): 54-60 (1970); 14(3): 95-102 (1970); 14(4): 124-30 (1970); 15(1): 13-8 (1971).

3. R. G. Donne1ly, Isotopic Power Materials Development Progress Report for May 1975, ORNL-TM-4983.

4. R. G. Donnelly, Isotopic Power Materials Development Progress Report for November 1974, ORNL-TM-4795, p. 21.

5. R. G. Donnel1y, Isotopic Power Materials Development Progress Report for January 1975, ORNL-TM-4859, p. 20.

6. R. G. Donne11y, Isotopic Power Materials Development Progress Report for February 1975, ORNL-TM-4890, p. 20.

7. Internal memorandum, C. L. White to R. G. Donnelly, May 13, 1976.

8. A. C. Schaffhauser, Isotopic Power Materials Development Quart. Progr. Rep. Dec. 31, 1975, ORNL/TM-5285.

9. R. G. Donne11y, Isotopic Power Materials Ann. Progr. Rep. June 30, 1975, ORNL-TM-5116.

10. R. D. Baker, Pu-238 Fuel DeveZopment Progrom and the Advanced Safety Technology Program Monthly Progress Report for January 1975, CMB-2176, pp. $22-30$.

11. A. C. Schaffhauser, Isotopic Power Materials Development Quart. Progr. Rep. Dec. 31, 1975, ORNL/TM-5285, pp. 53-71.

12. N. Yukawa and K. Satô, "The Correlation Between Microstructure and Stress Rupture Properties of a Co-Cr-Ni-W (HS-25) Alloy," Trans. Japan Inst. Metals 9: 680-6 (Supplement), (1968).

13. R. B. Herchenroeder, R. J. Matthews, J. W. Tackett, and S. J. Wlodek, Haynes AZZoy No. 188, Cobalt No. 54 (March 1972), pp. 3-13.

14. F. N. Rhines and P. J. Wray, "Investigation of the Intermediate Temperature Ductility Minimum of Metals," Trans. ASM 54: 117-28 (1961). 
Blank 


\section{ISOTOPE BRAYTON SYSTEM MATERIALS SUPPORT**}

\subsection{Introduction}

The objective of this program is to characterize the metallurgical and mechanical properties of materials and components selected for the Brayton Isotope Power System (BIPS) under the environmental and operating conditions expected for this system. Currently, emphasis is on the potential materials problems identified in the BIPS Ground Demonstration System (GDS), scheduled for operation in 1977 . These potential materials problems include the effect of contaminants on the creep properties and tensile ductility of $\mathrm{C}-103(\mathrm{Nb}-10 \% \mathrm{Hf}-1 \% \mathrm{Ti}-0.7 \% \mathrm{Zr})$ in the heat exchanger, ducting, and turbine plenum; effects of aging and thermal cycling on the properties of $\mathrm{C}-103 /$ Hastelloy $\mathrm{X}$ bimetallic joints; and the mechanical properties of braze alloys used for fabrication of the Hastelloy $X$ recuperator. The magnitude of these potential materials problems and possible solutions are being investigated. Characterization of other key components including ducting and bellows will be performed. Additional tasks such as investigation of alternate materials and long-term creep tests will be initiated as required to insure the reliability of a flight system, scheduled for 1981 .

\section{$3.2 \mathrm{C}-103 /$ Gaseous Interactions}

H. Inouye and C. T. Liu

The helium-xenon environment within the closed-cycle loop of the BIPS and the vacuum environment external to it is expected to contain low levels of gaseous contaminants that could react with and degrade the mechanical properties of the structural components. The principal objectives of this study are (a) to determine as early as possible the feasibility of using C-103 as a prime structural component in BIPS environment, (b) to establish a data base to allow an estimate of the acceptable impurity limits for using C-103, and (c) to investigate methods to minimize or avoid the deleterious gas/metal reactions (e.g., gettering and substitution of less impurity-sensitive alloys).

${ }^{*}$ Progress on work performed under Activity No. KJ 3001022 , 189a No. 00006 . 
The gaseous contaminants in the BIPS environment have not been ident $i$ fied; however, it is possible that the species and their concentration could approach that found in the helium coolant in gas-cooled reactors (Table 3.1). These gases are expected to be oxidizing and carburizing toward $\mathrm{C}-103$ in the temperature range $700-1000^{\circ} \mathrm{C}$. Previous work shows that $\mathrm{T}-111$ is severe $1 y$ embrittled at test temperatures up to $1000^{\circ} \mathrm{C}$ by absorption of a few hundred ppm oxygen. 1

Table 3.1. Impurity Levels in Helium-Cooled Gas-Cooled Reactors ${ }^{2}$ (in $\left.\mu-a t m\right)^{a}$

\begin{tabular}{|c|c|c|c|c|c|c|}
\hline Reactor & $\mathrm{H}_{2}$ & $\mathrm{H}_{2} \mathrm{O}$ & $\mathrm{O}_{2}$ & $\mathrm{CO}$ & $\mathrm{CO}_{2}$ & $\mathrm{CH}_{4}$ \\
\hline Dragon $^{b}$ & 20 & 1 & $<1$ & 10 & 0.4 & 3 \\
\hline Peach Bottom ${ }^{c}$ & 200 & $<10$ & - & 10 & - & 15 \\
\hline NGT (est) ${ }^{d}$ & 20 & $<1$ & $<1$ & 10 & $<1$ & 20 \\
\hline $\begin{array}{r}{ }^{\mathrm{a}} \text { Conversi } \\
\mathrm{b}_{\text {Typical }} \\
\text { (graphite) }\end{array}$ & $\begin{array}{r}11 \\
\text { yses } \\
\text { go }\end{array}$ & $\begin{array}{l}0.1 \\
\text { ystem } \\
\text { eratu }\end{array}$ & $\begin{array}{l}6> \\
\text { atir } \\
00^{\circ} \mathrm{C}\end{array}$ & $\begin{array}{l}\text { tor } \\
20\end{array}$ & $\mathrm{He}$. & \\
\hline
\end{tabular}

$\mathrm{d}_{\text {Nuclear Gas Turbine. General Electric Company estimate. For }}$ a system operating at $70 \mathrm{~atm}$ and a gas temperature of $\sim 815^{\circ} \mathrm{C}$.

The effect of contaminating gases on the creep of T-111 tubing was determined using an existing environmental creep apparatus while components and specimens were being fabricated for testing of $\mathrm{C}-103$ sheet specimens. The data given in Table 3.2 show that measurable strains occur when contaminants are present at pressures as low as $1.3 \times 10^{-3} \mathrm{~Pa}\left(1 \times 10^{-5}\right.$ torr $)$, but not at pressures of $1.3 \times 10^{-6} \mathrm{~Pa}\left(1 \times 10^{-8}\right.$ torr $)$. Figure 3.1 indicates that the absorption of oxygen by unstressed T-111 is accompanied by dilation of the same magnitude as shown in Table 3.2. Therefore, these preliminary data indicate that absorption of oxygen was primarily responsible for the observed strains and that creep contributed little, if any, to the overa11 strains of T-111. Because $\mathrm{C}-103$ is expected to be chemically equivalent to $\mathrm{T}-111$, the environmental effects discussed above for $\mathrm{T}-111$ may also be applicable to C-103. Modification of the environmental creep 
Table 3.2. The Effect of the Environment on the Creep of $\mathrm{T}-111^{\mathrm{a}}$ at $1000^{\circ} \mathrm{C}$ and $15.2 \mathrm{MPa}(2.2 \mathrm{ksi})$

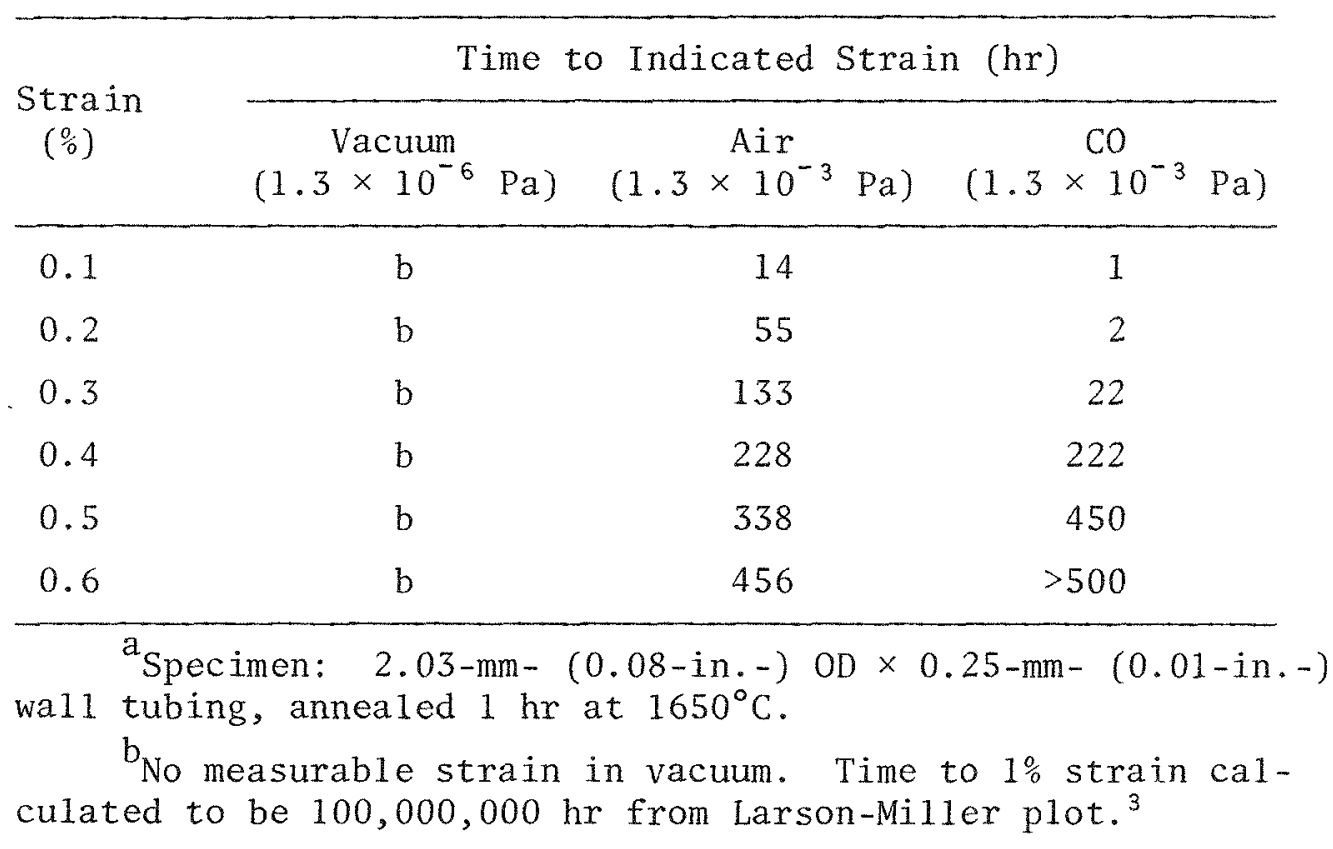




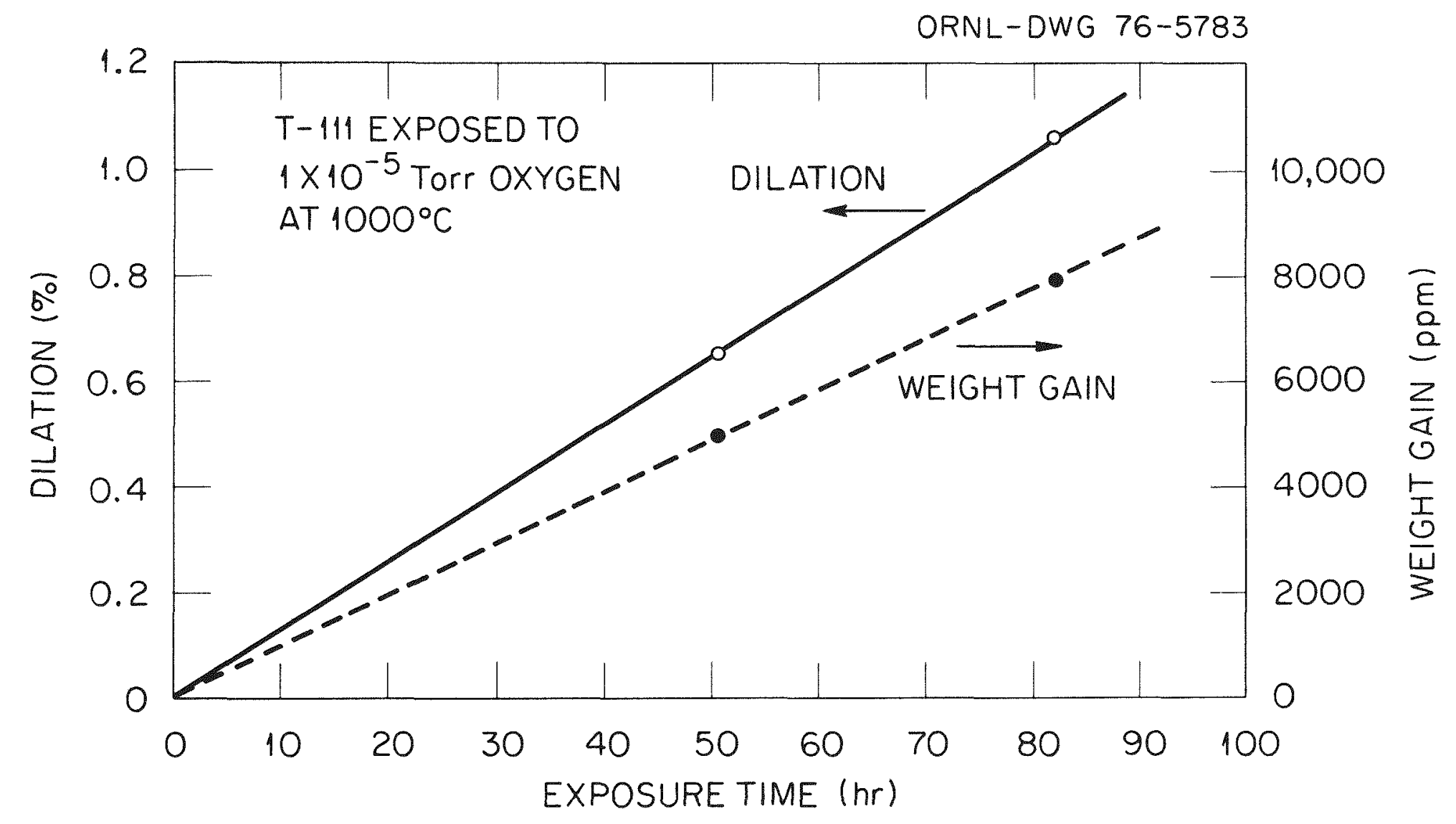

Fig. 3.1. Correlation Between Oxygen Contamination and Dilation of Unstressed T-111 Tubing. 
apparatus in which the above tests were conducted has been completed and testing of $\mathrm{C}-103$ sheet specimens under conditions applicable to the BIPS is being initiated.

Specimens of $\mathrm{C}-103$ have been exposed to $1.3 \times 10^{-3} \mathrm{~Pa}\left(1 \times 10^{-5}\right.$ torr $)$ $\mathrm{CO}$ at $1000^{\circ} \mathrm{C}$ for times to $2000 \mathrm{hr}$, and tensile tests and dilation measurements are in progress.

\subsection{A1ternate A1loys}

H. Inouye and C. T. Liu

Stress-rupture and creep tests of molybdenum-rhenium a1loys and Pt-3008 are planned for the next quarter to determine if they can be considered as alternate structural materials for $\mathrm{C}-103$. Sheet specimens of $\mathrm{Mo}-33 \% \mathrm{Re}$, Mo-46\% Re, and $\mathrm{Pt}-30 \% \mathrm{Rh}-8 \% \mathrm{~W}$ have been fabricated for creep testing at $1000^{\circ} \mathrm{C}$.

\subsection{Welding and Brazing Evaluation \\ G. M. Goodwin}

Review of the current status of critical components requiring welding and brazing development for the Isotope Brayton System was completed. The status of bimetallic joint development and testing was reviewed at NASA's Lewis Research Center on December 15, 1975. On the basis of metallographic examination and tensile tests of extensive screening samples and specimens aged $1000 \mathrm{hr}$ at $1350^{\circ} \mathrm{F}$, the direct braze of $\mathrm{C}-103$ to Hastelloy $\mathrm{X}$ using the CM-50 alloy and the $\mathrm{W}-\mathrm{Ni}-\mathrm{Fe}$ graded transition joint brazed to $\mathrm{C}-103$ with CM-50 and welded to Hastelloy $X$ appears most promising. However, NASA has no plans for longer-term aging or microprobe analysis on these samples to determine the extent of interaction.

NASA has also fabricated excellent full-size bimetallic tube samples for thermal cycling tests using the $\mathrm{CM}-50$ direct braze and transition joint processes using four different joint geometries. However, their planned thermal cycle tests may not be representative of thermal cycle these joints will experience in the Ground Demonstration System (GDS). 
Also, the bimetallic joints were made using $\mathrm{Nb}-1 \% \mathrm{Zr}$ pipe rather than $\mathrm{C}-103$ because of availability. The possibility of hafnuim intermetallic phases forming in the bimetallic joints with $\mathrm{C}-103$ resulting in poor thermal cycle performance should be investigated.

The status of recuperator fabrication and testing was also reviewed. The current design modifications and less severe thermal ramp should minimize the internal leaks in the core and manifold splitter during thermal cycle testing of the prototype unit. There appear to be sufficient mechanical properties data on the Palniro 1 braze alloy used for the core. However, there is minimal elevated temperature data on the Palniro 7 braze alloy used for manifold-to-side plate braze. This braze is critical because it is a structural joint to contain the pressure of the working fluid and is a potential external leak path.

We have received the required materials and have initiated specimen preparation for bimetaliic joint and recuperator braze alloy studies. Brazing alloys, including Coast Metals 50 ( $\mathrm{Ni}-3.5 \% \mathrm{Si}-2.5 \% \mathrm{~B}-\mathrm{I} \% \mathrm{Fe}$ ) in powder form, and Palniro $7(\mathrm{Au}-8 \% \mathrm{Pd}-22 \% \mathrm{Ni})$ in wire and sheet form, have been procured from commercial sources. Tee-joint specimens are being prepared of Hastelloy $X$ to Hastelloy $X$ using Palniro 7 (recuperator application) and Hastelloy $x$ to $C-103$ alloy with Coast Metals 50 (transition joint application). Lap-shear specimens will subsequently be prepared for shortterm tensile tests and aging studies.

\subsection{References}

1. C. T. Liu H. Inouye and R. W. Carpenter, "Structure and Mechanical Properties of Internally Oxidized T-111," Met. Trans. 4: 1839-50 (1973).

2. 0. G. Woike, SmaZZ Nuclear Process Heat Plants (SNPH) Using Pebble Bed Reactor, GEEST 75-001, ORNL-Sub-4352-1 (September 1975), p. 13-16.

3. J. B. Conway and P. N. Flagella, Creep Data for Refractory Metals to High Temperatures, GEMP-685 (March 1969). 


\section{SPACE NUCLEAR FLIGHT SYSTEMS HARDWARE}

\subsection{Introduction}

The limited-scale production of high-quality iridium alloy sheet and foil, based on ORNL-developed procedures, is performed in this task. Forming disks are machined from sheet and are supplied to Mound Laboratory for hot hydroforming into hemispheres which encapsulate the ${ }^{238} \mathrm{PuO}_{2}$ isotope fuel spheres and serve as the Post-Impact Containment She11s (PICS) of the Multi-Hundred Watt (MHW) Heat Source. Iridium alloy foil is also supplied for forming weld shields and decontamination covers during processing the PICS. Extensive quality assurance and characterization of material, along with a limited amount of process improvement development, is performed in this task.

\subsection{Production of Ir $-0.3 \%$ W Forming Disks and Foil D. E. Harasyn}

\subsubsection{Forming Disks}

Production data for Ir-0.3\% W forming disks from January through March 1976 are shown in Table 4.1. Microscopic delaminations in all metallographic samples from the lot HD 427-432 resulted in a nonconformance. Production was halted while an investigation into the cause of the delaminations was carried out. Although the cause has not been isolated, the microscopic delaminations did not affect the formability of a sample hemisphere hydroformed by Mound Laboratory nor did they result in unacceptable impact properties as discussed in section 4.3 of this report. Therefore, production has begun again as directed by ERDA-NRA. Our new schedule calls for shipment of 80 disks to MRC by the middle of May in order to complete the MJS mission. We foresee no scheduling problems in meeting the deadline, but a significant number of the 80 disks are expected to have the same type of surface delaminations as seen in HD $427-432$.

\footnotetext{
No. 00003.

${ }^{*}$ Progress on work performed under Activity No. KJ $3001032,189 a$
} 
Table 4.1. PICS Production Data

\begin{tabular}{|c|c|c|c|c|c|c|c|c|c|}
\hline \multirow{3}{*}{$\begin{array}{l}\text { Ingot } \\
\text { Number }\end{array}$} & \multirow{3}{*}{$\begin{array}{l}\text { Number } \\
\text { Machined }\end{array}$} & \multicolumn{4}{|c|}{ Nonconformance Report ${ }^{a, b}$} & \multirow{2}{*}{\multicolumn{3}{|c|}{$\begin{array}{l}\text { Disks } \\
\text { Shipped }\end{array}$}} & \multirow{3}{*}{$\begin{array}{l}\text { Date } \\
\text { Shipped }\end{array}$} \\
\hline & & \multicolumn{4}{|c|}{ Disk Number } & & & & \\
\hline & & 1 & 2 & 3 & 4 & 1 & 3 & 4 & \\
\hline HD -427 & 4 & & & U & & 1 & 1 & 1 & $1 / 29 / 76$ \\
\hline $\mathrm{HD}-428$ & 4 & U & $\mathrm{U}$ & & & & 1 & 1 & $1 / 29 / 76$ \\
\hline HD-429 & 4 & & & & & 1 & 1 & 1 & $1 / 29 / 76$ \\
\hline $\mathrm{HD}-430$ & 4 & & & & & 1 & 1 & 1 & $1 / 29 / 76$ \\
\hline$H D-431$ & 4 & & & $\mathrm{U}$ & U & 1 & 1 & & $1 / 29 / 76$ \\
\hline $\mathrm{HD}-432$ & 4 & & $\mathrm{U}$ & & & 1 & 1 & 1 & $1 / 29 / 76$ \\
\hline TOTAL DISKS & SHIPPED PER LOT: & 18 & & CUMULATIVE & E TOTAL OF & DISKS & KS SHIPPEI & E THIS & QUARTER: 18 \\
\hline
\end{tabular}


The surface delaminations are typically $0.1 \mathrm{~mm}(0.004 \mathrm{in.})$ in length and 1 ess than $0.01 \mathrm{~mm}$ (0.0004 in.) below the ground surface and usually cannot be seen at magnifications less than 200x. The largest delaminations are about $0.4-\mathrm{mm}(0.16-\mathrm{in}$.$) long. Figure 4.1$ shows some typical delaminations found in longitudinal cross sections of test disks taken from HD 427-432. A spot check made on the next lot of sheets, HD 433-438, also revealed surface delaminations. The delaminations all run parallel to the wrought, fibrous structure of the metal. However, optical microscopy cannot give us any details of the fractured surface such as the presence of second phase particles and intergranular or transgranular fracture. In the production samples shown in Fig. 4.1, there are roughly 5-10 defects per centimeter of sample. Experimental samples prepared after HD 427-432 do not contain as many defects as severe as those in Fig. 4.1.

Metallographic examination is the only method we have so far of confirming the presence of the surface delaminations. The defects are too small to be detected by dye-penetrant, ultrasonic, or visual examination of the as-ground surface with or without the aid of optics. Apparent defects in the ground surface of $\mathrm{HD}-428$, \#1 (an ultrasonic reject) have been found by using scanning electron microscopy (see Fig. 4.2). However, we have not yet been able to correlate defects in the ground surface with the surface delaminations shown in Fig. 4.1. Moreover, there is no data base against which we can compare the photos in Fig. 4.2.

In order to determine the cause of the surface delaminations, we first have to determine at which point in the production process they first appear. The most probable processes which initiate the defects are (1) surface grinding, (2) sample cutting, and (3) metallographic preparation. Rolling and casting have been discounted because surface delaminations have not been detected in as-rolled sheet samples taken from the lots in question. 
$Y-137328$

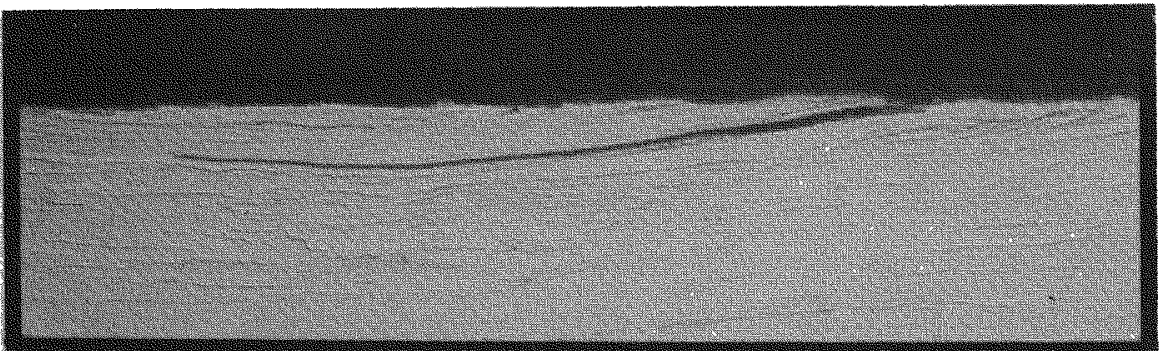

HD $427 P$

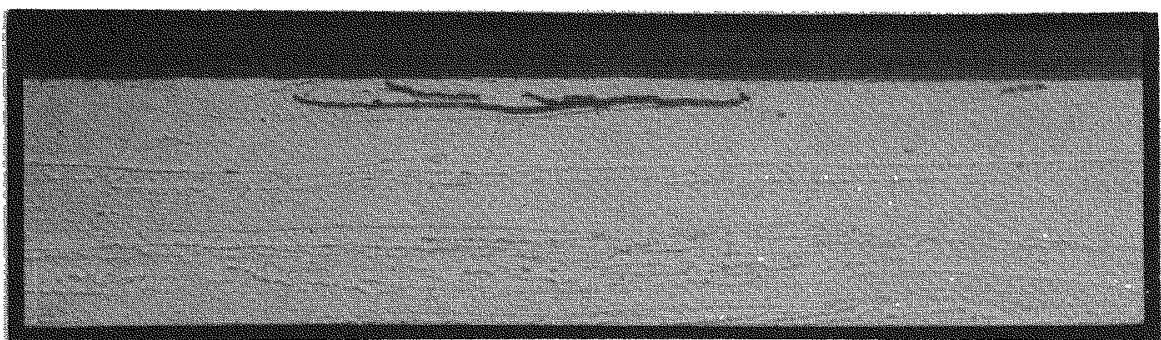

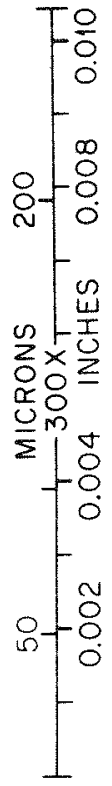
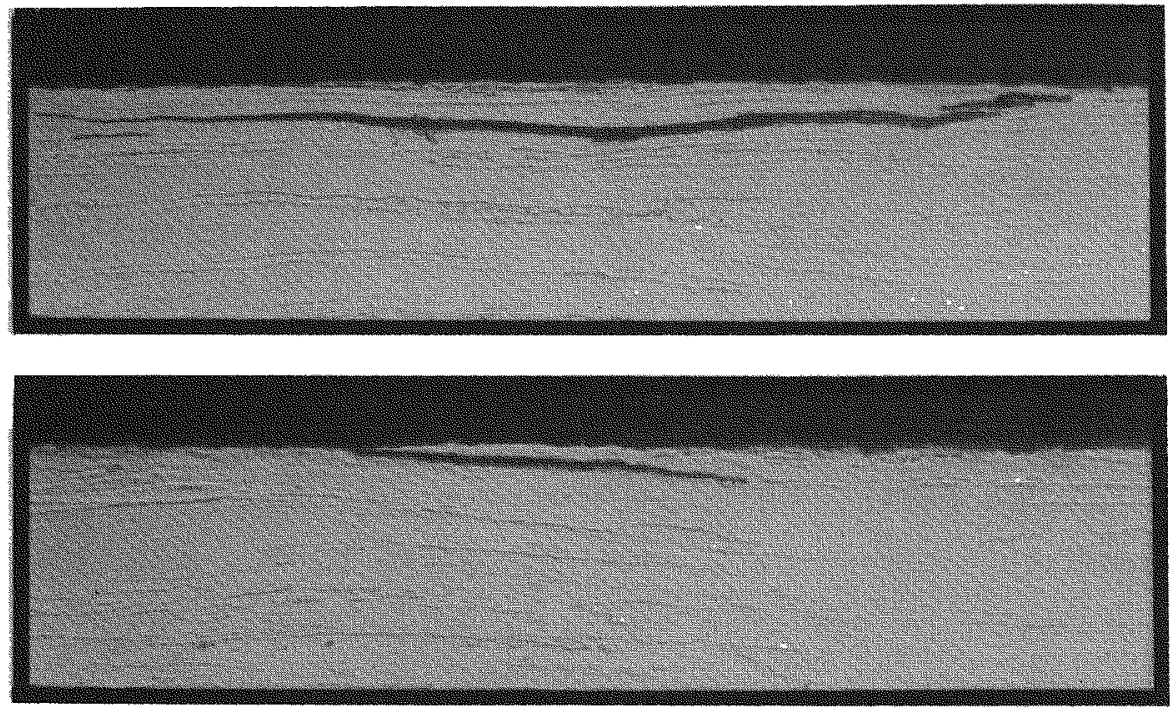

HD $428 P$

HD $429 P$

HD $430 P$
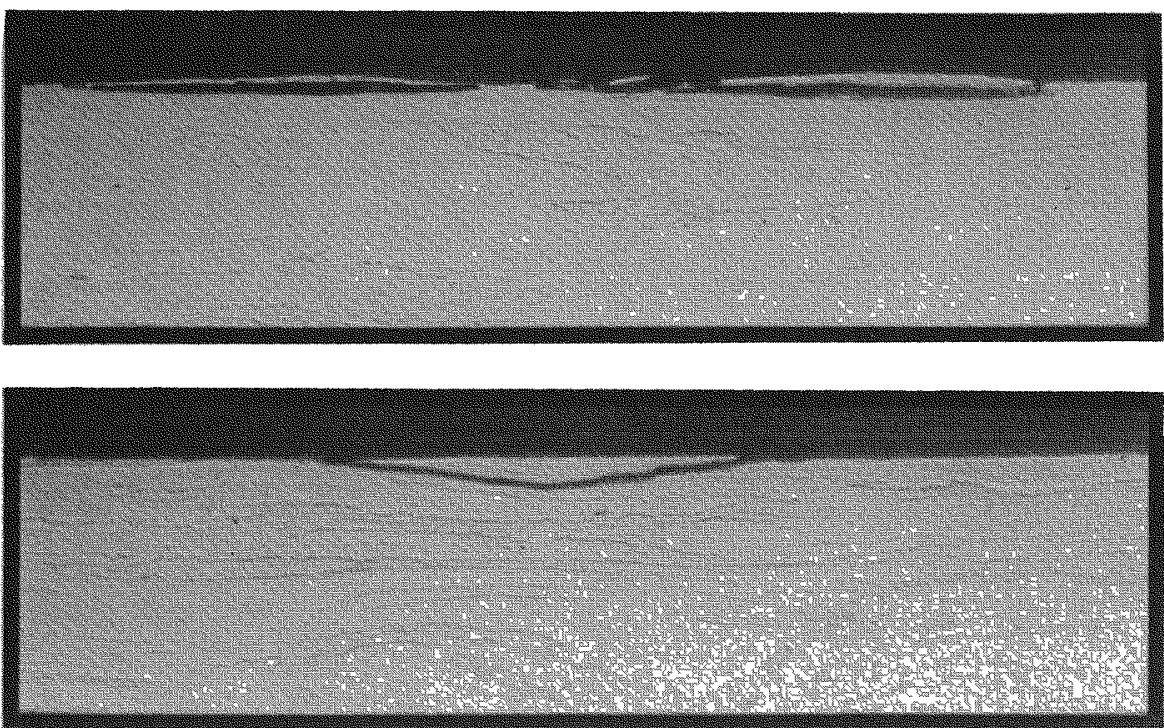

HD $432 P$

Fig. 4.1. Surface Delamination in Metallography Samples of HD 427-432. 

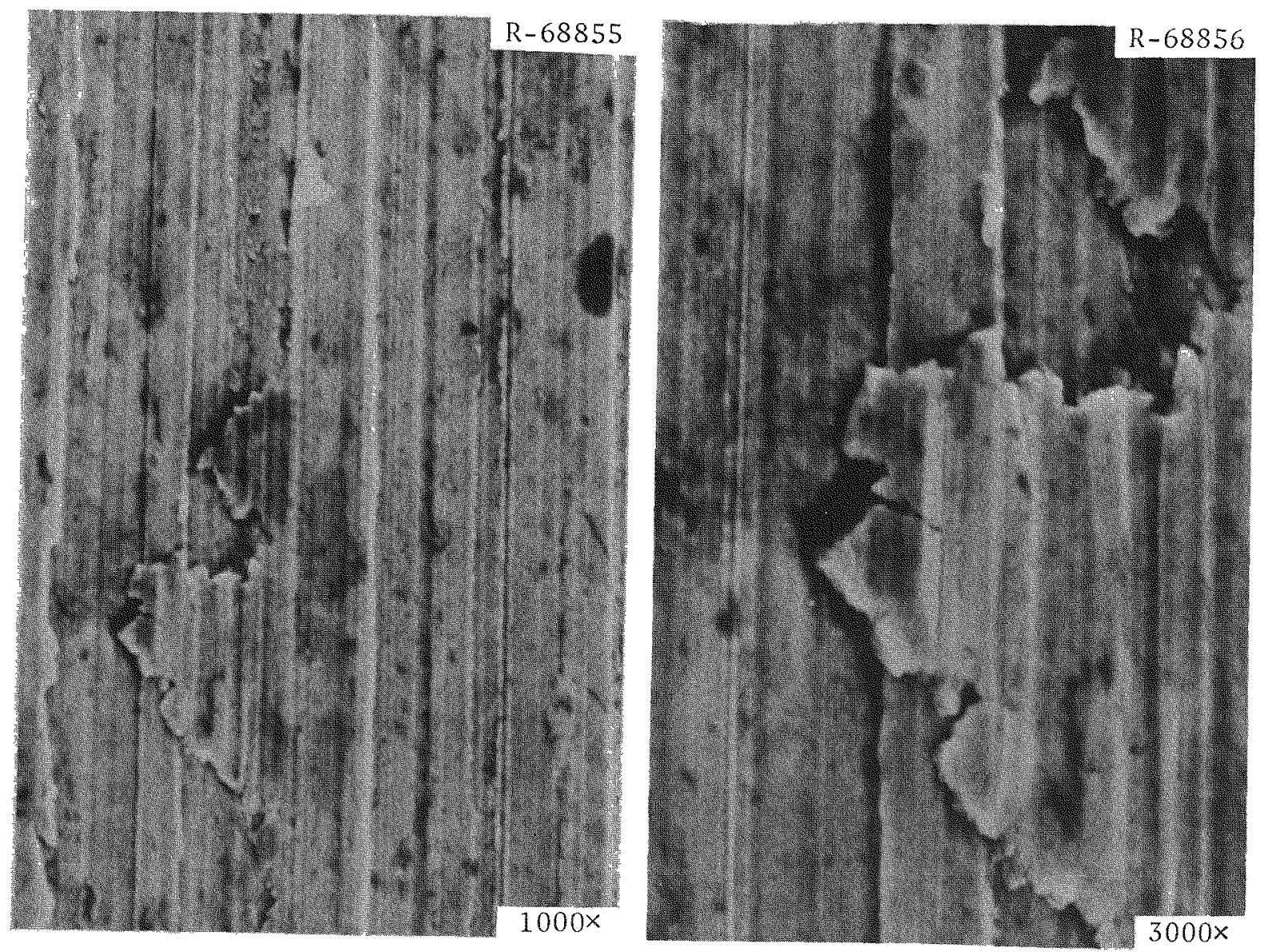

Fig. 4.2. Scanning Electron Micrographs of Ground Surface of the HD-428, \#1 Forming Disk.

There are many possible causes for the surface delaminations. The most likely and most frequently mentioned causes are listed below.

\begin{tabular}{|c|c|}
\hline $\begin{array}{l}\text { Impurities in Powder } \\
\text { Contamination of Ingots } \\
\text { Loss of Dopants }\end{array}$ & Material \\
\hline $\begin{array}{l}\text { Melting and Casting } \\
\text { Rolling } \\
\text { Annealing } \\
\text { Grinding } \\
\text { Sampling } \\
\text { Mounting/Grinding/Polishing }\end{array}$ & Procedure \\
\hline $\begin{array}{l}\text { Rolls } \\
\text { Grinding Machine } \\
\text { Grinding Wheel } \\
\text { Cutoff Saw } \\
\text { Metallographic Materials }\end{array}$ & Equipment \\
\hline
\end{tabular}


The 1ist of possible causes can be grouped into three headings: material, procedure, and equipment. In addition, statistical fluctuations and crack propagation must be considered. A crack initiated by bad procedure or equipment at one point in the fabrication process can propagate in later fabrication steps.

Some preliminary experiments were done in an attempt to find a solution to the surface delamination problem without upsetting the schedule. Higher stress-relief temperatures and a new grinding wheel did not solve the problem. We don't believe that these results can be fairly interpretted at this time because the grinding specimens used already contained surface delaminations which may have propagated during continued grinding or in the metallographic process.

In order to reduce the number of variables, an experiment was done to look at the material alone. Pieces were removed from the unground skeletons of HD-406 and -428. HD-406 was from the second lot of HD material and had been fabricated successfully without any indication of surface delaminations. The pieces were simultaneously surface ground, sampled, and prepared for metallographic examination. Each metallographic sample was about four times the size of typical production samples in order to reduce the chances of being misled by statistical fluctuations. HD-406 had three surface delaminations while HD-428 had five. So, material that had been successfully fabricated 6 months earlier now contains the same defects seen in HD 427-432 when it is fabricated today. This is a strong indication that any chemical or metallurgical difference between the lot HD 427-432 and previous lots is not the primary cause of the surface delaminations. Weaker supporting evidence is that the trace impurity levels in HD $427-432$ are not significantly different from previous lots of HD material. Also, as seen by optical microscopy, there is no microstructural difference between HD 427-432 and previous lots.

More experiments are needed to eliminate the variables that have been listed. We had originally believed that the surface delaminations had appeared during grinding, but that was based on the assumption that samp1ing and metallographic preparation did not produce or propagate the defects. We no longer believe this is a safe assumption, so we will try to isolate these operations one at a time. 
The platinum content in fabricated sheets prior to HD $427-432$ has been higher than expected. When surface delaminations became a problem in the PICS, we decided to examine our starting powder more closely. The results shown in Table 4.2 indicated that only platinum and rhodium contents were significantly varying from lot to lot. Although there is no correlation of this data with the problem of surface delaminations in HD 427-432, the data indicate that our powder blending procedure needs improvement. One suggestion is that the as-received powders be homogenized in one large blender and then immediately separated into approximately 3-kg lots for storage. Any segregation of powders occuring during storage will then be eliminated when the dopants are blended into each lot just prior to compacting.

\section{2 .2 Foil}

A total of $1900 \mathrm{~cm}^{2}$ (290 in. $\left.{ }^{2}\right)$ of $0.12-\mathrm{mm}(0.005-\mathrm{in}.) \mathrm{Ir}-0.3 \% \mathrm{~W}$ foil was shipped to MRC this quarter. Five hundred square centimeters (eighty square inches) of this foil was made primarily for development. In the past, the cold-rolled $\mathrm{Ir}-0.3 \% \mathrm{~W}$ foil shipped to MRC has been in the form of narrow strips, 20-50 mm (1-2 in.) wide, of random length. Mound Laboratory has requested that the foils be wider so that less foil is wasted in the blanking operation. Also, larger foils would help reduce our quality control costs.

When $\mathrm{Ir}-0.3 \% \mathrm{~W}$ is rolled with molybdenum covers to $0.25 \mathrm{-mm}(0.010-\mathrm{in}$. foil, the centerline is normally thicker than the edges by about $0.02 \mathrm{~mm}$ $(0.001$ in.). This thickness variation causes splitting of the foil when the foil is subsequently cold rolled, usually within the first few bare rolling passes. Narrow pieces can be bare rolled to $0.12 \mathrm{~mm}(0.005 \mathrm{in}$.) without serious splitting or cracking because the thickness variation across the width will be less than that of wide pieces.

Wider foils can be obtained if the thickness of the foil is more uniform when it enters the bare rolling process. Samples of doped and undoped $0.25-\mathrm{mm}(0.010-\mathrm{in}$.$) foil were recrystallized and then bare rolled to$ $0.12 \mathrm{~mm}(0.005 \mathrm{in.})$. It was thought that if the bare rolling was started with the foil in a dead soft condition, then the stresses, caused by rolling material of nonuniform thickness, could not build up as high as in material 
Table 4.2. Platinum and Rhodium Concentrations in HD-Series Powder and Sheet ${ }^{a}$

\begin{tabular}{|c|c|c|c|c|c|c|}
\hline \multirow{2}{*}{ Lots } & \multicolumn{2}{|c|}{$\begin{array}{c}\text { Emission } \\
\text { Spectroscopy }\end{array}$} & \multicolumn{2}{|c|}{$\begin{array}{c}\text { Spark Source } \\
\text { Mass Spectrography }\end{array}$} & \multicolumn{2}{|c|}{ Fabricated Sheet ${ }^{b}$} \\
\hline & Platinum & Rhodium & Platinum & Rhodium & Platinum & Rhodium \\
\hline $\begin{array}{l}\text { As-received, Platina-refined } \\
\text { powder }\end{array}$ & - & - & 50 & 60 & - & - \\
\hline $\mathrm{HD} \quad 400-402^{\mathrm{C}}$ & $<50$ & $<100$ & 50 & 50 & 0.8 & 15 \\
\hline HD $403-408^{C}$ & & & 500 & 50 & 25 & 30 \\
\hline HD $409-414^{C}$ & 650 & 400 & 1500 & 300 & 25 & 30 \\
\hline HD $415-420^{c}$ & & & 500 & 500 & 130 & 65 \\
\hline HD $421-426^{C}$ & & & 500 & 250 & 110 & 40 \\
\hline $\mathrm{HD} \quad 427-432^{\mathrm{C}}$ & 750 & 350 & 2000 & 250 & 60 & 25 \\
\hline HD $457-462^{c}$ & $<100$ & $<100$ & 700 & 100 & - & - \\
\hline Remaining undoped powder & & & 1000 & 700 & - & - \\
\hline
\end{tabular}

${ }^{\mathrm{a}}$ Concentrations shown in ppm.

$\mathrm{b}$ Average concentration of lot.

$\mathrm{c}_{\text {Powder blended with dopants. }}$ 
in the wrought condition. The undoped (WGR) foil delaminated badly, however, and failed the dye penetrant check. The doped (WGDR) foil rolled out well and was wider than most foils. However, MRC has reported a poor yield with this foil and metallography has revealed some apparent internal delaminations. Other foil samples were cross rolled in the bare rolling process. This allowed us to make wider foils, but their length was limited by the 250-mm- (10-in.-) wide rolling stand. The undoped (WGR) foil again delaminated badly and failed the dye penetrant check. The doped (WGDR) foil showed no delaminations either in dye penetrant or in metallography samples. MRC yield data is not available on this foil, but it appears that the crossrolled foil does not offer any advantage over the narrow longitudinallyrolled foil in terms of yield. We have since found that by judiciously trimming the foil as we bare roll it in order to prevent the buildup of high stresses that split the foil, we can produce wider pieces, typically 60-mm (2 1/2-in.) wide. About eight foils will be obtained from each ingot by using this method instead of sixteen. Our yield per ingot will be about the same, and it is expected that MRC's yield per foil will improve.

\subsection{Impact Properties of Production Material \\ C. T. Liu}

We have characterized the impact properties of $\mathrm{Ir}-0.3 \% \mathrm{~W}$ production material with or without adding DOP-4 dopants. Sheet specimens were heat treated $19 \mathrm{hr}$ at $1500^{\circ} \mathrm{C}$ and then impacted at $85 \mathrm{~m} / \mathrm{sec}(280 \mathrm{fps})$ at $1350^{\circ} \mathrm{C}$. Table 4.3 summarizes the impact data for doped (DOP-4) and undoped alloys. The preparation of these alloys is noted in the footnotes of this table. The undoped WG and WC had 9.6-10.7\% elongation and 21-23\% reduction of area at the impact conditions. All the doped material had better impact properties; however, their elongation varies from 15.2 to $26.8 \%$, and their reduction of areas vary from 39 to $60 \%$. Among the doped materials, DOP-4 $(0.3 \% \mathrm{~W})-1$ and HD-400 (prepared from $100 \%$ powder compacts) had the best impact properties, while WGD-271 and HD-416 and -428 (produced from $40 \%$ virgin compacts and $60 \%$ recycled skulls and heads through a successive electron-beam-melting process) had the worst impact properties. In regard to fracture behavior, WC and WG fractured main1y by grain-boundary separation. 
Table 4.3. Tensile Impact Properties of Ir-0.3\% W Alloy Sheet Annealed $19 \mathrm{hr}$ at $1500^{\circ} \mathrm{C}$ and Tested at

$85 \mathrm{~m} / \mathrm{sec}(280 \mathrm{fps})$ at $1350^{\circ} \mathrm{C}$

\begin{tabular}{|c|c|c|c|c|}
\hline $\begin{array}{l}\text { Heat } \\
\text { Number }\end{array}$ & $\begin{array}{l}\text { Grain } \\
\text { Size }\end{array}$ & $\underset{\left(\begin{array}{c}0 \\
0\end{array}\right)}{\text { Elongation }}$ & $\begin{array}{c}\text { Reduction } \\
\text { of Area } \\
(\%)\end{array}$ & Fracture Mode ${ }^{b}$ \\
\hline$W C-65^{c}$ & 3.4 & 9.6 & 21 & Mainly GBS \\
\hline$W G-204^{c}$ & 3.8 & 10.7 & 23 & Mainly GBS \\
\hline DOP $-4(0.3 \% W)-1^{\mathrm{d}}$ & 9.9 & 26.8 & 60 & $\mathrm{TF}$ and $\mathrm{DR}$ \\
\hline WGD $-271^{\mathrm{e}}$ & 8.4 & 18.2 & 45 & $\mathrm{TF}$ (Ma) and GBS (Mi) \\
\hline $\mathrm{HD}-400^{f}$ & 12.4 & 21.1 & 52 & Mainly $\mathrm{TF}$ \\
\hline $\begin{array}{l}H D-416^{g, h} \\
H D-416^{g, h} \\
H D-416 \text { (av) }\end{array}$ & 8.0 & $\begin{array}{l}18.1 \\
14.8 \\
16.4 \pm 2\end{array}$ & $\begin{array}{l}45 \\
36 \\
40 \pm 5\end{array}$ & $\begin{array}{l}\mathrm{TF}(\mathrm{Ma}) \text { and GBS (Mi) } \\
\mathrm{TF} \text { and GBS }\end{array}$ \\
\hline $\begin{array}{l}\mathrm{HD}-428^{g, h} \\
\mathrm{HD}-428^{g, h} \\
\mathrm{HD}-428 \text { (av) }\end{array}$ & 8.9 & $\begin{array}{l}15.2 \\
16.5 \\
15.8 \pm 2\end{array}$ & $\begin{array}{l}39 \\
42 \\
40 \pm 5\end{array}$ & $\begin{array}{l}\text { TF and GBS } \\
\text { TF (Ma) and GBS (Mi) }\end{array}$ \\
\hline
\end{tabular}

$\mathrm{a}_{\text {Number }}$ of grains across a $0.64-\mathrm{mm}$ (0.025-in.) sheet thickness.

$\mathrm{b}_{\mathrm{GBS}}=$ grain-boundary separation; $\mathrm{TF}=$ transgranular fracture;

$\mathrm{DR}=$ ductile rupture; $\mathrm{Ma}=$ major fraction; and $\mathrm{Mi}=$ minor fraction .

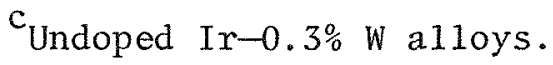

$\mathrm{d}_{\text {Ir-0.3\% }} \mathrm{W}$ a1loy doped with DOP-4 dopants, produced from electronbeam melting of WG powder compacts.

${ }^{\mathrm{e}}$ Ir-0.3\% W alloy doped with DOP-4 dopants, produced from electronbeam melting of $40 \%$ WG powder compacts and $60 \%$ WG recycled skulls and heads.

$f_{I r-0.3 \% W}$ alloy doped with DOP-4 dopants, produced from electronbeam melting of HD powder compacts.

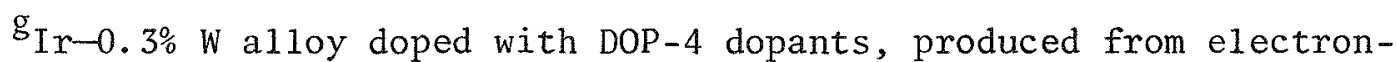
beam melting of $40 \%$ HD powder compacts and $60 \% \mathrm{HD}$ recycled skulls and heads.

$h_{\text {Duplicate tests. }}$

With an increase in ductility of the doped materials, the fracture mode changes from grain-boundary separation and transgranular fracture to transgranular fracture and ductile rupture. Table 4.3 also indicates that the production materials $\mathrm{HD}$ and $\mathrm{WGD}$, produced through a successive melting process, had grain structure coarser than that of the materials produced from $100 \%$ powder compacts. 
The results in Table 4.3 indicate that degradation of DOP-4 material occurs through the production process. This raises three critical questions: (1) What causes this degradation? (2) If degradation results from loss of dopants, which dopant element is responsible for this degradation? and (3) If the current production process continues, what are the expected (worst) impact properties of production material? The answers to these questions may be obtained from comparison of the data in Tables 4.3 and 2.1 (see p. 26 of this report). The impact properties and grain size of production material HD-428, -416 , and WGD-271 are close to those of DOP-15 doped with thorium and iron* but with no aluminum. This suggests that the low-melting element, aluminum, is lost through evaporation during successive electron-beam melting, and that the poor impact properties of production material are most probably due to loss the the aluminum dopant. Furthermore, we believe that the lowest impact elongation of the doped production material should be close to that of DOP-15 (15\% elongation after a heat treatment of $19 \mathrm{hr}$ at $1500^{\circ} \mathrm{C}$ ) and that this elongation is sufficient to survive the FSA impact test at maximum credible accident conditions.

Also note that sample HD-428 contained microscopic surface delaminations in the as-ground condition (see section 4.2 of this report), and they have no apparent effect on the tensile impact properties of that sample as compared to the other production lots having recycled feed material.

*The data indicate that doping with iron has no beneficial effect on impact properties and grain size of $\operatorname{Ir}-0.3 \% \mathrm{~W}$ alloy. 
Blank 


\section{INTERNAL DISTRIBUTION}

1. D. N. Braski

2. C. R. Brinkman

3. J. A. Carter

4. R. E. Clausing

5. J. E. Cunningham

6. J. H. DeVan

7. J.R. Distefano

8. R. G. Donnelly

9. J. I. Federer

10. G. M. Goodwin

11. J. P. Hammond

12. D. E. Harasyn

13. R. L. Heestand

14. M. R. Hill

15. H. Inouye

16. E. Lamb

17. C. T. Liu

18. M. M. Martin
19. W. R. Martin

20. R. E. McDonald

21. C. L. Ottinger

22. P. Patriarca

23. H. Postma

24-28. A. C. Schaffhauser

29. G. M. Slaughter

30. J. O. Stiegler

31. V. J. Tennery

32. D. B. Trauger

33. J.R. Weir, Jr.

34. C. L. White

35. R. 0. Williams

36-37. Centra1 Research Library

38. Document Reference Section

39-43. Laboratory Records

44. Laboratory Records, ORNL RC

45. ORNL Patent office

\section{EXTERNAL DISTRIBUTION}

46-47. AiResearch Manufacturing Company of Arizona, 402 South 36 th Street, P.O. Box 5217, Phoenix, AZ 85010

J. R. Hadley

J. E. McCormick

48-49. Batte11e Memorial Institute, 505 King Avenue, Columbus, OH 43201

C. Al exander

W. Pardue

50. Battelle's Pacific Northwest Laboratories, Battelle Blvd., Richland, WA 99352

H. Fullam

51. Cabot Corporation, Ste11ite Division, 1020 Park Avenue, Kokomo, IN 46901

J. Tackett

52. Engelhard Industries, 700 Blair Road, Carteret, $N J 07008$

H. J. Albert

53. Fairchild Space and Electronics Company, Germantown, MD 20767

A. Schock 
54. General Electric Company, P.O. Box 15132, Cincinnati, OH 45215

R. G. Frank

55. General Electric Company, Valley Forge Space Center, P.0. Box 8048, Philadelphia, PA 19101

E. W. Williams

56. Gulf Energy and Environmental Systems, P.0. Box 608, San Diego, CA 92112

N. Elsner

57. Kirtland Air Force Base, NM 87117

Directorate of Nuclear Safety

58-60. Los Alamos Scientific Laboratory, P.0. Box 1663, Los Alamos, NM 87545

R. D. Baker

S. E. Bronisz

S. Hecker

61. Minnesota Mining and Manufacturing Company, 2501 Hudson Road, St. Paul, NM 55119

E. F. Hamp I

62-63. Monsanto Research Corporation, P.0. Box 32, Miamisburg, OH 45342

W. T. Cave/D. P. Kelly

E. W. Johnson/D. L. Coffey

64-65. Savannah River Laboratory, E. L. DuPont de Nemours and Company, Aiken, SC 29801

R. Gregg

J. R. Hilley

66. Sunstrand Energy Systems, 4747 Harrison Avenue, Rockford, IL 61101

E. Kreuger

67-68. Teledyne Energy Systems, 110 W. Timonium Road, Timonium, MD 21093

W. J. Barnett

W. Osmeyer

69. USERDA Dayton Area Office, P.0. Box 66, Miamisburg, OH 45342

E. A. Walker 
70-82. USERDA Division of Nuclear Research and Applications, Washington, DC 20545
R. T. Carpenter
A. L. Mowery
T. J. Dobry
G. A. Newby
N. Goldenberg
B. J. Rock
T. J. Holleman
C. O. Tarr
W. D. Kenney
N. R. Thielke
A. P. Litman
E. J. Wahlquist
J. J. Lombardo

83. USERDA Division of Reactor Research and Development, Washington, DC 20545

J. M. Simmons

84. USERDA Oak Ridge Operations Office, P.O. Box E, Oak Ridge, TN 37830 Research and Technical Support Division

85. USERDA Office of Program Coordination and Management - Reactors and Space, 1333 Broadway, Oakland, CA 94612

W. L. Von Flue

86. USERDA Savannah River Operations Office, P.0. Box "A", Aiken, SC 29801 L. M. East

87-113. USERDA Technical Informantion Center, Office of Information Services, P.0. Box 62, Oak Ridge, TN 37830

114. USNASA Headquarters, Washington, DC 20546

T. B. Kerr

115. USNASA Jet Propulsion Laboratory, California Institute of Technology, 4800 Oak Grove Drive, Pasadena, CA 91103

V. Truscel1o

116-117. USNASA Lewis Research Center, 2100 Brookpark Road, C1eve1and, OH 44135
M. Ault
R. Migra
R. H. Titran 